Andrews University

Digital Commons @ Andrews University

2005

\title{
Building a Place of Worship: The Journey of the Downsview Seventh-day Adventist Church in Toronto
}

Kenneth Roy Campbell

Andrews University

Follow this and additional works at: https://digitalcommons.andrews.edu/dmin

Part of the Practical Theology Commons

\section{Recommended Citation}

Campbell, Kenneth Roy, "Building a Place of Worship: The Journey of the Downsview Seventh-day Adventist Church in Toronto" (2005). Professional Dissertations DMin. 692.

https://dx.doi.org/10.32597/dmin/692

https://digitalcommons.andrews.edu/dmin/692

This Project Report is brought to you for free and open access by the Graduate Research at Digital Commons @ Andrews University. It has been accepted for inclusion in Professional Dissertations DMin by an authorized administrator of Digital Commons @ Andrews University. For more information, please contact repository@andrews.edu. 


\section{ABSTRACT}

\section{BUILDING A PLACE OF WORSHIP: THE JOURNEY OF THE DOWNSVIEW SEVENTH-DAY ADVENTIST CHURCH IN TORONTO}

\section{by}

Kenneth Roy Campbell

Adviser: Clifford Jones 


\section{ABSTRACT OF GRADUATE STUDENT RESEARCH}

Dissertation

Andrews University

Seventh-day Adventist Theological Seminary

Title: BUILDING A PLACE OF WORSHIP: THE JOURNEY OF THE

DOWNSVIEW SEVENTH-DAY ADVENTIST CHURCH IN TORONTO

Name of researcher: Kenneth Roy Campbell

Name and degree of faculty adviser: Clifford Jones, D.Min., Ph.D.

Date completed: August 2005

\section{Purpose}

The purpose of this dissertation is to outline the process of constructing a new place of worship for the Downsview Seventh-day Adventist Church in Toronto, Canada. It can also serve to help other church congregations design and build appropriate places of worship.

\section{Problem}

The Downsview Church had been renting worship space for more than sixteen years. The use of rented space made fulfilling the mission of the church difficult for a variety of reasons. A new physical place of worship for the church was essential. 
Method

In this dissertation, I examine biblical and theological principles for building places of worship, focusing especially on Bible texts and the writings of Ellen G. White. I also examine current literature on the proper management of church building projects. I outline how these theoretical and practical resources were used to guide the Downsview Church construction project.

The Results

My experience in implementing the church-building model developed here has led to the identification of a set of recommendations to guide congregations undertaking building plans. These recommendations focused on both the planning of construction projects and their implementation.

\section{Conclusion}

When rooted in appropriate theological and biblical principles, church-building projects can be very effective and are, in principle, replicable. 


\title{
Andrews University \\ Seventh-day Adventist Theological Seminary
}

\section{BUILDING A PLACE OF WORSHIP: THE JOURNEY OF THE DOWNSVIEW SEVENTH-DAY ADVENTIST CHURCH IN TORONTO}

\author{
A Dissertation \\ Presented in Partial Fulfillment \\ of the Requirements for the Degree \\ Doctor of Ministry
}

by

Kenneth Roy Campbell

August 2005 


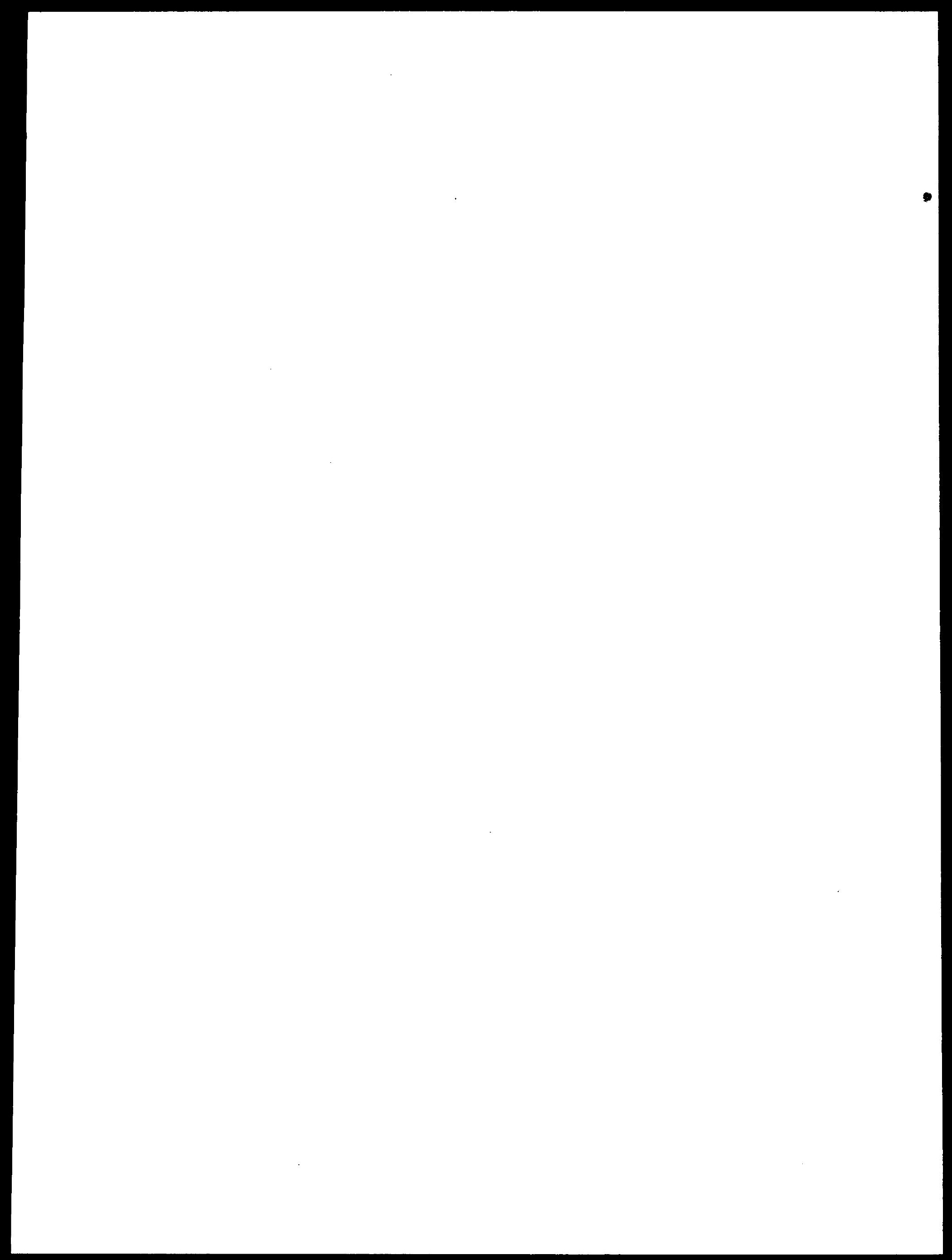




\title{
BUILDING A PLACE OF WORSHIP: THE JOURNEY OF THE DOWNSVIEW SEVENTH-DAY ADVENTIST CHURCH IN \\ TORONTO
}

\author{
A dissertation \\ presented in partial fulfillment \\ of the requirements for the degree \\ Doctor of Ministry
}

by

Kenneth Roy Campbell

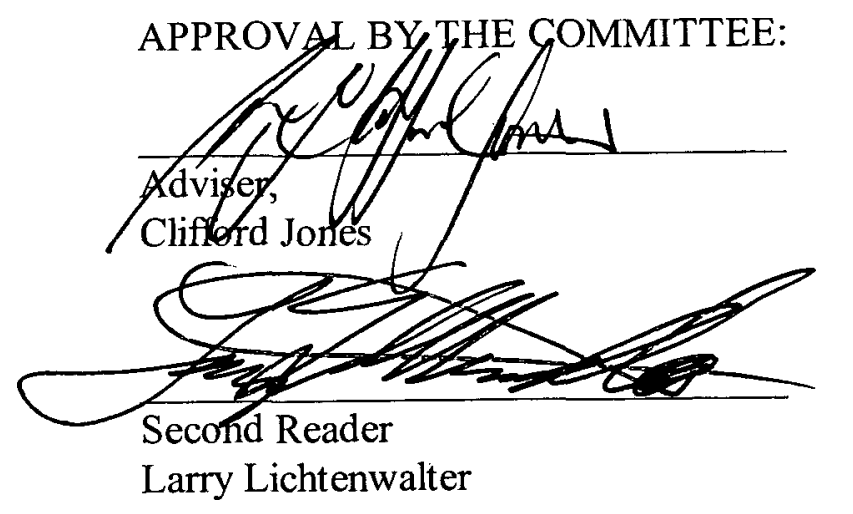

Third Reader
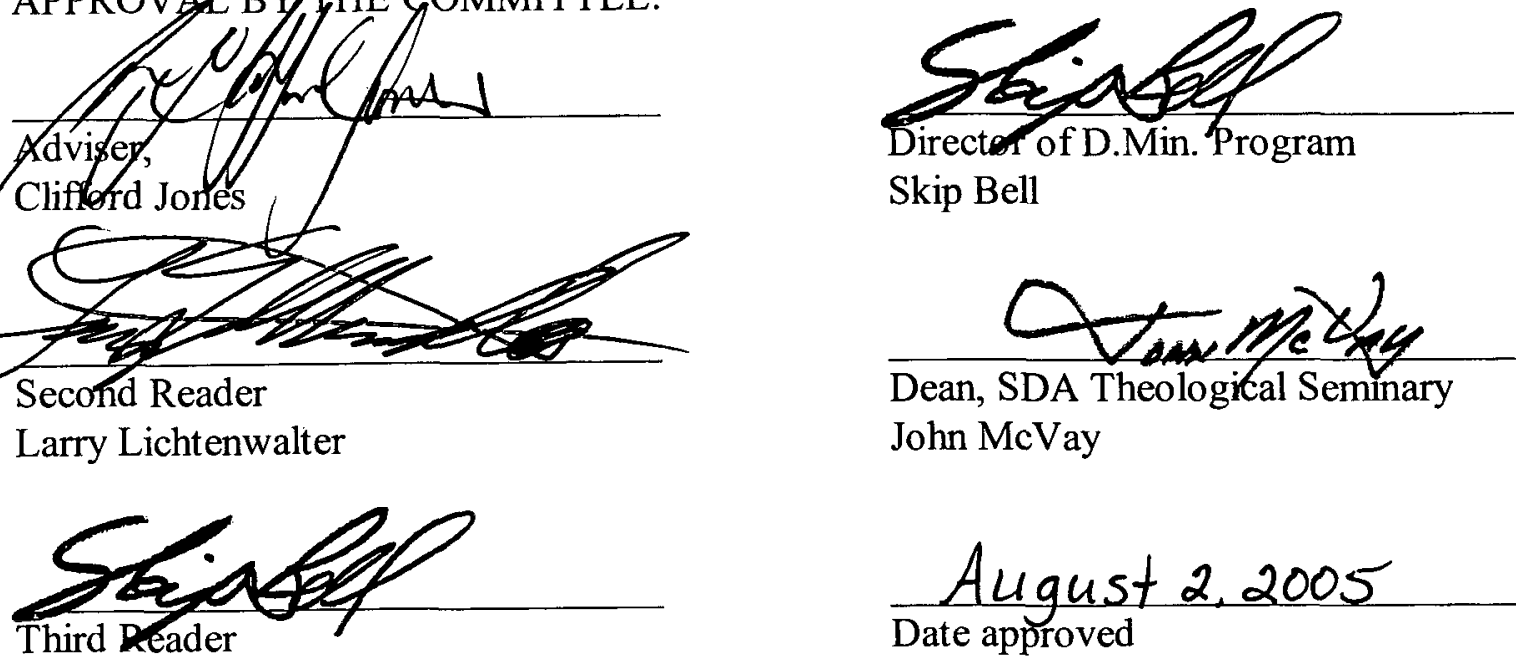

Skip Bell

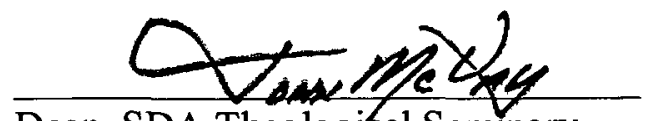

Dean, SDA Theological Seminary John McVay

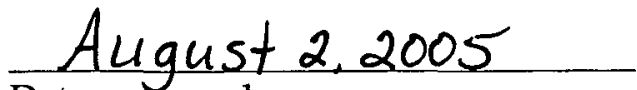
Date approved 
This dissertation is dedicated first to the glory of God, then to my wife, Velma, and my sons, Kenroy, Christopher, and Andre. 


\section{TABLE OF CONTENTS}

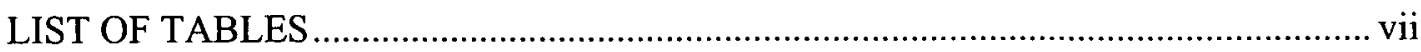

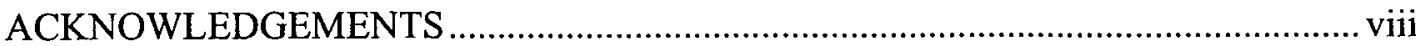

Chapter

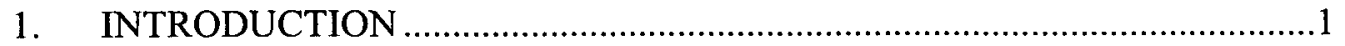

Purpose of the Dissertation ..................................................................... 1

Background to the Problem ................................................................ 1

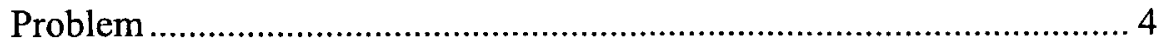

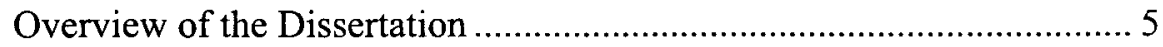

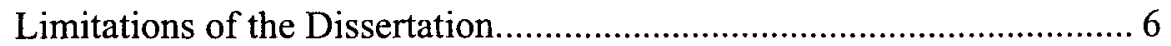

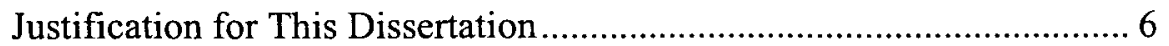

2. BIBLICAL AND THEOLOGICAL PRINCIPLES FOR CHURCH

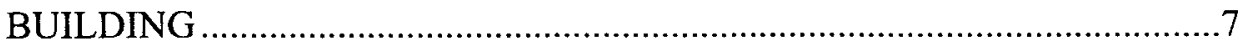

Old Testament Principles for Church Building ...................................... 7

The Building of Noah's Ark ...........................................................

The Building of the Hebrew Sanctuary ..........................................13

The Building of Solomon's Temple ..............................................22

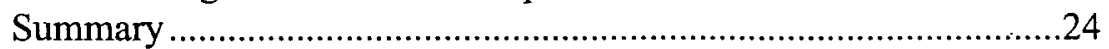

New Testament Principles for Church Building ................................... 24

Principles from Ellen G. White on Building a Place of Worship .......... 32

Summary and Conclusions ................................................................ 44

3. THE HISTORY OF THE DOWNSVIEW SEVENTH-DAY ADVENTIST CHURCH.

Geographic, Economic, and Cultural Profile of the

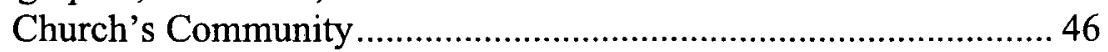

The Early Beginnings and Trends of the Church (1979 to 1994).......... 49

The Period of Church Building and Evangelism (1994-2004) .............. 54

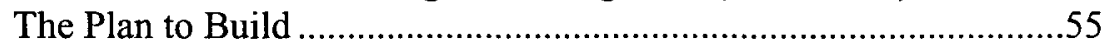

The Strategic Plan for a New Church Building .............................59

Church Growth and Evangelism............................................62

Church Building..................................................................63

Training and Equipping Church Leaders..............................63

Church Finance .................................................................69 
Communicating the Vision to Church Members ............................69

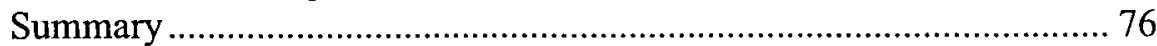

4. STRATEGIC PLAN FOR BUILDING A PLACE OF WORSHIP ................77

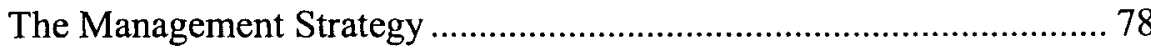

The Right Location for the Church Building ...................................... 81

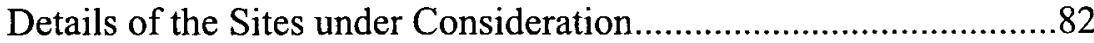

Important Issues to Consider When Selecting Location....................85

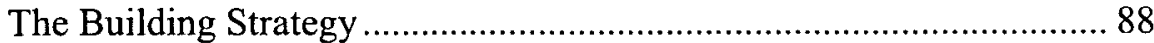

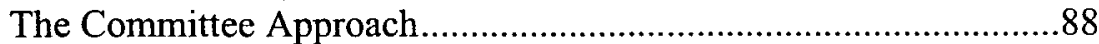

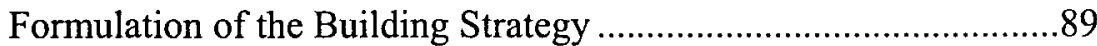

Financial Strategy for Construction of the New Sanctuary .................. 91

Building Committee Report ..........................................................992

The Experts Involved in the Building Process..................................99

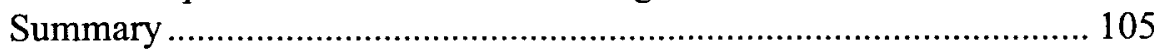

5. THE BUILDING DESIGN, PROCESS, AND COMPONENTS .................108

Overview of the Building Design ...................................................... 109

Theological Considerations ........................................................109

Designing Interior and External Space .........................................111

Deciding on Structure and Location ...........................................116

Narration of the Building Process....................................................... 118

Steps Leading to Beginning of Construction.................................118

Designing the New Sanctuary.....................................................125

Estimating the Cost of the New Building .....................................127

Launching the Project ................................................................. 128

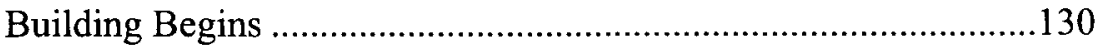

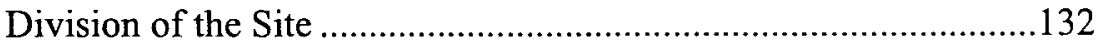

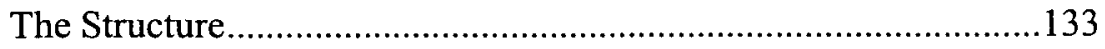

Plumbing, Drainage, Heating, Light, and Ventilation ...................136

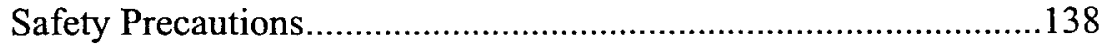

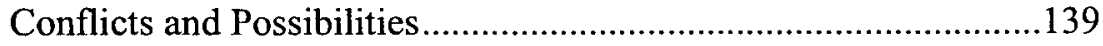

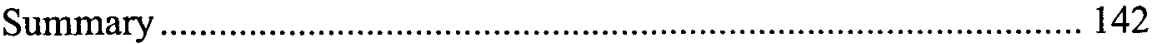

6. SUMMARY, CONCLUSIONS, AND RECOMMENDATIONS ….............144

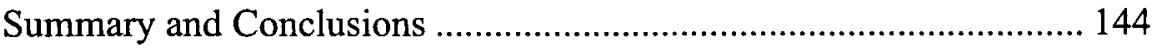

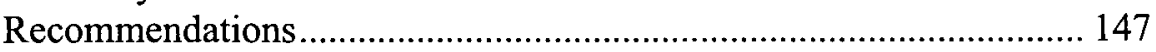

Appendix

A. PREPARATION OF THE CHURCH: AN APPEAL TO THE MEMBERS

TO BUILD A PLACE OF WORSHIP .....................................................150 
B. ESTIMATING THE COST OF THE BUILDING PROJECT: PROPOSED ESTIMATES FOR THE COST OF THE NEW BUILDING

C. A MASTER PLAN FOR BUILDING A PLACE OF WORSHIP: COMMUNICATING THE PLAN TO THE CHURCH

D. BUILDING PROCEEDURES SET OUT BY THE SEVENTH-DAY ADVENTIST CHURCH

E. PICTORAL NARRATION OF THE NEW DOWNSVIEW SEVENTH-DAY ADVENTIST CHURCH FROM THE GROUNDBREAKING TO COMPLETION (JUNE 2002 - JUNE 2003). 


\section{LIST OF TABLES}

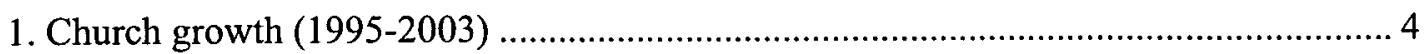

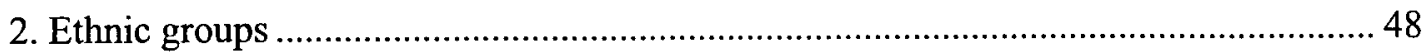

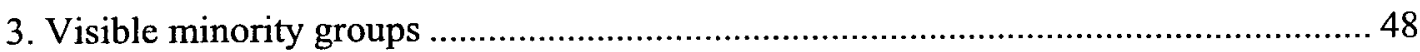

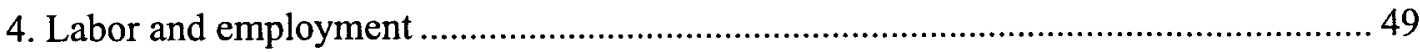

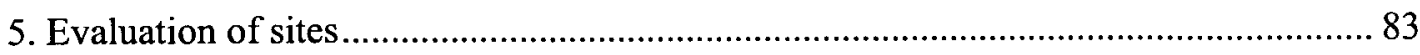

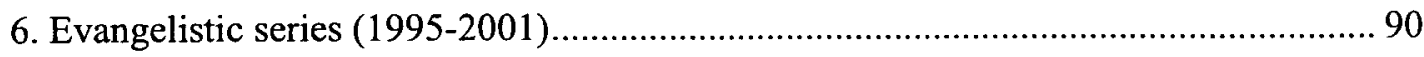

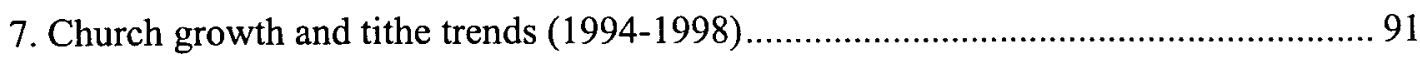

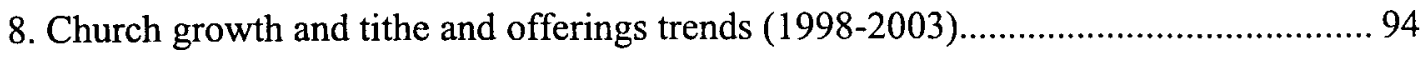

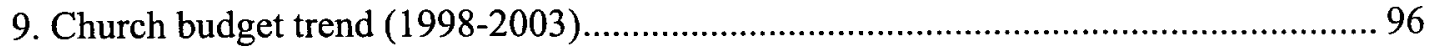




\section{ACKNOWLEDGEMENTS}

This project could not have been accomplished without the faithful support of the members of the Downsview Seventh-day Adventist Church. I would like to acknowledge the leadership of Maxine Black and the financial management of Lorna Dixons, who served as treasurer for ten years. I would also like to acknowledge the administration of the Ontario Conference: Elder Derick Nichols, president; and Elder Jacob Heibert and Elder Ulyssis Gurian, for their support and commitment to the work of the Downsview Church. I would further like to acknowledge Dr. Clifford Jones, my adviser, and Dr. Larry LitchenWalter for their support, as well as Jeanette Bryson and Annette Bryson for helping with editing. Thanks to Bonnie Proctor, the dissertation secretary, for her expert assistance. Finally, I would like to thank Rita Pusey, the Doctor of Ministry secretary for her consistent reminders with regards to timelines. 


\section{CHAPTER 1}

\section{INTRODUCTION}

\section{Purpose of the Dissertation}

When I first became pastor of the Downsview Seventh-day Adventist Church in Toronto, Canada, in 1994, there were 240 church members. By 2000, church membership had grown to over $400 .^{1}$ Membership grew despite numerous challenges. The construction of a new church building was an increasingly high priority. "A sanctuary provides a tangible aspect for the divine presence. In their humanity, God's people have a need for concreteness in their relationship with God; a purely spiritual worship is incomplete and left unrelated to body and life." ${ }^{2}$ The purpose of this dissertation is to outline the process of building a new place of worship for the Downsview Church.

\section{Background to the Problem}

When I arrived as the new pastor of the Downsview Seventh-day Adventist Church, the church's members were meeting for worship in rented facilities and had been doing so for more than fifteen years. To make it worse, upon occasion, church services

\section{'Conference Directory Statistics: 1994 (Oshawa, Ontario: The Ontario} Conference of Seventh-day Adventists); Conference Directory Statistics: 2000 (Oshawa, Ontario: The Ontario Conference of Seventh-day Adventists).

${ }^{2}$ Terrence E. Fretheim, "Exodus," Interpretation, A Bible Commentary for Teaching and Preaching (Louisville, TN: John Knox Press, 1991), 273. 
would be disrupted for the day because the host church had made other plans for the building. What made this especially disturbing — especially during the cold winter months and on rainy days--was the fact that many of the church's members, including frail and elderly ones, would have to take public transportation part of the way to church and then to walk for over a mile before arriving at their destination. After all this, the cancellation of church services was a significant problem.

The situation in the sanctuary itself was another problem. On Friday evenings, the host church would often use the space for non-religious service events. This meant that on Sabbath mornings, our members would have to come early to clean and to set up the sanctuary area for service. The smell of tobacco and alcohol frequently lingered in the air during worship service. It often required discipline to focus on the mission and worship because of the physical distractions, the unpleasant atmosphere, and the distance that members without automobiles were required to travel to get to church.

Despite the many challenges and lack of appropriate space for worship, the church has grown significantly by baptism since it was organized in March 1979. As positive as this has been, however, the congregation's growth made it increasingly difficult to find space to lease. Few churches wanted to lease worship space to such a large group of people. Additionally, the cost of renting space was escalating. Eventually, changes in location and the condition of rented space began to negatively influence the membership. Because of the constant uncertainty over worship space, members began transferring to other Adventist churches, and attracting new members became a challenge. 
Another problem I found when I was assigned to the church was a general lack of motivation to meet the long-term goals of the church. It was essential that we find or build our own sanctuary. The cost of property was escalating in the Toronto area, however. The cost of construction for new buildings and vacant lands was rising every year. If the church was unable to find a permanent place for worship, members of the congregation realized that the problem would be greater in the future. One of the greatest obstacles to this project was the difficulty of raising sufficient funds.

In 1995, the church purchased an industrial site with an old building, which could be converted into a place of worship. Since not having a specific place for worship leads to a lack of discipline in the plans and programs for the church, the decision was made to use this building as a starter home until sufficient funds were raised to construct a new place for worship. Church members worked together to renovate the industrial building located on the site as the new sanctuary. Although space was limited at best, the inspiration of owning and looking forward to a larger and better place gave the believers new inspiration and new determination to construct a permanent place for worship.

To achieve the goal of constructing a new place of worship, the congregation needed to find new ways of preventing the loss of new and old members. A new evangelistic strategy helped lead to a new increase in membership. The first tent evangelistic series after I became pastor of the church, held in July 1996, resulted in 96 baptisms. This was followed by four other successful series. One in 1997 led to 107 baptisms. In 1998, a satellite series resulted in 15 more baptisms. In 1999, there was another tent series with 107 baptisms. In 2001, there were 113 baptisms (see table 1). 
New members provided a source of more money to help with the financing of the new building. As positive as it was to see the growth of the church, one year after the church relocated to the new site, a new problem developed. Overcrowded space led to a reduction in the church's growth rate. The church had simply not been able to accommodate all those who wished to join it. A larger, permanent location was vital. The construction project was launched, and in June 2003, the Downsview Church members began meeting in their newly built sanctuary.

\section{TABLE 1}

\section{CHURCH GROWTH (1995-2003)}

\begin{tabular}{llr}
\hline Year & Evangelistic Series & Baptisms \\
\hline 1995 & Reach out for Life & 35 \\
1996 & Search for Truth & 96 \\
1997 & Victory in Jesus & 107 \\
1998 & Net '98 & 5 \\
1999 & Footprints of Jesus & 105 \\
2000 & Midnight Cry & 7 \\
2001 & Amazing Love & 109 \\
2003 & Jesus is the Answer & 103 \\
\hline
\end{tabular}

\section{Problem}

The problem I address in this dissertation is twofold:

1. The church needed a new place of worship, and various practical challenges needed to be overcome for it to find a new location and build a church. I sought to explore appropriate ways of meeting these challenges.

2. Churches that seek to erect new buildings must act in accordance with appropriate theological and management principles. This project has sought to identify 
these principles and test them in relation to the Downsview Seventh-day Adventist Church's experience.

\section{Overview of the Dissertation}

In chapter 2, I explore biblical and theological principles in order to provide a theoretical foundation for the identification and construction of an appropriate place of worship for the church. I review and gain guidance from the writings of Ellen G. White, at the same time noting their consonance with contemporary best practices in the areas of fiscal, financial, and building management.

In chapter 3, I relate the history of the Downsview Church congregation and place the church in its geographic, economic, and cultural context. I seek to show how the church began and how it has accomplished its work over the years. I also outline the vision, the trends, and how the new vision for church building and church growth was communicated to the congregation. In this context, I provide an overview of selecting the various committees and the financing of the project.

In chapter 4, I examine the overall strategic plan for designing and constructing the Downsview Church building. This includes looking at the management, building, and financial strategies. I explore issues related to location of the site, with particular attention to the issue of community accessibility. I also review the church's future needs in order to determine appropriate size constraints for a new church building.

In chapter 5 , I offer a narrative of the building project, along with a construction schedule. I give an in-depth account of the building design, explain the process of putting it all together, and detail the components used in constructing the church building, in addition to considering a range of issues related to the construction process. 
In chapter 6,1 offer a summary, with conclusions and recommendations.

\section{Limitations of the Dissertation}

This dissertation presents a qualitative study of the experiences of a single congregation. While the experiences of the Downsview Church are clearly replicable, anyone generalizing from these must be careful. It is important to be aware of the specific features of that church and not assume that every aspect of the experiences of building the church for this congregation will be evident in the experiences of another congregation engaged in a church-building project.

\section{Justification for This Dissertation}

This dissertation performs several important functions.

1. It identifies biblical and theological principles relevant to the selection and construction of places of worship.

2. It assists church members as they seek to make decisions regarding the acquisition or construction of places of worship, especially in the metropolitan Toronto area of the Ontario Conference of Seventh-day Adventists.

3. It should help other pastors and church leaders design and build appropriate places of worship for their congregations. 


\section{CHAPTER 2}

\section{BIBLICAL AND THEOLOGICAL PRINCIPLES FOR CHURCH}

\section{BUILDING}

The first step in the process of this research project was to turn to the Scriptures to find the blueprint for the building of a sanctuary. This chapter focuses on the biblical and theological principles that provided the theoretical foundation for the design and building of an appropriate place of worship for the Downsview Seventh-day Adventist Church. This chapter begins with a look at several occurrences of this theme in the Old Testament followed by a look at the theme as it appears in the New Testament.

\section{Old Testament Principles for Church Building}

The theme of setting up or building a place of worship appears a number of times in the Old Testament Scriptures. In this section, three texts in which God is seen seeking to provide a place of refuge and to establish a place for teaching and instructing his people are explored. First, I look at Gen 6:13-22, which shows God instructing Noah to build an ark as a place of refuge for his faithful people. Noah's fulfillment of that task provides a model for us today as we seek to construct places of worship. Next, I explore Exod 25:8, 9, 40, which discusses Moses building the Sanctuary as a dwelling place for God. Finally, I look at King David's plan to build the Temple for God, found in $1 \mathrm{Chr} 22$, which helps us understand the importance of restoring order out of chaos. 
The Building of Noah's Ark

From the story of Noah building the Ark in response to God's command emerge important theological principles that can guide us through the process of constructing a place of worship. The flood story provides a picture of simple obedience to God's command, of trust in the divine provisions, and commitment to God in the midst of a world filled with evil.

We find in Gen 6:5 and 12 a picture of the situation to which God was responding. In vs. 5: "And God saw that the wickedness of man was great in the earth, and that every imagination of the thoughts of his heart was only evil continually." In vs. 12 God is looking upon the earth and responding to it: "And God looked upon the earth, and behold it was corrupt; for all flesh had corrupted his ways upon the earth." God then tells Noah of his planned response to the situation in vs. 13: "And God said unto Noah, 'The end of all flesh is come before me; for the earth is filled with violence through them; and, behold, I will destroy them with the earth"' (Gen 6:11-13). Not all people would inevitably meet with destruction, however. At this point, God instructed Noah to build an ark for the salvation of his people. In Gen 6:14, God explains why he must destroy the earth and begins his specific instructions for the construction of that first refuge building:

And God said unto Noah, the end of all flesh is come before me; for the earth is filled with violence through them; and, behold, I will destroy them with the earth. Make thee an ark of gopher wood; rooms shalt thou make in the ark, and shalt pitch it within and without with pitch.

God explained to Noah that his plan was to wash the world with floodwaters that would "destroy all flesh in which is the breath of life, from under heaven," telling Noah that "everything that is under the earth shall perish" (Gen 6:17), everything and everyone except for this people. Here, in vs. 18, God made his covenant with Noah: "But I will 
establish my covenant with you; and you shall enter the ark-you and your sons and your wife, and your sons wives with you." God's plan today is the same as it was in Noah's day. His plan is to save all his people.

It might be no easy task to prepare a place of worship that will provide a protected environment for teaching and preaching the word of God to people, a place that represents God's modern ark of safety, but it is a most urgent task. And it is a task that must be approached with care and dedication. The task entails constructing a place that will symbolize divine mercy to the community. Here, Noah's response to being called to action provides us with a useful model for our own behavior.

In Gen 2:22, we find that "Noah did everything just as God commanded him" (NIV). This should be the model for all who work for God today. Just as Noah "showed no hesitancy in obeying God," ' neither should we. We should do this not only for our own sakes but also for the sake of others with whom we interact. Noah "lived out the message he preached, and those who knew him best, his own family, could not avoid his holy influence." He moved by faith at the command of God, and he worked with diligence, always believing in God. As a result, when his work was done, "the Lord said to Noah, enter the ark, you and all your household; for you alone I have seen to be righteous before me in this time" (Gen 7:1).

Just like Noah, who had never seen or heard of a flood, took God's word and worked meticulously in carrying out the instructions given to him by God, so should we

'Ellen G. White, "Genesis," SDA Bible Commentary, ed. F.D. Nichols (Washington, DC: Review and Herald Publishing Association, 1960), 1:257.

${ }^{2}$ Ibid. 
follow God's plans. In Luke 17:26, Jesus gives us a message: “And as it was in the days of Noah, so shall it be in the days of the Son of man." The righteous life of Noah in the midst of a world that was terrorized by evil people is a model of the piety, persistence, and commitment that is needed today to build a place of worship for God.

The truly righteous are willing to risk themselves in faith during great peril. In spite of crime, they reach out to the needy. In spite of giants, they do good and accept weakness as their posture. Of course, the righteous in themselves are unable to stop the rapid and progressive pervasiveness and hardening of sin, as in the line of Cain and in the human situation at the time of the flood. Saints need the empowering of the Holy Spirit to reverse the tide.'

We need the same spirit and attitude of Noah today to do the work that must be done. The work of God in building a place of worship for the members of the Downsview Church required Noah-like faith and courage.

Noah's obedience is a model of perseverance for the Church today. His perseverance was the most wonderful ever heard of in the history of our world. How much trouble he must have had in getting the right kind of wood with which to build the Ark! And when the wood was found, how much trouble he must have had in getting the right sort of workmen to carry on the building. ${ }^{2}$

When God asked Noah to build this ark, it is clear that he had a clearly defined

plan. David Cotter offers an interesting response to the idea of God's plan:

In the instructions and subsequent building of the ark there is already a beginning of God's reconstruction. The microcosm is ordered exactly as God wants it to be. Corrupted creation is outside, within, all is as it should be for obedient creatures. At the same time, God tells Noah both his plans for the total ruination of all the already ruined earthly life (V.17) and His plans for restoration (V.18). ${ }^{3}$

${ }^{1}$ Bruce K. Waltke and Cathi J. Fredricks, Genesis (Grand Rapids, MI: Zondervan Publishing, 2001), 120.

${ }^{2}$ Joseph S. Exell, The Biblical Illustrator, 57 vols. (Grand Rapids, MI: Baker Book House, 1954), 1:433.

${ }^{3}$ David W. Cotter, Genesis (Collegeville, MN: Liturgical Press, 2003), 55. 
Not only was God's plan one that was well-formulated, but he articulated all the details to Noah, giving him instructions to build the ark according to a very specific design. This was a building that was designed as a refuge for his people, and God was very particular about all the details of the building project. God gave Noah instructions regarding the rooms, windows, and doors, with upper and lower stories. The plan called for specific dimensions, detailing the required length, width, and height (outlined in Gen $6: 15,16)$. Just like the ark, the church must be built according to a clearly outlined plan. The church must have features similar to those of the ark, providing suitable places for various functions. It must be designed with available space for children, access for the handicapped, rooms for parents, and rooms for the aged and the sick. It must have rooms for teaching and preaching. It must have windows for ventilation and doors for entrances and exits. The space must be designed to meet the needs of various groups of people. Just like the responsibility Noah had, we too have the responsibility of warning the inhabitants of the earth of the impending crisis. The church building must be designed with access for everyone, so that none can say that they could not come to hear the word of God.

During the entire building process, Noah's work provided a visible testimony of God and the impending judgment. Throughout the time that he worked on building the ark, Noah preached the gospel to the people. For more than one hundred years, he preached God's message, warning of impending judgment while the construction of the ark continued.

God determined to purify the world by a flood; but in mercy and love He gave the antediluvian a probation of one hundred and twenty years. During this time, while the 
ark was [being built], the voices of Noah, Methuselah, and many others were heard in warning and entreaty, and every blow struck on the ark was a warning message. ${ }^{1}$

Noah sought out volunteers to work on the building of the structure. Those who responded and worked with Noah in the building of the ark, as well as all who came into contact with the building, could hear and see the reality of God's plan for the world. “Even if [Noah's] words had not been many, the building of the Ark as such was a thundering testimony to a godless age, as Hebrew 11:7 says; through which ('building of the Ark') he condemned the world."2

This is a message that is relevant to us today. During the building of a place for worship, every effort must be made to make sure that all involved in the process whether in a direct or indirect way understand the purpose for the building. If the purpose for the building is always clear, the physical structure will stand as a witness against those who reject the preaching of the word. It will in turn be a symbol of hope to those who embrace the word.

Those involved with building a church must always be aware that controversy will almost inevitably be a part of the project. In Luke 17:26 we read: "As it was in the days of Noah, so shall it be also in the days of the son of man." Controversy will always surround the work of God. In the days of Noah, many people did not understand the work that was being undertaken. Despite the fact that the structure was being built at the command of God, "there can be little doubt that Noah was subject to much ridicule with

${ }^{1}$ Ellen G. White, "Genesis," SDA Bible Commentary, 1:1088.

${ }^{2}$ H.C. Leupold, Exposition of Genesis, 9 vols. (Grand Rapids, MI: Baker Book House, 1953), 1:279. 
respect to his venture of faith." Some people who were opposed to the work went about their business as usual. Others openly scoffed at the work. Most likely, some who worked with him did not agree with everything he was doing. Some people were critical of the work, others thought it was unnecessary or too expensive, and still others thought that they had better ideas about how the task should be accomplished.

It is important to keep in mind that when building a place of worship, not everyone will agree with the plans. Some will be in opposition to the plans. Members of the church may disagree on many issues. Some may even transfer membership because of disagreement; nevertheless, just as happened in the case of Noah, God's work will go forward regardless of opposition.

The Building of the Hebrew Sanctuary

The building of the Hebrew sanctuary, as described in Exodus, offers us another scriptural model for the building of a church. Like the ark built by Noah, the sanctuary offers an object lesson for all times. In Ex 25:8, God commands its construction: "Let them make me a sanctuary that I may dwell among them." Moses oversaw the building construction, which, with its furniture, sacrificial services, priesthood and rituals, was to be the dwelling place for God on earth. It was also one of the most graphic representations of God's character. The sanctuary was designed to point to Jesus Christ as our mediator in the final judgment. The God who designed the sanctuary wanted to reveal himself more completely to mankind, as the psalmist declares, "Thy way, O God, is in the sanctuary" (Ps 77:13).

${ }^{1}$ Genesis, Bible Study Commentary, ed. G. Charles Alder (Grand Rapids MI: Zondervan Publishing House, 1981), 1:167. 
The sanctuary building itself gave evidence of God's presence. According to D. Guthrie, “It was a 'dwelling' to represent God's co-dwelling with His people; a tent of meeting to express the truth that God does meet His people and reveal Himself to them."' This continuous presence of God was visible through the pillar of cloud by day and the pillar of fire by night. A well-designed church building on earth can help give evidence of God's presence on earth, through the preaching of His word and through the presence of the Holy Spirit living in the heart of believers. Furthermore, although God clearly cannot be confined to a particular building, a church built according to the principles of the Hebrew sanctuary can teach some designated truth about Jesus. The Hebrew sanctuary was built to the glory of God and, as Robert Boyd explains, to teach certain divine truths about the character of God:

For Israel, the tabernacle was instituted for the purpose of revealing through object lessons God's plan of redemption for every believing Israelite. Every part of the tabernacle and all its appointed ministries were to Israel a symbol, a testimony of the coming Messiah and His blessed work of redemption. ${ }^{2}$

The sanctuary was a place of revelation, a place of God's abiding presence. It was the place where God chose to meet with his people and to display his character so that his people could have a better understanding of him. Writing about the sanctuary, Roy Adams suggests that the "basic underlying idea ... was that the ritual of the tabernacle,

${ }^{1}$ D. Guthrie, The Eerdmans Bible Commentary, $3^{\text {rd }}$ ed. (Grand Rapids, MI: Wm. B. Eerdmans Publishing Company, 1970), 134.

${ }^{2}$ Robert T. Boyd, Word's Bible Handbook (Iowa Falls, IA: Word Bible Publishers, 1991), 57. 
both in its daily and yearly aspects, should serve as 'prophesies,' symbols, types, of God's cosmic plan for human salvation and the security of the universe."'

As had been the case with Noah's ark, God was the designer of the Hebrew sanctuary. God was the master architect for the building. He gave directly to Moses, as he had done before to Noah, all the instructions for the building of the sanctuary. In Exod 25:9, God speaks to Moses on the mountain saying, "According to all that I shew thee, after the pattern of the tabernacle, and the pattern of all the instruments thereof, even so shall ye make it." In vs. 40 he reiterates the point that it must be built according to his plans: "And look that thou make it then after their pattern, which was showed thee in the mount." In Exod 26:30, we read that yet again God gave Moses these same instructions: "And thou shalt rear up the tabernacle according to the fashion thereof which was showed thee in the mount."

That God would call Moses and give the same instructions several times over underscores the great importance God places upon building a place for His dwelling. Such building should not be taken lightly, but should be built with great care.

Just what kind of master plan was given by God to Moses has been fodder for much scholarly debate and disagreement. The question is whether this plan was literal or spiritual. Frank E. Gaebelein argues that God gave Moses a model or pattern:

The most important word about the Sanctuary was that it was to be built according to the "pattern" God would show to Moses. The word "pattern" comes

\footnotetext{
${ }^{1}$ Roy Adams, The Sanctuary, Understanding the Heart of Adventist Theology (Hagerstown, MD: Review and Herald Publishing Association, 1993), 58.
} 
from the verb banah (to build). This word signals the fact that typology is present, for this is only a "model" or "pattern" of the real thing.'

In the process of working on his 1981 doctoral dissertation, Richard Davidson conducted an extensive study on the nature of biblical typology. Based on his research, he concludes that, in the building of the sanctuary, Moses was "provided with a miniature model as a pattern to copy in constructing the earthly"2 one. Adams's thoughts on the matter imply that the plan was more spiritual.

It is clear that God has a special interest in the physical place of worship for his people. In the case of the Hebrew sanctuary, he had intended that the structure should serve as a model or symbol of the spiritual as well as the physical manifestation of his Divine grace. Many truths related to the salvation of mankind were taught in the sanctuary. We should keep these ideas in mind today as we construct dwelling places for his worship. God's dwelling place should be built according to the principles and plans that he laid out for us in his word.

The construction of a church entails engaging skilled labor. God did not choose angels to build the Hebrew sanctuary. Neither did he choose inexperienced persons. He chose volunteers with skillful hands to do the work. God instructed Moses to chose the right people with the right skills to do the work, people with willing hearts (Exod 25:2; 35:4-29; 36:2-7). As soon as Moses received the instructions from God, he mobilized the people to do the work. Exod 35:1 reads, "And Moses gathered all the congregation of the

${ }^{1}$ Frank E. Gaebelein, The Expositor's Bible Commentary, 12 vols. (Grand Rapids MI: Regency Reference Library, Zondervan Publishing Association, 1990), 2:453.

${ }^{2}$ Richard M. Davidson, Typology in Scripture (Berried Springs, MI: Andrews University Press, 1981), 378, 385. 
children of Israel together, and said unto them, these are the words which the Lord hath commanded, that ye should do them." Moses selected from among the people craftsmen who were skilled in woodwork and stone cutting and other forms of crafts, as demonstrated in Exod 35:30-33:

And Moses said unto the children of Israel, see, the Lord has called by name Bezalel the son of Uri, the son of Hur, of the tribe of Judah;

And he has filled him with the spirit of God., in wisdom, in understanding, and in knowledge, and in all manner workmanship;

And to devise curious works, to work in gold, and in silver, and in brass.

And in the cutting of stones, to set them, and in carving of wood, to make any manner of cunning work.

In Exod 38:21-23, we read that the people worked together and "made all that the Lord [had] commanded Moses. And with him was Aholiab, son of Ahisamach, of the Dan, an engraver, and a cunning workman, and an embroiderer in blue, and in purple, and in scarlet, and in fine linen."

Moses recognized that he could not do the work alone, so he delegated the work to people with special skills. He recognized that God has given to every person in the church a certain measure of wisdom and skill to do the work. As it was in the day of Moses, so it is today. In every church, there are people with individual trades and skills. God has put these people there to do his work. People in the church with the right skills should be chosen to work for God. These people must have the spiritual commitment along with the proper experience before they are put to work for the building of the house of God. (Naturally, when certain skills are required that cannot be found among the members of the church, it is then necessary to find those skills outside the church.) Many people, both church members and non-members alike, are willing and anxious to be part of the work for God. God will always work through those who have willing hearts and make themselves available to the Holy Spirit. In her book, How to 
Mobilize Church Volunteers, Marlene Wilson lists eight reasons why people want to volunteer.

(1) They want to be needed. (2) They want to help others and make a difference. (3) They want to learn skills or use skills they already have. (4) They want to belong to a caring community and feel accepted as members. (4) They want self-esteem and affirmation. (6) They want to grow in their faith and share their God-given gifts. (7) They want to keep from being lonely. (8) They want to support causes they believe in. ${ }^{1}$

If people are given the right opportunities, they will come forward to take part in the work for God. In Moses' day, the people considered it a great accomplishment of theirs when the building of the sanctuary was complete. "And Moses did look upon all the work, and behold, they had done it as the Lord had commanded, even so had they done it: and Moses blessed the people" (Exod 39:32, 43).

Just as in the days of Moses, all the people with their varied skills working together, in accordance with the plan, made the work possible, so it is today. Working together in building the house of God can bring blessing and unity to believers. The work of God can bring complete satisfaction to the members of the church who cooperate with the plan.

Another lesson we can draw from the building of the Hebrew sanctuary is the example provided by the type of material used in its construction. Only the best quality was used to build the sanctuary. In fact, God told Moses the exact type of material that he was to use in the construction.

And this is the contribution that you are to raise from them, gold, silver, and bronze. Blue, purple, and scarlet material, fine linen, goat hair, ram skin dyed red, porpoise skins, acacia wood, oil for lightening, spices for the anointing oil and for the

${ }^{1}$ Marlene Wilson, How to Mobilize Church Volunteers (Minneapolis, MN: Augsburg Publishing House, 1983), 87. 
fragrant incense, onyx stones and setting stones, for the ephod and for the breast piece. $^{1}$

God chose the most precious materials for the construction of the place of worship. God must also require the best possible from his people today. As one writer puts it.

Generally, the most precious materials and the best workmanship are applied to the ark of the covenant and the holy of holies, the heart of the sanctuary. . . Two principles seem to be simultaneously at work. First, only the best is good enough for God. Second, God wants to be worshipped through the material means that sustain the people's everyday life. ${ }^{2}$

A further lesson we can draw from the Hebrew sanctuary stems from the constancy of its use. Rather than being used for a once-a-week service, the sanctuary was used for services continuously. Day after day, morning to evening services were made to God. Sacrifices were offered without ceasing. People came to the sanctuary day and night to offer sacrifices. This was in accordance with God's instructions: "Now this is that which thou shalt offer, two lambs of the first year day by day continually. The one lamb thou shalt offer in the morning; and the other lamb thou shalt offer in the evening" (Exod $29: 38,39)$.

These regular services taught the believers to present themselves to God on a daily basis. The sacrifice for sin was to be continual. Anyone who sinned and could not immediately come to the tabernacle was covered by the continual sacrifice until he brought his own offering. The services were for those who lived long distances from the tabernacle or even those who could not leave work to go straight to the tabernacle every

'Exod 25: 3-7 (NASB).

${ }^{2}$ Waldemar Janzen, "Exodus," Believers Church Bible Commentary (Waterloo, Ontario: Herald Press, 2000), 336. 
time they sinned. "The daily burnt offerings were placed on the altar, but over a slow fire so that one sacrifice would last until the next one was put on. The evening sacrifice lasted until morning, and the morning sacrifice until evening."'

These sacrifices taught the people a very valuable lesson. They learned that at any time, day or night, repentant sinners could look in faith to the merits of Christ's sacrifice and receive forgiveness. The grace of God demanded that each person consecrate his or her life to the service of God. Having regular times for prayer and worship helps believers to develop a disciplined life in continually uniting their hearts to God. We read in Isa 56:7: "Their burnt offering and their sacrifices shall be accepted upon mine altar; for mine house shall be called an house of Prayer for all people.” God is never too busy to hear our prayers or accept our worship and praise.

The building of the sanctuary was funded by sacrificial offerings. Money was raised through these offerings from every believer. God had commanded from Moses to "Speak to the children of Israel, that they bring me an offering: of every man that giveth it willingly with his heart ye shall take my offering" (Exod 25:2). When Moses made this appeal to the congregation, the people responded enthusiastically, and the result was very inspiring. Their hearts were so stirred that they ended up giving even more than was needed to build the sanctuary. "The children of Israel brought a willing offering unto the Lord, every man and woman whose heart made them willingly to bring for all manner of work, which the Lord had commanded to be made by the hand of Moses" (Exod 35:29). Moses received all these offerings "which the children of Israel had brought for the work

\footnotetext{
l“Leviticus," SDA Bible Commentary, 1:713.
} 
of the service of the sanctuary, to make it withal. And they brought yet unto him free offering every morning" (Exod 36:3).

This must be a model for us today when we work together to build a place of worship for God. Sacrificial giving is a biblical model for fund-raising. The giving of ourselves to God should be followed by devotion to his service of the best of our possessions. But God values only such gifts as come from a willing heart. We find in 2 Cor 9:7 that "God loves a cheerful giver." This reminds the giver of the great sacrifice of Christ for sins. H.D.M. Spencer explains:

A living Church will show its desire for God's presence, and will evince its gratitude, and its sense of obligation to him, by large and willing gifts in his service. These, indeed, are not conclusive as proofs of genuine spiritual interest; but the absence of them speaks with sufficient plainness of spiritual coldness.'

Sacrificial giving is God's way of raising the hearts of his people to a higher level of commitment in his service.

God is a God of order. He is not glorified when his work is done in a haphazard manner. Divine principles should accompany every aspect of the work of God. The planning, the designing, the fund-raising, the workmanship, everything involved in the building of the Hebrew sanctuary was done according to divine plan. God gave detailed instructions of how his work should be carried out, and these instructions were followed. Nothing was done in a random manner. There was good order and good planning. God's plan for the Church is still the same today. Sacrificial giving was most successful in providing the necessary funds for the tabernacle. God's people need to follow his way to have true success. When the people follow God's plans, they will be blessed accordingly.

'H.D.M. Spence, The Pulpit Commentary (Grand Rapids, MI: Wm. B. Eerdmans Publishing Association, 1961), 1:244. 
The Building of Solomon's Temple

The construction of Solomon's temple serves as a useful model for us today as we work to construct a place of worship. One clear lesson offered by this is that God not only asks for our willingness to do his work, but he requires from us clean hearts. God does not take delight in a sacrifice that is not accompanied by a pure heart, as the psalmist says, "You do not delight in sacrifice, or I would bring it; the sacrifices of God are a broken spirit; a broken and a contrite heart, O God, you will not despise" (Ps 51:16, 17).

David had it in his heart to build a house of worship for God, but this was not God's plan for him. David was a man of war and had shed much blood. We read in $1 \mathrm{Chr}$ 22:8 that David knew that God would not have him build the temple. He could have refused to do anything for the temple because God had rejected his plans, but instead he humbly made all the plans for his son Solomon to do it. This is another important lesson for us today. God's plans are not always in line with our own. In the end, we must always follow the will of God, just as David did.

Not only was David willing to be actively invested in the process, even though his own wishes had been denied, but he made sure to make plans for those who would succeed him. Again, this is an important lesson for us church builders today. David faithfully laid a solid foundation for the construction of the temple; he provided all the necessary resources for his son Solomon to complete the work. Despite his own disappointment, David made extensive preparations for his son Solomon to build a magnificent structure for God (1 Chr 22:2-19).

Part of these preparations entailed gathering together all the foreigners living in Israel and giving them instructions about the building of the temple. 
So David gave orders to assemble the aliens living in Israel, and from among them he appointed stonecutters to prepare dressed stone for building the house of God. He provided a large amount of iron to make nails for the doors of the gateways and for the fittings, and more bronze than could be weighed. (1 Chr. 22: 2-5) ${ }^{1}$

In addition to gathering together and providing the materials to build the temple, David prepared a tent for the Ark of God. He returned the Ark from the house of Abinadad and took it to Kidron, then he brought it to Jerusalem. "After David had constructed a building for himself, in the city of David, he prepared a place for the Ark of God and pitched a tent for it" (1 Chr 15:1-3).

The actions of David provide a worthy example for all those who desire to build a place of worship for God today. This is a model for building the old waste places (Isa 58:12) and for restoring to God that which belongs to him. David restored the Ark of the Covenant, which was a Divine symbol for worship. He inspired the people in their devotion to God. Thus when the temple was completed, the Divine Presence filled the building, signifying approval. "Then the temple of the Lord was filled with a cloud, and the priests could not perform their service because of the cloud, for the Glory of the Lord filled the temple of God" (2 Chr 5:13, 14).

The preparation and the building of Solomon's temple contributed to the restoration of order and spiritual discipline among the people of God at a time of chaos.

As the central worship centre for the nation of Israel, Solomon's temple was an integral part of God's design for maintaining order and/or restoring order in the social and religious life of his people. This was accomplished primarily in one of two ways, 1986), 565.

${ }^{1}$ Charles Caldwell Ryrie, The Ryrie Study Bible (Chicago, IL: Moody Press, 
since the temple was the place for sacrifices (2 Chronicles $2: 6 ; 7: 12$ ) and a house of prayer (Isa 56: 7). ${ }^{1}$

\section{Summary}

In the Old Testament, we find that the ark built by Noah, the sanctuary built by Moses, and the Temple built by Solomon all bore representations of heavenly realities. They were microcosms of Divine order and the center of religious activities. They were commanded by God and were built by the sacrifices of willing hearts under difficult circumstances. All three buildings required painstaking preparations. In all cases, those responsible for the work were faithful to God and obedient to his commands. These are useful models for us today as we work to build a house of God.

\section{New Testament Principles for Church Building}

In the New Testament, we learn much from the teachings of Jesus. From Jesus' statement that "upon this rock I will build my Church" (Matt 16:18), we can deduce that the teachings of Jesus are reliable. They are firm and remain the foundation upon which the Church of God should be built. In Luke 14: 28, again Jesus said, "For which of you, intending to build a tower, sitteth not down first, and counteth the cost, whether he have sufficient to finish it."

The church as the place of worship takes on new characteristics in the New Testament. Here, Jesus established the Church as a community of believers, the calledout ones. According to Collin Brown, the word church, or ekklesia, is only used twice in the Gospels: "What is immediately striking about ekklesia is that, with the exception of

\footnotetext{
'Andrew E. Hill, The NIV Application Commentary (Grand Rapids, MI: Zondervan Publishing House, 2003), 422-423.
} 
Matt. 16: 18 and 18: 17, the word is entirely absent from the gospels." This suggests that the Apostles had a new understanding of church. While not much is said about the physical building in the New Testament, there is much counsel about the church as an event or the church as the building up and equipping the people in Christ. In fact, God's presence is not confined to any one particular place. Jesus never erected a building, but, rather, he established a presence by his many acts of miracles and teachings. There is no particular location designated for worship, because God can dwell with his people at any place and at any time. The principles that we can learn from the New Testament and apply to the construction of a place of worship today include the following: (1) the place of worship should be built with the idea of flexibility in the use of its space; (2) the safety and the security of the Church is centered in Jesus Christ as the foundation pillar ( $\mathrm{He}$ is the chief cornerstone); and (3) plans for building must be made before construction starts.

There are several arguments for flexibility in the use of church space, for using the church building as a multipurpose facility. The first argument is found in the statement of Jesus in Matt 18:20. Here, Jesus sets a pattern for the church in our time. He says that "where two or three are gathered together in [his] name," he will be there "in the midst of them." To many this text suggests that the presence of God is not confined to any particular place. This seems to suggest that the church as a place of worship can be in a gymnasium, an industrial complex, a store front, a school, or a community center.

Wherever people meet to pray, God is there. William Barclay says,

Jesus is just as present in the little congregation as in the great mass meetings. He is just as much present at the prayer meeting or the Bible study circle with their handful of people as in the crowded arena. He is not a slave to numbers. He is there

${ }^{1}$ Colin Brown, "Church," Dictionary of New Testament Theology, 3 vols. (Grand Rapids, MI: Zondervan Publishing House, 1979), 1:297. 
where faithful hearts meet, however few they may be, for he gives all of himself to each individual person. ${ }^{1}$

Whether a building is large or small, the importance is that the people are there together with God. There is some disagreement about this. Some people argue that the building must be large and others suggest that there is not even the need for a physical structure as a holy place for worship. Since God is everywhere, why would we need a dedicated place of worship? In his book, Effective Use of Church Space, Ralph L.

Belknap refers to an address given by Edward A. Sovik at an International Congress on arts and architecture in which Sovik argues that our responsibility does not entail selecting "certain places" of worship and calling them "holy." Rather, suggests Sovik, our responsibility is "to see the whole world as holy and therefore manage it, care for it, and put it in the kind of order that reflects a conviction that the whole earth is the house of God."

Another argument with respect to the necessity of flexible space in a church building relates to what happened when Jesus died on the cross. The death of Jesus brought to an end the sacrificial ministry in the Old Testament, symbolized by the veil of the temple being rent from top to bottom as described in Matt 27:51. The argument can be made that since the form of worship has changed, so must the place of worship. There is now a need to make the location conform to the needs of people without compromising the message.

\footnotetext{
${ }^{1}$ William Barclay, The Gospel of Matthew, vol. 2 (Philadelphia, PA: Westminister Press, 1976), 191.

${ }^{2}$ Ralph L. Belknap, Effective Use of Church Space (Valley Forge, PA: Judson Press, 1978), 54.
} 
A third argument in favor of church space being flexible space stems from the reality that church buildings that are designed for a single use can be very expensive to maintain, especially those that are used only once a week. Belknap points out that "financial problems are increasing rapidly for many churches. The budget crunch is being felt everywhere. One aspect of the crunch is that, because of inflation, higher salaries are necessary to find and retain talented ministers." But salaries are not the only problems related to cost. Insurance, maintenance, heating, lights, and air conditioning are all associated with the proper functioning of a new building. In the midst of a time of change, and in light of financial restraints, it may be necessary to move things around in the church building to make space for multi-purpose activities during the week, including those related to health care, child care, education, as well as other social events.

The New Testament provides insight into the foundations of the church today. In Matt 16:18, we find that Jesus said to Peter, "And I say also unto thee, that thou art Peter, and upon this rock I will build my Church; and the gates of hell shall not prevail against it." What does Jesus mean by "upon this rock"? This statement by Jesus has been the source of many debates. Who or what is the rock on which the church is built? According to the Seventh-day Adventist Bible Commentary, there are three main views: (1) Peter is "this rock"; (2) Peter's faith in Jesus as the Christ is "this rock"; and (3) Christ himself is "this rock." For the purpose of this dissertation, all three interpretations shall be considered as correctly identifying "the rock" upon which Jesus built his church. The

\footnotetext{
${ }^{1}$ Ibid., 53.

2“"Matthew," SDA Bible Commentary, 5: 430.
} 
teachings of Jesus form the basis for all good conduct and behavior in society and the Church. According to one New Testament Bible commentary,

Matthew's record of Jesus' wordplay on Peter's name is significant. Petra is feminine and while clearly related, they represent a distinction. The masculine singular form refers to Peter as a singular rock. The feminine form may be understood to represent bedrock or a rock quarry (the disciples). It was upon this quarry of disciples (living stones 1 Pet 2:5) and their understanding of Peter's confession that Jesus would build his Church.'

Peter was the first to declare his confession of Jesus as the foundation of the new Christian community, that Jesus would use these new believers and their testimony of him to establish the church. William Barclay explains: "Peter is the foundation in the sense that he was the first of that great fellowship who joyfully declared their own discovery that Jesus Christ is Lord; but that, in the ultimate sense, it is God himself who is the rock on which the Church in built."

Jesus built the Church upon godly works, the spiritual witness (Eph 2:19-22), and the fidelity of the disciples. It is Christ's power that holds the Church together (1 Pet 2:48). Without Jesus, everything falls apart. Jesus is the only sure foundation and there can be no other true foundation (1 Cor 3:11). A lesson can be drawn from this regarding the safety and security of the church. According to some New Testament scholars, Jesus used "Peter's great confession as an occasion to reveal a mystery hidden even from the Old Testament Prophets." This mystery was that while "the Church (assembly) was in God's plan in His eternal purpose from the beginning (Eph 3:9-11)[, . . it could not be

${ }^{1}$ Max Anders, Holman New Testament Commentary (Nashville, TN: Broadman and Holman Publishers, 2000), 251.

${ }^{2}$ Barclay, 2:142. 
revealed until Jesus was recognized as its divine head (Eph 1:22; Col 1:15-18)."1 Peter represented the first in a new community of believers that Jesus would use to establish the visible assembly on earth for a particular purpose.

Not only must the church be safe and secure on a firm foundation symbolically, but also physically. In Matt 21:42, we read, "Jesus said unto them, did ye never read in the Scriptures, the stone which the builders rejected, the same is become the head of the corner: this is the Lord's doing, and it is marvelous in our eyes?" A building is strong when the foundation is made of rocks and stones. These provide the greatest safety and security against disasters. Jesus told his disciples: "Therefore whosoever heareth these sayings of mine, and doeth them, I will liken him unto a wise man, which built his house upon a rock" (Matt 7:24).

Safety is of key importance in the construction of a church building. The entire structure and its surroundings should have a system in place to deal with hazards and poor workmanship and measures that can effectively reduce injuries and liabilities.

Jeffrey W. Hanna makes this point:

The physical conditions of the church buildings can cause us concern. If needed repairs are deferred, members and visitors can be exposed to potential harm and the congregation to significant liability. In many states the care of invitee carries a much higher level of liability than the care of regular attendees. The outsiders are in unfamiliar surroundings and less aware of hazards in the church building. ${ }^{2}$

Safety for the handicapped must be a concern in church construction.

Consideration must be given for the safety of the elderly, the physically challenged,

${ }^{1}$ Ralph W. Harris, Stanley M. Horton, and Gayle Gerrity Seaver, The New Testament Study Bible (Springfield, MO: Complete Bible Library, 1989), 347.

${ }^{2}$ Jeffrey W. Hanna, Safe and Secure: The Alban Guide to Protecting Your Congregation (Bethesda, MD: Alban Institute, 1999), 33. 
children, women, as well as for valuable equipment and other church property. The church needs to carry adequate liability insurance to protect from damages caused by inclement weather, equipment malfunction, spills, and poor workmanship.

Just as the physical surrounding of the church building can cause serious liability to those using the premises, so the spiritual conditions of the church can become a danger to visitors and new believers and even the regular members themselves. Jesus Christ represents the spiritual as well as the physical structure of the Church. The Apostle Paul said, "For other foundation can no man lay than that is laid, which is Jesus Christ" ( 1 Cor 3:11). Therefore, Jesus represents the spiritual and physical foundation of the church. Every thing must be done to give the church a solid, secure structure, and everything must be done with Christ as the source.

Another lesson given to use in the New Testament is the importance of honesty. This counsel is given in 1 Thessa 4:12: "That ye may walk honestly to them that are without, and that ye may have lack of nothing." Those involved with the construction of the church building, whether they are Christians or not, should be honest. They should learn that while working on the project, there should be no stealing of tools or the materials for the church building. Furthermore, this honest work must be rewarded with honest pay, as we find in Luke 6:38: "good measure, pressed down, and shaken together, and running over, shall men give into your bosom. For with the same measure that ye mete withal it shall be measured to you again." Every man's work should be tested or inspected to see if the work is done well to meet safety standards. All work must be honestly performed and rewards should be just. 
Counsel is also given in the Scriptures about the kind of language used during the building process. Matt 5:34 reads: "But I say unto you, Swear not at all; neither by heaven, for it is God's throne: Nor by the earth; for it is his footstool: neither by Jerusalem; for it is the city of the great King. Neither shalt thou swear by the head, because thou cannot not make one hair white or black." Counsel is also given regarding how to handle disputes. In Matt 5:25, we are told to “Agree with thine adversary quickly, whiles thou art in the way." We must settle disputes quickly before the matter is forgotten.

All the while, security must remain an important concern in the construction of a church building. Both during and after construction, the church should be protected from intruders. Jeffrey W. Hanna points out that "many churches don't know who has access to their buildings." A serious concern for church safety is protecting the church from those who have access to the building. We must keep in mind that keys once given may be duplicated and handed to others who may not behave responsibly. Church buildings need to be protected from those who previously had keys, and from negligence and other misconduct of church members.

An important lesson we find in the New Testament is the need to make plans before construction begins. As Jesus said, "For which of you, intending to build a tower, would not sit down first, and counteth the cost, whether he have sufficient to finish it?" (Luke 14:28) A wise builder should know the financial resources available for the project before starting construction. Lack of funds has caused delays, led to frustration, and even ended up in conflicts over church construction projects. One way to plan is to have all

\footnotetext{
${ }^{1}$ Hanna, Safe and Secure, 17.
} 
agreements in writing before the construction begins. Monetary pledges and work

agreements for all services for the operation of the building should be secured before the work begins. In the early Christian church, the believers were committed to the work of the gospel promulgation. The Holy Spirit moved upon each new believer and they made sacrificial commitments to the work of God:

And the multitude of them that believed were of one heart and one soul: neither said any of them that ought of the things which he possessed was his own; but they had all things common.

And with great power gave the Apostles witness of the resurrection of the Lord Jesus: and great grace was upon them all.

Neither was there any among them that lack: for as many as were possessors of lands or houses sold them, and brought the proceeds of the things that were sold,

And laid them at the apostle's feet: and distribution was made unto every man according as he had need. (Acts 4:32-35)

To make a pledge is to agree to give a certain amount of money, either given in one lump sum or spread out over a period of time. It is a promise of commitment to the funding of the project. Belknap points out that pledging has the "very practical result" of indicating whether the "level of church income [is] sufficient to meet mortgage payments." Pledges give the assurance that plans for the work can proceed with the hope of receiving support at specific times. Proper commitment to the project will give the necessary assurance that a work begun will be brought to completion without embarrassing delays.

\section{Principles from Ellen G. White on Building a Place of Worship}

This final section of chapter 2 covers some practical advice offered by Ellen G. White with regard to building a place of worship for God. White's comments cover

\footnotetext{
${ }^{1}$ Belknap, 143.
} 
various planning issues as well as fiscal responsibility in building God's house for worship. The lessons she offers can be applied today. Recognizing that there will always be difficulties in building places of worship in large cities, she advises that we need to work as expeditiously as possible to avoid unnecessary debt, haphazard plans, disunity, and a lack of faith in the promises of God.

White points out that the church building stands as a memorial of truth for God.

Church buildings should be erected everywhere as memorials of truth.

When an interest is aroused in any town or city, that interest should be followed up. The place should be thoroughly worked until a humble house of worship stands as a sign, a memorial of God's Sabbath, a light amid the moral darkness. These memorials are to stand in many places as witnesses to the truth ${ }^{1}$

Memorials for God's Sabbath are to be established in accordance with the great commission from God. Speaking to the Conference officials in Australia in 1900, White appealed, "Lift up the standard; establish memorials in every place."2 Obedience to God's word will result in the establishment of these places of memorial. When God's word is obeyed, there are "memorials for Him in every city and village." 3 Speaking of the work that is to be done in our large cities, White counsels that we must take advantage of every opportunity to build, knowing that God will send us help from people who are not of our faith.

We must be eager to see the work advance in every place especially in the large cities. We are far behind in following the light given to us to enter the cities and erect memorials for God. ... We are to continue working until a church is organized and a humble house of worship built. I am greatly encouraged to believe that many persons

${ }^{1}$ Ellen G. White, Testimonies for the Church, 9 vols. (Mountain View, CA: Pacific Press Pub. Assn., 1948), 6:100.

${ }^{2}$ Ellen G. White, "An Appeal," Australian Union Record, January 1, 1900, 31.

${ }^{3}$ White, Testimonies, 9:28, 29. 
not of our faith will help considerably by their means. The light given me is that in many places, especially in the great cities . . . help will be given by such persons.'

One piece of important advice offered by White is to keep in mind that debt is a hindrance to building places of worship. Very often, the work of God is hindered because of insufficient funds and excessive debt. Regarding debt, White writes the following:

It is displeasing to God for our churches to be burdened with debt. "The silver is mine, and the gold is mine, saith the Lord of hosts" (Hag 2:8). When that gold and silver is used for selfish purposes, to gratify ambition or pride or desire for any selfish indulgence, God is dishonoured. When the people chosen by God embellish their own houses and invest His money in selfish gratification, leaving His cause to languish, they cannot be blessed.

When you place the Lord first, and determine that His house shall no longer be dishonoured by debt, God will bless you. Every week endeavour to lay aside something for this object, something in addition to your tithe money. ... In making this offering, every member of the family will receive a blessing. ${ }^{2}$

White balances this statement by pointing out that even though debt is a hindrance, there are times when it is necessary to borrow money for the advancement of the work. Sometimes it is necessary to borrow money and pay interest rather than to suffer other inconvenience.

It is right to borrow money to carry forward a work that we know God desires to have accomplished. We should not wait in inconvenience, and make the work much harder, because we do not wish to borrow money. Mistakes have been made in incurring debt to do that which could well have waited till a future time. But there is danger of going to the other extreme. We are not to place ourselves in a position that will endanger health and make our work wearing. We are to act sensibly. We must do the work that needs to be done, even if we have to borrow money and pay interest. ${ }^{3}$

${ }^{1}$ Ellen G. White, Reflecting Christ (Washington, DC: Review and Herald Pub. Assn., 1985), 241.

${ }^{2}$ Ibid., 103.

${ }^{3}$ Ellen G. White, Counsels on Stewardship (Washington, DC: Review and Herald Pub. Assn., 1940), 278. 
Elsewhere, she writes that we need the wisdom of God on the matter of acquiring

debt. We must move forward by faith and work purposefully.

In laying plans for the building, we need the wisdom of God. We should not needlessly incur debt, but I would say that in every case all the money required to complete a building need not be in hand before the work is to begin. We must often move forward by faith, working as expeditiously as possible. It is through a lack of faith that we fail of receiving the fulfilment of God's promises. We must work and pray and believe. We are to move forward steadily and earnestly, trusting in the Lord, and saying, "we will not fail nor become discouraged."

White points out that it is not necessary to build expensive and extravagant places for worship, such as Solomon's temple. The building should be plain and neat, reflecting the humility and perfection that is of Christ. White explains that "we have no command from God to erect a building which will compare for richness and splendour with the temple [Solomon's]. But we are to build a humble house of worship, plain and simple, neat and perfect in its design."2 In response to a request to clarify her remarks on the simplicity of the church building, she explains that she "wish[es] our buildings to represent the perfection God requires from His people."

White counsels that in building churches we should not seek to gain attention by an outward display of means. Rather, we should reflect the humility of Christ. God does not bless us because of the structure. "Outward show and large outlay of means are not necessary in order to gain the blessing of God. Human taste, human devising, human

${ }^{1}$ Ibid., 280.

${ }^{2}$ Ellen G. White, Evangelism (Washington, DC: Review and Herald Pub. Assn., 1946), 377.

${ }^{3}$ Ibid., 378. 
inclination to ornament, are not to be encouraged. An unnecessary expedition of money means that there will be less to invest in the work of God."

Money should be used to build more places of worship, not expensive and elaborate buildings. The building should be built to please God and not for human display. It is not a means to gain attention but rather a way to serve God in proclaiming the gospel. Our buildings must reflect an understanding of the times.

I am instructed to say to our people: consider the warnings God has sent regarding the closing up of this earth's history. It is not now a time for us to make a great display in large buildings. ... We are delivering sermons in every building we erect, and these things are taken as testimonies borne of our faith, while these very buildings testify that we are not expecting to move soon from this world to the heavenly. ${ }^{2}$

White's counsel is that we should exercise great care in spending God's money.

We should consider that there are needs in other areas of the Lord's vineyard. "Those who have the money in God's treasury are to economize in the use of means, and they are to consider carefully the needs of the work in the home field and in the regions beyond. If they did this they would not erect mammoth institutions contrary to the instruction of God." ${ }^{\prime 3}$

At all times, we should exercise great care in starting a building project. The building should reflect the character of the work. White offers this advice regarding the

'Ellen G. White, “Work in Christ's Line," Review and Herald, 24 June 1902, 8.

${ }^{2}$ Ellen G. White, to Dear Brethren and Sisters in Washington, June 6, 1909, Letter B 94a, 1909; quoted in Eduardo Aurita, "Towards a Theology of the Seventh-day Adventist Meeting Place, with a Study of Practical Implications and Applications Thereof' (Project Report, Andrews University, Berrien Springs, MI, 1984), 86.

${ }^{3}$ Ellen G. White, MS 53, 1903, Ellen G. White Research Center, Andrews University, Berrien Springs, MI. 
construction of a meeting house in Richmond: "Exercise care and wisdom in the erection of this building. ... A humble house of worship will give character to the work.

Buildings give character to the work only when those who build do so in the counsel and spirit of the Lord, when the work is carried forward with an eye single to the glory of God, and according to his instructions."

One of the most important instructions given to us by White is that money for the financing of church-building projects should not come from tithe funds. "Those who have charge of our church buildings are to be supplied with means necessary to keep these buildings in good repairs, but this money is not to come from the tithe."2

As we exercise care in spending God's money, we must keep in mind the importance of building with economy. White counsels that there should be no extravagance in building a place of worship. Even when there are enough funds to undertake an elaborate, expensive building project, we must not. We must always act on eternal principles rather than making a display of our means. "Our economy should testify of our principles. We should employ methods of work that are not transient. Everything should be done solidly for time and eternity." In dealing with the use of funds, it cannot be overemphasized how clear White is about the need to take great care in how the funds are used. We should always consider new fields that are opening up that might need more funds. It is not "in accordance with the mind of the spirit of God to lay

${ }^{1}$ Ellen G. White to Elder J. D. Rice, 11 December 1908, letter R 342, Ellen White Research Center, Andrews University, Berrien Springs, MI.

${ }^{2}$ Ellen G. White, “The Use of the Tithe," Echoes from the Field, June 21, 1905, par. 2.

\footnotetext{
${ }^{3}$ White, Testimonies for the Church, 6:101-102.
} 
plans for an expensive structure, even if we had plenty of means to invest, for the reason that new fields are constantly opening, and we should take every precaution that not a dollar shall be laid out for the sake of display, or the indulgence or pride. Every dollar of means will be needed to start the work in new mission fields."

White's point is that costly displays go against the plan of God when there is need for building houses of worship in other places. Writing to a group of believers in California she counsels against putting a large amount of money into any one building: "At this time the building of costly meeting houses in any place is not in accordance with our faith. There are many places where meeting houses will soon have to be built; therefore we should not put large sums of money in any one place."2

Nonetheless, even though she emphasizes economy in building, she also underscores the importance of the high quality and perfection that is required of God's people, emphasizing that the house of God should be built with good quality materials. "Would we dare to dedicate to God a house made of cheap material, and put together so faultily as to be almost lifted from its foundation when struck by a strong wind? We would be ashamed to put worthless material into a building for the Lord. And I would not advise anyone to put worthless material into a house. It does not pay."

Whites counsels that every part of the building should be put together well. The building should not be made of cheap material, but rather with the beauty and perfection

${ }^{1}$ Ellen G. White, MS 49, Ellen G. White Research Center, Andrews University, Berrien Springs, MI.

${ }^{2}$ Ellen G. White to Members of Oakland Church, 18 January, 1907, Letter 10, Ellen G. White Research Center, Andrews University, Berrien Springs, MI.

${ }^{3}$ White, Evangelism, 378. 
of Christ. "Christ is our example in all things. He worked at the carpenter's trade with His father Joseph, and every article He made was well made, the different parts fitting exactly, the whole able to bear test." We should follow Christ's example when building a house of worship.

Lessons that White offers include emphasizing the importance of making pledges for the building fund. Speaking at an 1888 meeting in Fresno, California, White talks about an incident in which people came forward with pledges:

After the good meeting on Sabbath, some of the prominent brethren met to consider the matter of erecting a house of worship, and the other building spoken of. All were anxious that the plans might be carried out. Sunday forenoon the Church assembled to act upon the suggestions given, and the result was beyond our most sanguine expectations. Every member of the Church gave a tangible proof of his interest in the enterprise. Thirty thousand dollars were pledged for the work, before this meeting was dismissed. ${ }^{2}$

Pledges are tangible proofs of the interest of individuals. Those who make pledges must fulfill their responsibilities to the Lord. "Let not those who have made pledges to carry on the work of God repent of their vows, and withhold that which they have given,"3 counsels White. A pledge made in the presence of other believers carries with it the same seriousness as a contract made to the bank for a mortgage. A pledge is a commitment to God, and the church cannot release a person from it. It is a visible witness of one's inward commitment to God. And his word and a person should feel a need to

${ }^{1}$ Ibid., 378.

${ }^{2}$ Ellen G. White, "The Work at Fresno, California," Review and Sabbath Herald, June $19,1888,3$.

${ }^{3}$ Ellen G. White, "To Those Making Large Gifts to the Cause of Present Truth," The Northern Union Recorder, April 16, 1907, 3. 
honor that pledge. "No legal bond is more binding upon the Christian for the payment of money, than a pledge made to God."'

A pledge is a lesson in liberality, and churches are responsible to remind those who make pledges for the work of God to carry out their commitment. Writing about pledges, White offers the following example: "The Apostle refers to the fact that a year before, a gift had been pledged; but there had been no realization of this pledge. The Apostle now had an efficient helper whom he could send out to the Churches reminding them of their pledges, lest they should fail to carry out their good resolutions. It was essential for the repute of the Church that they should now make good the promise they had made a year before." 2

A pledge is as binding as a legal document. It is a sacred responsibility to honor a commitment made to the church. A pledge to God is not less biding than any other legal commitments that are made to man.

The people need to be impressed with the sacredness of their vows and pledges to the cause of God. Such pledges are not generally held to be as obligatory as a promissory note from man to man. But is a promise less sacred and binding because it is made to God? Because it lacks some technical terms, and cannot be enforced by law, will the Christian disregard the obligation to which he has given his word? No legal note or bond is more obligatory than a pledge made to the cause of God. ${ }^{3}$

Christians should be encouraged not to disregard their spiritual obligation to God. While White makes clear that tithes should not be used for building projects (see above), she nonetheless refers to something called a "second tithe" that can be used to increase a

${ }^{1}$ White, Counsels on Stewardship, 315.

${ }^{2}$ Ellen G. White, “A Lesson in Liberality," Pacific Union Recorder, November $14,1907,2$.

3“Acts," SDA Bible Commentary, 6:1056. 
building fund. She draws on an example from the Old Testament in which funds to care for the poor were raised through a second tithe. In speaking of the need for the work in Australia in 1903, she refers to the cheerful response of the people and the "second title [that] was set apart to increase the building fund."

She recognized that the second tithe in Scripture was used to provide needed funds to help the poor and those in need. White more fully develops the idea of the second tithe in the following:

To promote the assembling of the people for religious service, as well as to provide for the poor, a second tithe of all the increase was required. Concerning the first tithe, the Lord had declared, "I have given the children of Levi all the tenth in Israel." Numbers 18:21. But in regard to the second He commanded, Thou should eat before the Lord thy God, in the place which He shall choose to place His name there, the tithe of thy corn, of thy wine, and the firstlings of thy herds and of thy flocks; that thou mayst learn to fear the Lord thy God always." Deuteronomy 14: 23, 16:11-14. This tithe, or its equivalent in money, they were for two years to bring to the place where the sanctuary was established. ${ }^{2}$

Aside from the sacrificial gifts of church members, White is clearly open to the idea of receiving funds from our many friends outside the congregation, people who are just as willing to give to the building of God's house as are the members. She refers to the experience of Nehemiah to support this idea. "Nehemiah did not depend upon uncertainty. The means that he lacked he solicited from those who were able to bestow. And the Lord is still willing to move upon the hearts of those in possession of His goods,

${ }^{1}$ White, The Needs of the Cause in Australia, 21.

${ }^{2}$ Ellen G. White, Patriarchs and Prophets (Mountain View, CA: Pacific Press Pub. Assn., 1943), 530. 
in behalf of the cause of truth. .. The donors may have no faith in Christ, no acquaintance with His word; but their gifts are not on this account to be refused."'

God has money in the hands of the gentiles and the Church must devise ways and means to ask for that money. The Lord will work on the hearts of worldly persons to give. The Lord will work upon "even idolaters," writes White. The key is to "approach them wisely, and give them an opportunity of doing those things which is their privilege to do. What they would give we should be privileged to receive."' White was aware that some believers would object to the church's taking money from the gentiles to build a place of worship for God. Regarding this object, White writes:

Times are growing hard, and money is difficult to obtain; but God will open the way for us from sources outside our own people. I cannot see how anyone take exceptions to the receiving of gifts from those not of our faith. They can only do so by taking extreme views, and by creating issues which they are not authorized to do. ... The money is the Lord's, and if the wealthy are approached in the right way, the Lord will touch their hearts, and impress them to give of their means. God's money is in the hands of these men, and some of them will heed the request for help. ${ }^{3}$

The primary responsibility for raising the funds rests with members of the church, of course. White points out that when every member in the church sets aside a sacrificial offering for the work of the Lord each month, there will be adequate funds for building a house for God. This plan of systematic benevolence, if "adopted by every individual and fully carried out," will lead to "a constant supply in the treasury. The income would flow

${ }^{1}$ Ellen G. White, Prophets and Kings (Mountain View, CA: Pacific Press Pub. Assn., 1943), 634.

${ }^{2}$ White, Counsels on Stewardship, 185.

${ }^{3}$ Ibid., 187-188. 
in like a steady stream constantly supplied by overflowing spring of benevolence."' It is God's plan that everyone should act a part in building up the work, and he will bless his people: "God has devised a plan by which all may give as He has prospered them, and which will make giving a habit without waiting for special calls."2 White points out that just like there is "order in heaven, ... God is well pleased with the efforts of His people in trying to move with system and order in His work on earth." ${ }^{3}$ God's plan is that there should be a system by which the financial aspect of the work will go forward successfully. "God is leading His people in the plan of systematic benevolence, and this is one of the very points to which God is bringing up His people which will cut the closest with some."

Systematic benevolence is a plan to which God invites every member of the church to act a part. It is a safeguard against the temptation of spending carelessly, and it proves a blessing to the rich by guarding them from indulging in extravagances. Nothing should hinder us from performing our first duty to God. White points out that some may resist being "united in the plan of systematic benevolence, excusing themselves because they were not free from debt." These people "plead that they must first "owe no man any thing.' But the fact that they are in debt does not exclude them."' Still others, continues

${ }^{1}$ White, Testimonies, 3:389-390.

${ }^{2}$ Ellen G. White, "Systematic Benevolence," Second Advent Review and Sabbath Herald, January 1, 1875, par. 9.

${ }^{3}$ White, Testimonies, 1:191.

${ }^{4}$ Ibid.

${ }^{5}$ Ibid., 1:220, 221. 
White, "have felt under sacred obligations to their children. They must give each a portion, but feel themselves unable to raise means to aid the cause of God. They make the excuse that they have a duty to their children." While White agrees that it "may be right" for them to feel this duty to their children, they must also remember that "their first duty is to God."

Systematic benevolence is a constant living test. It helps us to understand our true natures, to understand whether our first duty is to God or the things of the world. As a result of voluntarily taking part in this plan, the heart will be opened to receive blessings from God.

\section{Summary and Conclusions}

The Bible and the writings of Ellen G. White contain many principles that can be used as the foundation for finding and constructing a suitable building for a place of worship. In the Old Testament Scriptures, God commanded a building as a place for worship so that he could dwell among his people. Noah built the Ark at the command of God. It was designed as a place of refuge for the salvation of the people of Noah's generation. Noah preached salvation to the people while he was building the Ark. Although many of those who helped in the construction were skeptics, their help was not rejected.

The Hebrew Sanctuary was another project that was designed by God. It was a building with several compartments that was used continually for the worship and service of God. Moses oversaw the building project, working with skilled laborers in its construction. The funding of this project came through volunteers who gave willingly.

'Ibid. 
Both Noah and Moses obeyed God with all their hearts and were moved by faith to do God's will. They thus set a perfect example for followers of God in all generations. In the New Testament Scriptures, there is no clear emphasis on any one particular place for worship. Jesus Christ sets the pattern for the building of a place of worship in our time. For Christ, every place where people meet is a great place for worship. Jesus told the Samaritan woman at the well that "the hour cometh, when you shall neither in this mountain, nor yet at Jerusalem worship the Father" (John 4:21). Those who worship God must worship him in Spirit and in truth (John 4:24). Jesus likens himself to the temple (John 2:19,21). He is the chief cornerstone of the church, and his teachings form the foundation for every church building project. Other New Testament writers emphasize the building of people for spiritual service. Paul calls believers temples of God ( 1 Cor $3: 16,17 ; 6: 19$ ), and points out that every believer should be gifted so that he or she can share the graces of God to the world.

White counsels that the building of places of worship should be established everywhere as a memorial for God and the Sabbath. The physical building should not be over-emphasized, however, so that we forget to equip people for service. The purpose of building a place of worship is to teach and preach the word of God. 


\section{CHAPTER 3}

\section{THE HISTORY OF THE DOWNSVIEW SEVENTH-DAY}

\section{ADVENTIST CHURCH}

This chapter focuses on placing the Downsview Seventh-day Adventist Church in its historical context and situating it in its geographic and economic setting and its cultural milieu. The chapter is divided into three sections. The first section describes the geographic, cultural, and economic makeup of the area in which the church is located. The second section outlines the history of the church from its beginning in 1979 until August 1994. Of particular focus in this section is the way the church began and the challenges that the congregation had to go through in order to carry out the church's mission. The third, and by far longest, section provides an overview of the history of the church from September 1994 to the end of 2004. The focus in this section is the process that made it possible for the purchase of the first site for a place of worship, including the trends, the vision, and how this vision was communicated to the congregation.

\section{Geographic, Economic, and Cultural Profile of the Church's Community}

Downsview is a suburb of the City of Toronto, located in the northwest area of the city. "It is bounded by Highway 400 and Jane Street to the west, Dufferin Street to the East, Steeles Avenue West to the North, Grandravine Avenue and Sheppard Avenue 
West to the South." According to the latest information from Statistics Canada, this area is the home to more than 51,860 people. "Approximately $60 \%$ of all the occupied dwellings are in high-rise apartments, $13 \%$ are in row houses; and 13\% are in single detached houses; $68 \%$ of the occupied private dwellings were rented, while $32 \%$ were owned."2

Downsview is a very diverse community, with a number of cultural groups living in the area. According to Statistics Canada, the top ten "Ethnic Origin Groups" are as follows: Italian, East Indian, Jamaican, Chinese, Vietnamese, Canadian, Spanish, Guyanese, Tamil, and Sri Lankan. ${ }^{3}$ As further shown in table 2, Jamaicans make up the third largest visible minority group that lives in the area. Other visible minority groups living in the community of Downsview are shown in table 3.

The Downsview area is made up of working-class neighborhoods. The main businesses that provide employment for individuals and families are found in "manufacturing and processing, sales and service, business finance and administration, trades, transportation and equipment operators," and the average household income is $\$ 43,615$ yearly. ${ }^{4}$

'Statistics Canada, 2001 Census, http://www.city.toronto.on.ca/wards2000/wards.htm

${ }^{2}$ Ibid.

${ }^{3}$ Statistics Canada, 2001 Census, Urban development Services, City Planning, Policy and Research, September 2003, http://www.toronto.ca/wards2000/pdf/wardprofiles_08.pdf.

${ }^{4}$ Statistics Canada, 2001 City of Toronto Employment Survey. 
TABLE 2

ETHNIC GROUPS

\begin{tabular}{lc}
\hline Ethnic Groups & Percentage of Population \\
\hline Italian & 9.6 \\
East Indian & 8.5 \\
Jamaican & 8.1 \\
Chinese & 7.8 \\
Vietnamese & 4.5 \\
Canadian & 3.6 \\
Spanish & 2.9 \\
Guyanese & 2.1 \\
Tamil & 1.9 \\
Sri Lankan & 1.7 \\
Others & 9.2 \\
\hline
\end{tabular}

TABLE 3

VISIBLE MINORITY GROUPS

\begin{tabular}{lc}
\hline Visible Minority Groups & Percentage of Population \\
\hline Black & 21.1 \\
South Asian & 15.5 \\
Chinese & 8.4 \\
Southeast Asian & 7.1 \\
Latin American & 6.8 \\
Arab & 1.8 \\
Filipino & 1.6 \\
West Asian & 1.5 \\
Korean & 0.7 \\
Japanese & 0.1 \\
\hline
\end{tabular}


The percentages of people in the labor force (above age 15) working in different types of occupations are shown in table 4 . As the data show, those working in manufacturing and utilities constitute the highest percentage in the workforce, followed by those working in sales and services.

TABLE 4

LABOR AND EMPLOYMENT

\begin{tabular}{lr}
\hline Occupation & $\%$ \\
\hline Management & 4.6 \\
Business, Finance and Administration & 17.4 \\
Natural and Applied Science & 5.7 \\
Health Occupations & 3.2 \\
Social Sciences & 5.6 \\
Art, Culture, and Sports & 1.7 \\
Sales and Services & 21.8 \\
Trades, Transportation and Equipment Operators & 15.9 \\
Manufacturing and Utilities & 23.6 \\
\hline
\end{tabular}

The Early Beginnings and Trends of the Church (1979 to 1994)

The idea of a church in Downsview community came one Sabbath morning, in 1978 , to one Brother Oyeman Mitchell while he was on his way to the Willowdale Seventh-day Adventist Church in Toronto. As was his pattern, that morning he traveled through an area of the city known as the Downsview and thought to himself that it would be a good idea to have a church in that community. He had noticed that there were several other members traveling in the same direction to the same church. He called a small group of members who lived in his same community and asked if they were willing to join him to start a Branch Sabbath School in the Downsview neighborhood. They all 
agreed. They then took the idea to the pastor of the Willowdale Church, who gave them his blessings. After the matter was processed through the Church Board and the Church in Business meeting, a small group was ready to begin meeting in January 1979.' Their vision was to visit every home in the community to tell of the love of Jesus. It was the knowledge of the Great Commission found in Matt 28:19, 20 that led to a desire to see all the people of Downsview come to the knowledge of Jesus Christ. As Harris W. Lee puts it, it is the Scripture that guides the mission of the Church.

To clarify the vision for the Church we begin with what the Scripture sets forth as God's vision for the world. We appropriately ask, What is God's will for the world? What is God doing with His global family, and where is he leading it? What does it mean that God's wills for all to be saved and come to the knowledge of the truth? It is important for the leadership of the Church and of individual congregations to clarify its understanding of the Scripture's vision. ${ }^{2}$

The Downsview Seventh-day Adventist Church thus began as a Branch Sabbath School with a spirited group of thirty-five members. The first meeting took place on January 27, 1979, in the Yorkwoods Community Centre under the leadership of Pastor Milliken, who was the pastor of the Willowdale Seventh-day Adventist Church. ${ }^{3}$ It was the aim of this new group to reach out to the people of the Downsview area, and to share the Everlasting Gospel of Jesus Christ to them. The group fully believed White's counsel that "Sabbath School should be one of the greatest instrumentalities, and the most

'Pastor Oyeman Mitchell of the Hope Seventh-day Adventist Church in Toronto, interview by author, 20 August 2004, Toronto, Canada.

${ }^{2}$ Harris W. Lee, Effective Church Leadership: A Practical Source Book (Minneapolis, MN: Augsburg Fortress, 1989), 28.

3“Downsview Seventh-day Adventist Church Clerk's Report: 1979” (Downsview Seventh-day Adventist Church, Toronto, Canada). 
effectual, in bringing souls to Christ."' They believed they were following White's call for organized work in the cities to reach the people. "Let companies be organized to enter the cities. Seek proper locations for holding meetings. Circulate our literature. Make earnest efforts to reach the people."

This commitment and dedication of the new group led to the official inauguration from a Branch Sabbath School to a church roughly three months later, on March 31, 1979. The thirty-five-member group had rapidly grown to one with sixty-six believers. The aim of this new group of believers continued to be to reach the people of the community with the gospel of Jesus Christ. Initially, there was no plan to build a place for worship. The leadership of the local Seventh-day Adventist Conference was so impressed with the growth of this new group, that a new pastor was assigned to lead in May of the same year.

Although there were many blessings that God gave to the church during its first fifteen years, there were also many challenges it had to face. Pastor Oyeman Mitchell, one of the founding members of this congregation, describes the initial situation:

The Gymnasium that was used for worship, was also used by other community groups. There was no fixed seating. The chairs had to be set up on Sabbath mornings. There was no storage space. Access to the building was from 9:30 A.M. to 12:30 P.M. There was no guarantee use of space. Community activities took precedent over religious activities. The Church was forced to find alternate accommodation when a community event was planned. ${ }^{3}$

${ }^{1}$ Ellen G. White, Counsels on Sabbath School Work (Washington, DC: Review and Herald Publishing Association, 1938), 10.

${ }^{2}$ White, Evangelism, 96.

${ }^{3}$ Oyeman Mitchell, interview, 2004. 
The rapid growth of the group was obviously a blessing, but it too led to a challenge. The new church body was forced to move to a new location. The hope was to find a more convenient place for worship without all the troubles outlined by Mitchell. Although, the members had bright hopes for something better, it was not to be. They could find only a high-school gymnasium. The church continued its mission at its new location in the gymnasium of Westview High School. After conducting an evangelistic outreach program, by the end of February 1980, the church's membership had grown to 114. Very soon, the group discovered that it was facing similar problems at this location as it had in the previous location. The same inconveniences experienced at the community center were also experienced at this new site. The search began for another location. After seven months, the group was on the move again.

The church moved from one high-school gymnasium to another, as there were few alternatives in the area. They now began to meet at C.W. Jeffer's High School but soon found that the problems were the same as they had been before. Nonetheless, the lack of a convenient place of worship did not stop the congregation from visiting in homes and conducting Bible studies with prospective members. As the church's membership continued to grow, the congregation had very little choice but again to seek out better facilities for worship. While school gymnasiums were available on Saturdays, the congregation had to compete with other activities going on in the schools at the same time. Finally, a church was found that would lease space for worship. The congregation quickly took the offer and relocated after having met for only ten months at the C.W. Jeffer's High School location. 
The Cross Road Cathedral was a large and beautiful church with plenty of rooms for Sabbath school classes as well as offices. Thinking that this was the ideal place for worship, the believers were motivated for mission. Now meeting in this beautiful facility for worship, many believers began to dream of a church building of their own. Here, at this location, ideas and thoughts grew and plans were initiated to acquire a place of worship of their own. Here, the congregation formed the first building committee and set up the first building fund.

Inspired by their bold vision, the congregation took another step forward. In an attempt to make it easier for people to attend church, plans were made to purchase a bus. In February 1982, a bus was purchased to transport members to and from church. As the church membership continued to grow, a Pathfinder Club was started for the young people. Several evangelistic meetings were held and many new souls were added to the church. By the end of 1984 , the membership had grown to $181 .^{1}$ The church was on the move, and the focus was on mission and growth, but then trouble came. Without warning, the church was given a notice to vacate. Adding to this, the bus ministry was terminated due to lack of funds and poor maintenance. The church had no choice but to look for another location. What they found was a step down from the comfort that they enjoyed at the previous location.

This time they moved to the Beverly Hills United Church. This church was located more than one mile from the nearest public transportation. The only access to the church was by private transportation or walking the over-one-mile distance. Not

\footnotetext{
l“'Downsview Seventh-day Adventist Church Clerk's Report: 1984" (Downsview Seventh-day Adventist Church, Toronto, Canada).
} 
surprisingly, this move made many of the members unhappy, especially on rainy days, and during the cold winter weather. As a result, several families transferred memberships to other churches. By the end of 1985, the church's membership had dropped from 181 to 146. ${ }^{1}$ To make matters worse, the loss of members meant a significant drop in income. As a result, the bus ministry which had begun again came to a sudden end.

To overcome the challenges, the church increased its evangelistic thrust. Many new souls were added to the congregation under the spirited leadership of Pastor Haskell Edwards, Pastor Steve Cassimy, Pastor Eustace Henry, and Pastor Frankie Lazarus. These men served the congregation in this same location for a total of ten years (January 1984-August 1994). By the end of 1994, the membership had grown to 240 . Weekly attendance averaged only about 60 percent of this, however. Access to and from the church on Sabbath was very difficult, especially in bad weather, and members were constantly threatening to relocate to other congregations if the situation continued indefinitely.

The Period of Church Building and Evangelism (1994 to 2004)

The period from 1994 to 2004 was one of church building and evangelism for the Downsview Seventh-day Adventist Church. During this time, the church experienced a new sense of purpose and mission. Plans were made with specific focus on the ownership of a place of worship and on church growth. The believers worked together with enthusiasm because they had one common purpose. They were united in their plans, and God blessed the Church.

1“Downsview Seventh-day Adventist Church Clerk's Report: 1985" (Downsview Seventh-day Adventist Church, Toronto, Canada). 
The Plan to Build

My assignment to the Downsview Seventh-day Adventist Church began on September 3, 1994. This came at a time of conflict for the church. The congregation was still renting worship space in the Beverly Hills United Church, where it had been meeting for ten years. My initial observations were that the church had been through a lot of disappointments due to the lack of purposeful planning. The church had been talking about building, fundraising, and spiritual growth without any real progress. I still remember the first business meeting that I had at the church. The members were very vocal in expressing their frustrations over having had to rent worship space for such a very long time.

To make matters worse, the congregation was severely restricted in its use of the Beverly Hills United Church as a place for worship. Access to the building was limited at best. Weekly church services were regularly interrupted by the landlord's use of the facility. At one point, certain privileges were withdrawn, such as the use of telephone services, and the use of the space for Sabbath lunches, afternoon programs, and other meetings. It became clear that it was only a matter of time before all privileges would be gone. To make the situation worse, the church had passed up many offers to purchase its own building, because of lack of available funds. When I became pastor, the church was in the midst of yet another struggle to decide on the purchasing of another location. Members of the congregation were feeling anxious to change location, but the funds were not in place to close the deal. Members were weary of the present conditions and there was a great sense of despair, as they watched another offer pass by.

To address this situation, a special Business Meeting was called to assess the circumstances of the church. Attendees considered three questions at the meeting. 
1. What was the current condition of the church? This was an opportunity for the church to look at the circumstances that were present at the time.

2. Where would the church like to go? This gave the congregation the opportunity to look at goals and objectives for the future.

3. What could the church do to reach its destination? The members looked at the ways and means of attaining its goals.

After looking at the first question, the members identified a number of specific problems.

1. The current worship facility was too far from public transportation, which made the members very unhappy.

2. The worship space was not suitable for Sabbath worship and fellowship because it was so frequently being used for parties, dances, or dinners on Friday nights.

3. Many people were getting tired of having to prepare the space for worship most Sabbath mornings. It was tiring to have to set up the chairs for worship and then restock them after worship.

4. The space was restricted on a weekly basis, because three other worship groups shared the church building; they sometimes even shared the same space on Sabbath mornings.

5. The church did not have enough money to purchase the desired property for worship.

6. There was no long-term strategy to secure a suitable property, should one become available. The human resources were not focused in the right direction and the financial resources were at best sporadic. 
To address these problems, the church evaluated its options. This was designed to help the congregation decide on the most appropriate thing to do. In their book, When Not to Build, Raymond Bowman and Eddy Hall offer a test for determining if a congregation is ready or not to build. They estimate that a church is ready to build when all nine statements listed in their financial test section are true. The following is Bowman and Hall's financial test followed by the authors' instructions for evaluating results.

Which of the following are true for your church? Check those that apply.

1. The regular giving in your church is strong.

2._ The giving units represent a majority of the congregation.

3. We consistently meet our budget, fully funding our ministries and staff needs.

4. Our budget includes adequate funds for intentional outreach and for meeting the needs of people in our community.

5. We teach Biblical finance for families and individuals, including an emphasis on Biblical giving.

6. The Church is out of debt.

7. In a survey the present giving units have committed themselves to an increase in their giving to cover the cost of construction and future building operation costs, so that none of the church's present ministry spending will be diverted to building.

$8 \quad$ The increase giving for future facility needs has been invested in an interest-bearing provision fund.

9. The church has invested enough in its provision fund to be able to pay cash or almost cash for the proposed building program.

If you checked statements 1 through 6 , your church is probably basically financially healthy, and by implementing the strategies of 7,8 and 9 , you should be financially 
ready to build within a few years. When all nine statements are true for your church, you pass the financial readiness test.'

The Downsview Seventh-day Adventist Church initially failed this test. The situation was grim: The church had been at its current location, already determined to be inadequate, for the past nine or ten years, and it had failed the financial test to build.

Although members of the congregation were eager to own their own place of worship, the church had been very slow to meet its commitments. A research of previous actions taken by the church showed that the members had been following inappropriate methods of fundraising. According to the minutes of the Building Committee meeting on June 14,1988 , the following proposals had been recommended to the church as plans for fundraising. "Invest present cash in buying a family dwelling, plan concerts, invest in sales of fresh fruits and vegetables, hold flee market or garage sales for fundraising, sponsor banquets, [and] harvest festival and bake sales."2

As a result of a number of these proposals, the church's savings were being drained. The programs had been poorly planned, and they lacked united support. It was clear that the church needed to reevaluate its priorities in order to create a new vision. The church needed to reorganize its priorities in order to give meaning and purpose to its ministry. According to Steven Covey, "One of the most powerful processes we've found

${ }^{1}$ Ray Bowman and Eddy Hall, When Not to Build: An Architect's Unconventional Wisdom for the Growing Church (Grand Rapids, MI: Baker Book House, 2000), 157, 158.

${ }^{2}$ Downsview Seventh-day Adventist Church Minutes, Church Building Committee, June 14, 1988, Toronto, Ontario. 
to cultivate the passion of vision is creating and integrating an empowering personal mission statement."

After more than fifteen years without a permanent place for worship, the church building committee met and decided to put three options before the congregation: (1) to purchase land for future building, (2) to purchase land with a building that could be renovated for worship immediately, and (3) to purchase a church building ready for occupancy. ${ }^{1}$ Having considered the three options, the church decided on the second: to purchase land with a building to renovate as a place of worship until enough funds were collected to build a new sanctuary. This was considered to be the most practical option of the three. For the next two years, this plan was the focus of the church. Now that the church had decided on what it would like to do, the next step was to begin to search for ways and means to reach that goal. Once there was a plan, the members believed that there were ways and means for the plan to be realized.

\section{The Strategic Plan for a New Church Building}

A plan is a process that controls the order in which a sequence of operations is to be performed. It is a detailed outline of the operation. It is a series of projected actions to realize a goal when the status quo is no longer acceptable and the re-ordering of priorities is necessary. Having taken stock of its current situation, the church needed to respond to the challenges of the future. The church decided to formulate a new strategic plan to address the situation and to move the church into the future. The church had realized that

${ }^{1}$ Stephen R. Covey, A. Roger Merrill, and Rebecca R. Merrill, First Things First, To Live, to Learn, to Leave a Legacy (New York: Simon and Schuster, 1994), 106. 
it needed a more focused approach to meeting its goals and objectives. On October 22, 1994, a new plan was introduced and voted for the church. The aim of this plan was to obtain a new place of worship within two years.

A planning committee of thirteen members was chosen to outline the ways and means to accomplish the goals of the church. As a means of preparing the church for this plan there was a call for a stewardship revival among the members of the church. This was a call based upon equal sacrifice not equal giving among the membership. From January 1995 until December 31, 1996, every member was asked to commit to a plan of systematic benevolence. Every member was asked to give a second tithe for the building of the house of God. The projected income from this plan was set at $\$ 300,000$. The funds were to be turned in each week along with the regular tithe in the same envelope.

The foundational principle behind this plan came from the building of the Hebrew Sanctuary. As we read in Exod 25:2, the Lord told Moses to "Speak unto the Children of Israel that they bring me an offering: of every man that bring it willingly." Then again, from Exod 25: 8, "And Let them make me a sanctuary that I may dwell among them." According to Exod 36: 4-7, in response "the people brought more offering than was needed." White writes that God has given us enough blessings so that we can return portions to Him.

The only means which God has ordained to advance His cause is to bless mankind with property. He gives them the sunshine and the rain; He causes vegetation to flourish; $\mathrm{He}$ gives health and abilities to acquire means. All our blessings come from His bountiful hand. In return, He would have men and women show their gratitude by

\footnotetext{
'Downsview Seventh-day Adventist Church, Building Committee Minutes, October 19, 1994, Toronto, Ontario.
} 
returning to Him a portion in Tithes and offering - in thank offerings, in freewill offerings, in trespass offering.'

Discussing the successful plan given to Moses by God, she writes:

The plan of Moses to raise means for the building of the Tabernacle was highly successful. No urging was necessary. Nor did he employ any of the devices to which churches in our day so often resort. He made no grand feast. He did not invite the people to scenes of gaiety, dancing, and general amusement; neither did he institute lotteries, nor anything of this profane order, to obtain means to erect the tabernacle for God. The Lord directed Moses to invite the children of Israel to bring their offering. He was to accept gift from everyone that gave willingly, from his heart. And the offerings came in so great abundance that Moses bade the people cease bringing, for they had supplied more than could be used. ${ }^{2}$

White further writes that when we follow God's plan of "Systematic benevolence" there "would be a constant supply in the treasury. The income would flow like a steady stream constantly supplied by overflowing springs of benevolence."’3 Regarding the ways in which we raise funds, she asks the following question: "Where in God's directions for the support of His work, do we find any mention of Bazzars, concerts, fancy fairs and similar entertainments?"4 To this question, she gives this answer: "All these methods for bringing money into His treasury are an abomination to Him. It is a spurious devotion that prompts such devising"s

The second goal of the Downsview Church's strategic plan was to acquire a place for worship by the end of 1996 . This plan was very successful. In five months, the church

${ }^{1}$ White, Testimonies, 5:150.

${ }^{2}$ White, Patriarchs and Prophets, 529.

${ }^{3}$ White, Testimonies, 3:389, 390.

${ }^{4}$ Ellen G. White, Christian Service (Washington, DC: Review and Herald Pub. Assn., 1983), 204.

${ }^{5}$ Ibid 205. 
received enough money to purchased a new place of worship. The members of the church exhibited a spirit of sacrifice and commitment, exceeding the goals set for baptism and church growth. In May 1995, the church purchased a two-acre piece of property with a small industrial building with the intention of converting the building into a place of worship. The members were greatly inspired and worked with their own hands on this building to prepare it for occupancy. On the first Sabbath of 1996, the congregation moved to its new location. This was to be the permanent home for a people that had seen many years of wondering. This was a most joyous occasion, a dream come true after more than sixteen years. The members designated the building as a starter home until a more permanent place of worship could be erected. At the end of this two-year period, the church had managed to reach most of the goals of its strategic plan. The results of this plan were so inspiring that the Church asked for the plan to continue with some modification for another three-year period.

This three-year plan (1997-1999), which was an extension of the previous plan, focused on training and equipping leaders. This plan was easier to communicate to the church members because the believers had seen the result of the last two years. They had seen the results of the first tent evangelistic series. And they had seen the purchase of a prime property in the city for the church. This new three-year plan outlined the blue print for (1) church growth and evangelism, (2) church building, (3) church leadership, and (4) church finances. What follows is a description of each of these goals.

\section{Church Growth and Evangelism}

The goal was to encourage each member to seek a deeper experience with Christ through daily Bible study, prayer, and soul-winning. To achieve this goal, the plan was 
for the local church to conduct a series of workshops and seminars to teach the members how to become more effective Christians. The training would be followed by an evangelistic series each year to teach members the practical aspects of soul-winning.

Three series of meetings were conducted as planned. The church held a tent evangelistic series in 1997 and a satellite series called Net 1998 as well as a third tent series in 1999. As a result of these, the church was blessed with more than 200 new members. This increased even more the need for a church building, which is the topic of the next goal outlined in the three-year plan.

\section{Church Building}

As the church membership continued to grow each year, it was necessary that the physical facilities be expanded to accommodate the various weekly ministries each week. With this goal in mind, a new sanctuary building was proposed to replace the present worship hall, which had, in just three years, become much too small. The plans called for the drawing and designing of a new edifice to include a sanctuary, Sabbath school rooms, offices, and storage space.

Much more need not be said regarding this goal at this point as it permeates every part of this dissertation. The next goal outlined in the plan had to do with leadership.

\section{Training and Equipping Church Leadership}

In light of the rapid growth of the church, the right person needed to be chosen and trained to lead out. The success of any church largely depends upon the right leader functioning as prophet, pastor, consultant, theologian, and finance expert. Allan E. Nelson describes leadership as "a relational process, whereby individuals grant special 
influence to one or more persons, who in turn catalyse the group to pursue intended changes." The challenge is to identify just the right kind of leader or leaders needed in a given context. Evelyn M. Huber explains that the "leadership needs of a church grow out of its planning to fulfil its mission." Thus, the first step is for a church to have a fully developed plan, including an outline of programs. Huber continues that it is then each individual "program or ministry [that] calls for leaders with particular qualifications or specialized skills." Furthermore, she continues, "the specific kind of training needed will be determined by [each] program." ${ }^{.2}$ The right person to lead out in a church needs also to be physically and spiritually fit. Church leadership requires both the physical and spiritual commitment of a person. Clearly the leader must be a theologian who is familiar with the Bible, as explained by Alan Nelson and Stan Toler, but leadership also means leading with one's "whole being" which includes the soul. One "cannot lead spiritually without a system for spiritual growth."

Aubrey Mulphur, an expert of leadership and church growth, explains that "a Christian leader is a Christian from core to crust." Hence, church leaders should be committed Christians who would be willing to put themselves under the Lordship of Christ. They should be humble and willing to become servant leaders, to serve others 49.

${ }^{1}$ Alan E. Nelson, Leading Your Ministry (Nashville, TN: Abingdon Press, 1996),

${ }^{2}$ Evelyn M. Huber, Enlist, Train, Support Church Leaders (Valley Forge, PA: Judson Press, 1975), 5.

${ }^{3}$ Alan Nelson and Stan Toler, The Five Secrets of Becoming a Leader (Ventura, CA: Regal Books, 2002), 84.

${ }^{4}$ Aubrey Malphurs, Being Leaders (Grand Rapids, MI: Baker Books, 2003), 14. 
because of Christ. Mulphur continues that "Christian leaders are servants with credibility and capabilities, who are able to influence people in a particular context to pursue their God-given direction."'

As the Downsview Church congregation grew, the church body included youth, young adults, children, and older persons. The church needed a new type of leadership. It needed people who could lead the children, chair the finance committee, and counsel the youth. It needed others who could care for the needs of the elderly, and still others with typing skills, computer skills, and a host of other skills. The church needed leaders who could interpret the signs, and make sense of the times. Robert Dale emphasizes that the new "information society calls for leaders who [can] process data, recognize the pattern, and interpret situations in fluid environments. Today's effective leaders must zoom nimbly down the information superhighway while dealing deftly with high-speed change." 2

Leading the Downsview Church congregation through the process of building a place of worship required certain leadership skills. The key challenge was to identify these skills. It is currently common to organize leadership styles into the following four categories: Democratic, Autocratic, Authoritarian, and Laissez-faire. While certain aspects of these types of leadership can be helpful in a church setting, a church's model for leadership really should come from the word of God. To guide the Downsview Church though the process of achieving its desired goals for church growth and a new

\footnotetext{
${ }^{1}$ Ibid., 33.

${ }^{2}$ Robert D. Dale, Leadership for a Changing Church: Charting the Shape of the River (Nashville, TN: Abingdon Press, 1998), 17, 18.
} 
church building, four biblical styles of leadership were identified and followed: (1) Prophetic Leader, (2) Pastoral Leader, (3) Pastoral Consultant, and (4) Leader as Theologian.

The Prophetic Leader looks at the overall program for the church, interprets the process necessary to achieve desired goals, and points the church membership toward the future. Just like the prophet who speaks the will of God, the Prophetic Leader must be open to God's will. This leader must look at the past, the present, and to the future before making decisions. The Downsview Church needed such a leader, one who could see the big picture as he sought to guide the church in the path that would help the process of building construction and church growth. As the leader during this period, I needed to make the case to the members for the construction of a building, and I needed to interpret the plans in harmony with God's word.

During the process of growth and church-building construction, the Downsview Church also needed a Pastoral Leader. This type of leader is essential in guiding and caring for the needs of a church. Like a good physician, the leader needs to know how to care for the church. As Charles Olsen describes, "A good physician is intimately acquainted with the stages of physiological development and deterioration. The doctor is conversant with birth, coordination, adolescence, vital signs, injury, trauma, disease, infection, health, decay, and death. With this knowledge, he or she will treat the patient within the life stage and situation that is observed."' So must be the Pastoral Leader. Lyle

${ }^{1}$ Charles M. Olsen, Cultivating Religious Growth Groups (Philadelphia, PA: Westminister Press, 1984), 25. 
Schaller refers to the pastor's role as being like a "number one medicine man"' who acts as the chief administrator of the church. The Pastoral Leader visits the members and knows their spiritual and physical conditions. White describes him as a shepherd: "As the shepherd of the flock he [the minister] should care for the sheep and the lambs, searching out the lost and straying, and bringing them back to the fold. He should visit every family, not merely as a guest to enjoy their hospitality, but to inquire into the spiritual condition of every member of the household."

The Pastoral Leader must have a comprehensive knowledge of the spiritual health of the members so that the right spiritual lessons can be taught. This was especially important during the time of building construction at the Downsview Church. As the leader, I needed to know how to perform certain types of evaluation, and I needed to be prepared to make critical decisions at the right times. It was also vital that I help encourage every church member to become involved in the ministry of the church during such a time.

The next leadership style, the Pastoral Consultant, entails a leader who seeks the opinion or advice of others in order to make a decision on a plan or action. The Pastoral Consultant plans meetings with professionals and gathers technical advice on important issues. During the building process at the Downsview Church, I also worked as Pastoral Consultant, seeking the opinions of the builders and trades involved with the project, and I acted in an advisory role to the church body. Charles M. Olsen explains that as "a

\footnotetext{
${ }^{1}$ Lyle Schaller, The Multiple Staff in the Larger Church (Nashville, TN: Abingdon Press, 1980), 106.

${ }^{2}$ White, Evangelism, 346, 347.
} 
Pastoral Consultant, you can help group members share their feelings, establish communication, forgive a wrong, explore options, and make new decisions."'

As the new building began to emerge and take shape, many church members began to ask questions regarding the building itself. These questions ranged from inquiring about size, height, lighting, color coordination, and occupancy permit, as well as many others. Proper answers to these questions needed to be provided. Otherwise, there was the risk that people could become disgruntled with the project and discord could spread among members. To prevent such conflicts, I made sure that meetings were held every week with the experts in order to clarify what was being done. I then made sure that this information was communicated to the church and that members were kept updated on whatever changes were necessary as well as the general progress of the work. This information was first channeled through the various committees before it was communicated to the church.

The building of a church has religious meanings. It represents certain values and beliefs held by many. A place of worship is constructed differently from a place of business or a family home. The Leader as Theologian helps the people of the congregation to connect their real experience with the Bible and the place for worship. In his book, Cultivating Religious Growth Groups, Olsen writes that "as a theologian, the Pastor also should be skilled in the process of enabling lay-persons in small groups to Theologize." This means helping them "to connect their real life experience with the Biblical story, while looking for meaning, values, and faith affirmation."2 The Leader as

${ }^{1}$ Olsen, 28.

${ }^{2}$ Ibid., 29. 
Theologian will explain to members the meaning of the pulpit in the center of the platform or the meaning of the communion table, the meaning of the baptistery, the cross, or the stained glass windows. Hence, as people come to worship, they can connect their faith to the Bible and the actual place of worship.

We now turn to the fourth and final goal outlined in the three-year plan.

\section{Church Finance}

The issue of leadership is by necessity intertwined with the issue of church finances. The purchase of new property, the process of building renovation, and the necessary added maintenance all increased the financial burden on the Downsview Church budget. Church members were now faced with a new financial reality. They needed faithful stewards. Good leadership is necessary to teach the church the principles of Christian stewardship. The church needed leaders who would faithfully support the ministry of the church through systematic benevolence. The church needed a leader who could both teach and train other leaders to be faithful in systematic benevolence. First, he needed to be sure that he lived a life in accordance with what he wanted to teach others. This was my challenge with respect to finances as I led the church on its journey of church building.

\section{Communicating the Vision to Church Members}

This section focuses on how the vision for the church was communicated to the membership. To have a vision is to have a sense of discernment. This discernment helps the church to see what it is at present and what it can become in the future. It helps the church to know what it can do best and explains how the mission of the church will be 
done. Vision helps to prevent flaws. Prov 29:18 reads, "Where there is no vision, the people perish." Vision targets specific goals for accomplishment. It guides the activities of people to keep the focus on a specific goal. It tells how the church can best minister in its context. Thom Rainer puts vision into context as follows: "Every church has a unique personality. That personality reflects the members' gifts, passions, and strengths. A wise leader focuses the efforts of the church according to the uniqueness of the church. The vision articulates how the church's unique personality can best minister in its context and community."'

A impression of a vision must be deepened through repetition. Before the vision can be realized, it must be communicated to all the people. Lack of proper communication can cause frustration, discouragement, and conflict in the process. To avoid misunderstanding, Rick Warren advises that "vision and purpose must be restated every twenty-six days to keep the church moving in the right direction."2 During the building process at the Downsview Church, we used several methods to communicate the vision to the members. We published newsletters each month to remind members of their commitments. We used the weekly church bulletin to help keep the information fresh in the minds of the congregation. We made periodic verbal announcements to give life to the plans. As the plans were laid out, various committees were selected to study various aspects of the work. Through these committees, information was communicated to more and more members.

\footnotetext{
${ }^{1}$ Thom Rainer, High Expectations: The Remarkable Secret for Keeping People in Your Church (Nashville TN: Broadman and Holman Publishers, 1999), 150.

${ }^{2}$ Rick Warren, Purpose Driven Church: Growth Without Compromising Your Message and Mission (Grand Rapids, MI: Zondevvan Pub. House, 1995), 111.
} 
I further focused on communicating the vision through sermons. The weekly sermon is a tremendous way to communicate to the church members. The Bible contains powerful reasons why it is important to build a church for God. I used my sermons to communicate biblical truths related to church building in order to inspire members' support. The biblical principals upon which I focused are outlined in chapter 2 of this dissertation. Teaching these principles, passionately and with enthusiasm and conviction, was an effective way of communicating the vision to the people. These sermons were designed to show that the vision of the church was alive and Bible-based.

The communication of the vision through committees also played a key role in the process. The formation of various committees was designed to get most of the church members taking part in the planning process. Being members of committees allowed people to take ownership of the project. It also led to their more active solicitation of participation from others in the community of believers. The committees were instructed to carry out certain functions and to guide in the process of the planning and construction. The many committees that were formed included the building committee, the finance committee, the decorating committee, the music committee, the landscaping committee, and the maintenance committee. These groups were important, as Mack Tennyson explains: “A spirit-filled group makes more reliable decisions than a Spirit-filled individual. A group can find God's will for a church better than an individual."” Each committee was given the responsibility of studying a particular task, thus enabling the people to get a better understanding of the importance of each ministry to

${ }^{1}$ Mack Tennyson, Making Committees Work (Silver Spring, MD: Ministerial Association General Conference of Seventh-day Adventists, 1984), 8, 9. 
the church. As each committee studied the problems associated with the task that they were given, they would also suggest the course of action to follow to solve the problems. They also could suggest courses of action necessary for reaching the goals set by the church. Through the various committees, the church was led to find God's will, and to discover that God placed more value on people rather than on programs.

Churches must take care when working with committees, however. While committees are a great way to get more people participating in the work of the church, committees can also slow down the work of the church. As Peter Wagner cautions, "the more boards and committees in a church, the more chances for bickering, infighting and conflict of interests. They slow down the decision-making process, sometimes almost to a standstill." In order to decrease the possible negative side effects of committees, great care should be exercised in the size and number of committees. The number of committees should be kept at a minimum so that their work does not hinder the growth of the church.

While we tend to instinctively think of conflicts as a bad thing, this is not always the case. While people tend to hate conflict, not all conflicts are bad. In fact, conflict can help the church to think more clearly about its goals and objectives and to find more creative means of communication. Furthermore, when a church anticipates, it will be better prepared to deflate it when possible and to better use it for the good when necessary. This is the approach we took at the Downsview Church. During committee meetings and church business meetings there were those who constantly opposed the

${ }^{1}$ C. Peter Wagner, Your Spiritual Gifts Can Help Your Church Grow (Ventura, CA: Regal Books, 1994), 221. 
views of others, but we were prepared for this. As the pastor, I was aware that conflicts could be anticipated if I did not consult certain members about a plan before going before certain committees. I was aware that I was always under scrutiny. Members watched for every opportunity to oppose and object to certain decisions. Speed Leas points out the results of a research on pastoral firings by the Alban Institute. The study concluded "that after the completion of a new building, clergy were vulnerable to firing." Based on my own experiences, this is not surprising.

During the Downsview church-building project, I discovered that communicating the vision of the church through conflict posed a major challenge. This was especially true with respect to the building committee. Nonetheless, each conflict offered a unique opportunity to clarify points of concern. The conflicts at our church stemmed from different points of view regarding the project. Divergence existed even with respect to the value of the project itself. One group of individuals felt that we should not be spending our time and resources building a new sanctuary because Jesus would be coming soon anyway. Another group thought that we should be using the money to feed the homeless. Others thought that we should continue to rent until we had all the necessary money in hand. There were others who supported the building project but who wanted me to consult them on every matter before I would speak to the building committee. There were people who wanted to have the last word on matters such as color of carpets, the kind of bricks used, color of paints, or types of doors and windows. Everyone believed that he or

\footnotetext{
${ }^{1}$ Speed Leas, The Ten Most Predictable Times of Conflict, quoted in Marshall Shelley, Leading Your Church through Conflict and Reconciliation (Minneapolis, MN: Bethany House Publishers, 1997), 49.
} 
she had the right answer to any given problem. Everyone in the church with a particular opinion did all that was possible to communicate that view.

Prov 15: 28 reads, "The mind of the righteous ponder how to answer, but the mouth of the wicked pours out evil things" (RSV). It is imperative always to be studying how to give the right answers to those who find occasion to object to the vision of the church. Quite often, many of those who criticize the church actually need work to do. Finding a way to put then in charge of some work can make a significance difference in their level of support for the project. Fred Smith explains that this is a way of turning critics into coaches.

A good critic and a good coach both see what is wrong. They see for different reasons, however. The critic sees the problem to point it out and establish his authority or expertise, while the coach sees the problem in order to work on it and improve it. I believe that with proper care most critics can be turned into coaches. What we normally think of as liabilities then become assets. ${ }^{1}$

Disagreements and the entire process of building a new church led to some unexpected losses and challenges. Surprisingly, many who had been supporting the church building project for a period of up to a year and who had been faithful to the work, ended up walking away from the church during the midst of the project. These were people who had longed for a place of worship, and just at the time when the dream was about to be realized, had transferred their memberships out of the church. This was a difficult and unexpected challenge for all those who had remained behind. Nonetheless, those who walked away most often continued to hold that the church was doing the right thing. Even in disagreement, the vision of the church was always clear.

\footnotetext{
${ }^{1}$ Ibid, 263.
} 
In light of this and other challenges stemming from the process of change the church was undergoing, it was essential that members were there to provide encouragement to one another. The Apostle Paul offers advice on comfort: "Wherefore comfort yourselves together, and edify one another, even as also ye do" (1 Thess 5:11). Expressions of appreciation and sincere commendations were regularly given to encourage members who did outstanding work. Too often, those who have given time and energy to the church are taken for granted. We made sure to give recognition for jobs well done in a number of ways, including through the giving of certificates, flowers, and other gifts. Encouragement is one of the strongest motivators we have in our sphere of influence. Hans Finzel describes giving people encouragement for a job well done as being like oxygen to the soul.

Jesus spoke of its importance when in a parable a master said to his servant, "Well done, good and faithful servant! You have been faithful with a few things; I will put you in charge of many things. Come and share your master's happiness!" (Matt 25: 21) Leadership is very much about supplying those oxygen lines to our followers. And I have never met a leader who did not also need encouragement along the way.'

When church members are highly motivated, they feel good about their work and about themselves. Motivation inspires them to do more than they would do under ordinary circumstances. It also makes them more willing to do work in the future. The importance of people needing encouragement, especially when they do positive things, is difficult to overemphasize. When people know that they are appreciated for even the little things, they will do even greater things.

\footnotetext{
${ }^{1}$ Hans Finzel, Empowered Leaders: The Ten Principles of Christian Leadership (Nashville, TN: Word Publishing, 1998), 54.
} 


\section{Summary}

For many years, the Downsview Seventh-day Adventist Church had been renting places for worship. The congregation first met in a community center, but very soon found the facility inadequate for worship. The congregation made various moves into school gymnasiums, but each time still the accommodations were not suitable for worship. Renting church facilities for worship proved to be problematic at best. The congregation learned that preparing to build a place for worship required focused planning. Initially, because there was no purposeful plan, there was no definite direction and no clear sense of a common goal. It was only when the church developed a plan of action that the people became serious about the building of God's House. With this plan, it took the church less than two years to do what it had been trying to do for sixteen years. Chapter 4 focuses on the strategies that were used in the construction of this building. It explains how things were accomplished with the help of God. 


\section{CHAPTER 4}

\section{STRATEGIC PLAN FOR BUILDING A PLACE OF WORSHIP}

The building of a place of worship was a major undertaking for the congregation of the Downsview Seventh-day Adventist Church. Getting the job done required the most advantageous planning. To accomplish this major task, a strategy was developed that would define how the task would be accomplished. Discussing the raising up of a church, Ellen G. White writes: "When a church is raised up, the members are to arise and build. Let the newly converted ones, under the direction of a minister who is guided by the advice of his fellow minister, work with their own hands, saying, We need a church and we must have a church and will each do our best in helping in the building."'

The job of completing the new Downsview Church building was completed thanks to the mobilization of the pastor and the lay people, working together towards a common goal. The purpose of this chapter is to outline the strategy for transforming into action the church's vision to construct a place of worship. My hope is that the detailing of how this work was accomplished can provide useful guidance to other pastors and lay people who aim to work together effectively in ministry towards a common goal.

\footnotetext{
${ }^{1}$ White, Evangelism, 379.
} 


\section{The Management Strategy}

Jesus used the best management strategy when he was here on earth. He called and empowered twelve disciples to preach the gospel (Matt 10:1-15). Later, he gave the committee of twelve men the authority to baptize and make disciples of others (Matt 28:18-20). In the world of business, people use well-formulated strategies to accomplish tasks. Paul Dobson and Ken Starkey explain that "the key strategic issue is to put in place a system of management that will facilitate the capability of the organization to respond to an environment that is essentially unknowable, unpredictable and, therefore, not amenable to a planning approach."' The committee is one such management system.

For years, the Seventh-day Adventist Church has used committees to conduct most of its business. Regarding church management, White counsels that "no one man is to be a controlling power, a voice for the whole. Proposed methods and plans are to be carefully considered so that all the brethren may weigh their relative merits and decide which should be followed."2 The blue-print for the strategy is harnessing the internal energies of the church so that no one person does the work alone. Working with committees can be a great advantage, when the right people are chosen with the right skills.

Using committees to plan strategically and then to implement these plans is a key part of carrying out the purposes of an organization. Aubrey Malphurs, an expert in

'Paul Dobson and Ken Starkey, The Strategic Management Blueprint (London: Blackwell Publishers, 1993), 1.

${ }^{2}$ White, Testimonies to the Church, 7:259. 
church growth, lays out five reasons why we need to plan strategically:

1. Strategy accomplishes the mission and vision.

2. Strategy facilitates understanding.

3. Strategy provides a sense of momentum.

4. Strategy properly invests God's resources.

5. Strategy displays what God is blessing.

As a result of our strategic planning at the Downsville Church, committee members were able to keep the focus on the vision and goal of constructing a new church sanctuary. Members were able to consult each other before decisions were made for the project. Robert E. Firth offers one major reason for using committees in the Seventh-day Adventist Church. His argument is that "people do not trust one person to make major decisions that will affect their lives."2 While no one person should take on the huge task of church building all alone, to get people to work together requires patience and careful planning.

In planning the construction of the new Downsview sanctuary, several committees and subcommittees were formed and each was given specific tasks to perform. Members of the various committees were people with construction experience, and lay persons who gathered information, sorted information, identified problems, searched for solutions, identified options, and analyzed the situation before making decisions. Committee members were responsible for putting into place a structure or

${ }^{1}$ Aubrey Malphurs, Advanced Strategic Planning: A New Model for Church and Ministry Leaders (Grand Rapids, MI: Bakers Book, 1999), 15.

${ }^{2}$ Robert E. Firth, Guidelines for Committee and Board Members (Washington, DC: Review and Herald Publishing Association, 1973), 30. 
process that would facilitate the capabilities of the church in light of the given financial limitations and the time-line for the project. The committees were the driving forces behind the building project. They were the means for getting the entire membership involved in the work that was to be done. Not only were the committees set up to guide the building project, but they also had the authority to recommend the addition, elimination, or modification of programs all with the goal of making sure that the mission of the church would not be hindered during the construction process.

It seems important at this point to focus on how committees function. Committees have long been used by churches as a strategy to get difficult jobs done. In 1996, for instance, the Catholic Church set up a special committee to address the issue of the church's relations with African Americans.' In 1998, the Evangelical Lutheran and Catholic Churches used committees as a strategy toward dialogue on unity between the two groups. ${ }^{2}$ In 1990, The United States Government used a committee as a strategy to reform the Medicare System. ${ }^{3}$ The formation of committees has always helped to organize the workforce to accomplish difficult tasks. In the Downsview Church's building project, each committee was given a job description so that the members could be more active and fully participate in the work of building the church.

${ }^{1}$ Monsignor Dennis M. Schnurr, "Keep Your Hand on the Plow," in Committee on African American Catholics National Conference of Catholics Bishops (Washington, DC: United States Catholic Conference, 1996), 1.

${ }^{2}$ Monsignor Dennis M. Schnurr, "Evangelical Lutheran-Roman Catholic Dialogue, Quest for Visible Unity, Lutheran—Roman Catholic Committee" (1998), 1.

${ }^{3}$ Medicare: A Strategy for Quality Assurance, 2 vols. (Washington, DC: National Academy Press, 1990), 1:1. 
The committees helped to create a more positive work environment in the church. They helped to choose the bricks, the color of paint, the carpeting, the flooring, the lighting, the pews, the drapes, and the baptistery. They chose the layout of the building, they did the cleaning up of the site each week, as well as the landscaping, the gardening, and so on. This approach helped to prevent any one person from making unwise decisions.

The building and finance committees were set up to give leadership to the program. Other subcommittees were charged with carrying out specific tasks for the work of the church. Each committee and subcommittee played a vital role in the planning and implementation of the various aspects of the construction of the new building. They made sure that other programs of the church were kept going during the construction period. They were able to provide input into how the new facility could meet their needs. They identified the needs of the church and how to incorporate these needs into the planning process. They gave suggestions and provided answers to concerns regarding the project. In so doing, I, as the pastor, as well as the architect and the builders, was not the only ones providing solutions to problems. The people took ownership of the project from the start to finish.

\section{The Right Location for the Church Building}

Choosing the right site location was one of the first major considerations in the planning process. According to the Seventh-day Adventist Minister's Handbook, three things are of prime importance when it comes to the building of a place for worship: "the 
first is location, the second is location, and the third is location." As the building committee, charged with making the final decision regarding location, began its work, there were several questions that it had to answer in relation to the designated site. Was the site marked off or designated for the intended purpose? Was the surrounding area favorable to a place of worship? Would the church be able to conduct its ministry without interference from other activities in the area? The Seventh-day Adventist Church considers this to be of great concern. In planning for both church and school buildings the following guidelines are set out for the churches. "Wherever possible, a site should be selected amid quiet surroundings in a desirable neighborhood, with space large enough for a lawn, shade trees and flowers." ${ }^{2}$ With these guidelines for site selection in mind, the committee looked at several sites but found that only three were close to the guidelines. Committee members looked at three sites, and the final decision was made at a church business meeting. After having visited each site, members were asked to come to a members' meeting to present feedback and provide comments regarding each site.

\section{Details of the Sites under Consideration}

More than just the building committee members visited the sites. All the members of the church had the opportunity to walk through each site with the real estate agent and view the facilities, asking whatever questions they wished. Table 5 offers a summary of the various concerns that were addressed at each site. The committee looked at whether

${ }^{1}$ Seventh-day Adventist Minister's Handbook (Silver Spring, MD: Ministerial Association General Conference of Seventh-day Adventists, 1997), 191.

${ }^{2}$ Seventh-day Adventist Church Planning, Church and School Buildings (Washington, DC: Review and Herald Publishing Association, 1953). 
the site was visible from the main transportation lines in the city, and whether people would be able to gain easy access to and from the site as they passed by. It considered the space for parking on the site and whether there was easy access to the major highways.

They also considered zoning and the possibility for future growth.

\section{TABLE 5}

EVALUATION OF SITES

\begin{tabular}{lccc}
\hline & $\begin{array}{c}\text { Site \#1 } \\
\text { Eddystone }\end{array}$ & $\begin{array}{c}\text { Site \#2 } \\
\text { Islington }\end{array}$ & $\begin{array}{c}\text { Site \#3 } \\
\text { Bakersfield }\end{array}$ \\
\hline Visibility: Can people passing by see the site? & yes & yes & yes \\
Access: Can people walk to the site? & yes & yes & yes \\
Will there be sufficient parking on site? & no & no & yes \\
Access: Is it near public transportation? & yes & yes & yes \\
Zoning: Is it zoned for place of worship? & no & yes & yes \\
Neighborhood: Close to membership? & yes & no & yes \\
Easy access to and from major highways? & yes & yes & yes \\
Required environment assessment? & yes & no & yes \\
Is there possibility for future growth? & no & no & yes \\
Is renovation required before occupancy? & yes & yes & yes \\
Is the price reasonable according to budget? & yes & no & yes \\
What is the asking price? & $\$ 500,000$ & $\$ 1.2 \mathrm{Mil}$. & $\$ 600,000$ \\
\hline
\end{tabular}

The following is a brief summary of each site with the advantages and disadvantages.

The first site was located at 95 Edystone Drive, in North York, Ontario. This was a commercial building for sale. It was close to a residential neighborhood and had good access to public transportation. Many members were in favor of this location because of its close proximity to the neighborhood. The problem was that it was not zoned for a church, and it was reasonable to conclude that it would not meet zoning requirements because of the size of the parking lot. Also, the building was in great need or repair. The 
preliminary figures suggested that the cost of the repairs could be more than the purchase price of the building.

The second site under consideration was located at 87 Elmhurst Avenue, in Rexdale, Ontario. This site consisted of a large church building for sale. It had all the necessary features, such as access to public transportation, good visibility, pews, organ, and offices, in addition to many other accessories. The building was ready for immediate occupancy. The negative factors included that the sanctuary building needed minor repairs and the parking space was insufficient for the size of our congregation. This problem could have been solved, however, as additional space was available for rent from nearby neighbors. Another problem was more difficult to address. The church was located outside of the neighborhood that served our congregation. Furthermore, it was located in a territory served by three other Adventist churches. Adding to these concerns, the cost of the property was beyond our church's set budget range.

The third site under consideration was located at 37 Bakersfield Street, North York (a city suburb of metro Toronto), Ontario. This was a two-acre parcel of land with a small industrial building, located in an area zoned for places of worship. It had space for adequate parking, was ideally located, and had easy access to public transportation. Furthermore, the price for this property was within our budget, and the prospect for future development was good. We saw the possibility of having tent evangelistic meetings in the center of the city, a school, a day-care center, and community health fairs. After much prayer, the church body made the decision in business session to purchase this site. 
Important Issues to Consider When Selecting Location

The property chosen for the new church location measured 227 feet by 338 feet. It was located in an industrial area, close to public transportation, and close to two major freeways. Before an offer was made to purchase this property, the church contacted the City Planning Department to verify that the property under consideration really was zoned for a place of worship. Because this site was located in an industrial area of the city, the City Planning Department gave proper approval in advance of purchase. A search of the city's by-laws indicated that the property met the minimum distance between places of worship and the number of places of worship per street block. The bylaws read as follows: "A maximum of one place of worship shall be permitted on each block. The minimum distance between lots with a place of worship shall be $304.8 \mathrm{~m}$ ".' Another important concern was the floor space requirement. The by-laws regarding this instruct that "in all industrial zones the size of a place of worship shall not exceed 2,787 sq. m. of gross floor space."2 The zoning by-laws also include regulations governing parking. The on-site parking requirement was " 1 space per $4.7 \mathrm{sq} \mathrm{m}$. of floor area of main worship area, or 1 space per $21 \mathrm{sq} \mathrm{m}$. of gross floor area, whichever is greater."

Gathering all necessary information before designing the building itself helped to determine the gross floor space that would be permitted on the site. It is important for church planners to keep in mind that churches are not exempt from the law. They are

${ }^{1}$ City of Toronto, Urban Planning and Development Services (Toronto: City Planning, Policy, and Research, 2003), Section 6:23.

\footnotetext{
${ }^{2}$ Ibid., 6:24.

${ }^{3}$ Ibid., 6A:6.
} 
only allowed to be built in certain areas of the city. Acquiring land or building for the purpose of establishing a place of worship must fit within the city or municipality bylaws. Buying land for places of worship in a city, without checking into the by-laws and zoning requirements, could result in the refusal of a building permit along with lengthy legal battles.

Another important step to take before designing the building itself is an environmental assessment. This consists of an historical review of the use of the property. The purpose of this assessment is to determine if hazardous materials and/or chemicals have been stored at the site. Before an offer of purchase is made on any site, it is extremely important to do this kind of assessment. This costs some money up front, but it is certainly less costly than to spend millions on a site that will cost ten times as much to clean up. The environmental assessment we conducted on the site looked for materials such as asbestos, urea formaldehyde foam insulation, lead, pesticides and herbicides, fiberglass, PCB's and radon gas, and other harmful substances. The environmental assessment was done in two phases before the building permit was issued. This environment test fortunately revealed that there was no hazardous material on the site.

An issue of importance to members of the church's building committee was knowing whether the site had certain public services available. Ordering new services to a site for development can be very costly for builders. Upon investigation, we found that the site had access to public utilities, such as water, light, sewer, telephone, and gas. The roads that led to the site were paved and in very good condition. The availability of these services at the site made it a lot easier for the church to carry out its mission without incurring extra cost. 
Assuring that there will be adequate parking space is of key importance in site choice for a church building. A survey of most of the older Adventist churches in the greater Toronto area frequently revealed a parking problem. Several of these properties were in fact purchased from congregations that had sold precisely because of insufficient parking space for their members. The General Conference Building Committee Guidelines offer the following advice with respect to parking space:

In rural and in some suburban areas where automobile transportation becomes a necessity, the parking area should provide approximately one space for every three persons seated in the Sanctuary. In Urban and Metropolitan areas, the ratio should be adjusted according to the availability of land and public transportation. Be sure to consult local parking space requirement code.'

Downsview Church members wanted to be sure that they and their visitors would have access to parking, so that they would avoid fines for illegal parking on city streets when they came for worship. In the case of our location, having adequate parking on site would also help to relieve congestion on the city streets. The available parking space even helped to determine the size of the building and floor space. Street parking in urban areas has a serious impact on the flow of public transportation and the movement of emergency vehicles in the area. This is thus an important consideration for church site choice.

One final issue of great importance to the members of the Downsview Church was access to public transportation, such as busses, streetcars, or trains. It was important to consider how easy it would be for members to take the public transportation to church. Would the new building be located on the major transit lines? Could physically disabled

'Seventh-day Adventist Church, Recommendations for Building Planners (Washington, DC: Building Plans Committee, 1991), 6, 7. 
people easily arrive at church using public transportation? Would those who came to the church find easy access into the building? Was the building accessible to those who were physically challenged? Would the building be accessible by steps or ramps?

\section{The Building Strategy \\ The Committee Approach}

As explained in chapter 3 , while the committee approach can be very successful, there are also potential pitfalls. Writing about the disadvantages associated with having committees, Mack Tennyson explains that committee meetings can be "emotional cauldrons and can stunt the growth of spiritual fruit. Emotions and pride can run strong during the meetings. Combine these with the pressures of decision making and it's no wonder that meetings can be a battleground." If these problems are not handled with love and care, this they can hinder the progress of the work. Tennyson outlines other potential pitfalls to the committee process: "Committees have negative aspects. They are expensive and frustrating. They can make bad decisions and lack accountability."2 If there is a lack of commitment on the part of committee members, this can slow progress of the work.

In my experience working with church committees, I have found several things that can affect the performance of committee members. A lack of attention to planning details can significantly increase the cost of the project significantly. If committee members are overworked and burned out, the work could be delayed. If insufficient time

\footnotetext{
${ }^{1}$ Tennyson, Making Committees Work, 16.

${ }^{2}$ Ibid., 18.
} 
is given to committees, bad decisions can result. If committee members fail to follow up on decisions made, time and money can be lost. Conflict between members of the committee can lead to bad decisions without accountability. Excessive talking about what needs to be done, instead of doing the real work, leads to frustration. In such cases, personal emotion and pride can overrule good judgment. Poor attendance by the chairperson can lead to loss of time. I found that any of the above can put the work of the committee in danger.

\section{Formulation of the Building Strategy}

Once the site was purchased, the building committee along with the pastor and the finance and planning committees began work on developing a strategy for building. Since we did not initially have sufficient funds to complete the construction of the new sanctuary, we made the decision to divide the project into two stages: the starter home and the new sanctuary stages.

During the starter home stage, the congregation would occupy a small building on the site where it would conduct all church activities. During this stage, we would fully utilize the space in the industrial building for worship. This rectangular building with dimensions of 60 feet by 80 feet had a seating capacity of 300 members. The lay people were excited to begin renovation of this building to be used for worship services. It was inspiring to see men, women, boys, and girls coming out each week to help in the renovation work. Every Sunday, church members came out to work on the project until the building was ready for occupancy. It took four months to get the job done. The first worship service was held on the first Sabbath of January 1996. Having rented worship space for more than sixteen years, the congregation experienced great joy over taking 
ownership. Converting an industrial complex to a place of worship was a real challenge. Facing this challenge elicited great motivation in the believers. It gave the members the inspiration to do something bigger than their dreams. Each week the plan of a future home was kept before the congregation. The information was presented in various forms: through sermons, through announcements from the desk, and through newsletters and bulletin items. Space in the newly renovated building was limited at best. This helped inspire the congregation for the next stage of the project. By 1997, the membership of the church had outgrown the capacity of the building. We continued to plan new initiatives such as tent evangelism and Bible seminars with the goal of increasing financial contributions and church membership.

Every year, evangelistic meetings were part of a strategy to increase the church membership. The growth that resulted from these meetings inspired both old and new members alike to contribute to the new building project. Table 6 provides information on the various evangelistic meetings planned from 1995 to 2001 .

\section{TABLE 6}

EVANGELISTIC SERIES (1995-2001)

\begin{tabular}{lll}
\hline Date and Year & Series & Evangelist \\
\hline Apr 8,1995 & Reach out for Life & Dr. V. George Kerr \\
Aug 2,1996 & Search for Truth & B. Lenroy Robinson \\
July 25,1997 & Victory in Jesus & Redverse Philbert \\
Oct 9,1998 & Net 98 Next Millennium & Dwight Nelson \\
July 16, 1999 & Footprints of Jesus & Glen O. Samuels \\
Sept 9,2000 & Net 2000, The Midnight Cry & Kenneth Cox \\
July 20,2001 & Amazing Love & B. R. Campbell \\
\hline
\end{tabular}


There were other advantages to this starter-home strategy. First, it prevented the church from leasing space for worship while at the same time paying a mortgage on the new site. Because the church was meeting on the site, it did not have to pay the municipal taxes. The yearly tax on this prime location alone was $\$ 39,000$. Second, occupying the site was a weekly reminder to the membership of the blessings of God. Individuals saw what God had done and the possibility of what he can do in the future. In the end, the plans were coming together successfully and this increased the desire for a new and larger sanctuary with better facilities to meet the growing needs of the church. Table 7 details the numerical and financial growth of the church from 1994 to 1998.

TABLE 7

CHURCH GROWTH AND TITHE TRENDS (1994-1998)

\begin{tabular}{ccc}
\hline Year & Membership Growth & Tithe Growth (Canadian Dollars) \\
\hline 1994 & 240 & $\$ 195,700$ \\
1995 & 282 & $\$ 209,672$ \\
1996 & 325 & $\$ 209,936$ \\
1997 & 370 & $\$ 247,991$ \\
1998 & 410 & $\$ 288,760$ \\
\hline
\end{tabular}

Financial Strategy for Construction of the New Sanctuary

Good financial management was vital to the successful completion of the construction of our new sanctuary. During the time that the Downsview Church was meeting in the starter home, plans were made for the building of the new sanctuary. It would be built adjacent to the starter home building. Five years after occupying the starter home, the work began and a new foundation was laid. The space in the starter home had started to be too restrictive, and I had used this to help mobilize the lay people 
once more to move on to the next phase of the project. Before moving forward, we had conducted an assessment of the current situation, to determine if the time was right to start the next stage of the project.

\section{Building Committee Report}

Before a determination was made to start the project, the building committee presented the following report to the church. The report outlined six major areas of concern that were lacking in the church facilities.

1. There was a lack of classroom space for children Sabbath school classes. There were more children coming to church than the space available for Sabbath school classes.

2. Worship space was too small for attendance. There was overcrowding in the church services.

3. There was insufficient space for the baptismal service and the communion service.

4. The facility for worship was operating beyond its capacity to meet the growing needs of the congregation.

5. There was no fellowship hall to provide social interaction for church members.

6. The present facility was far from the street line, and was not visible to the public. ${ }^{1}$ $11,2002$.

${ }^{1}$ Downsview Seventh-day Adventist Church, Building Committee Report, May 
Although there were still financial challenges, it was decided that a new structure was needed to meet the challenges of the church. This was a great opportunity for the members to unite behind a significant task with the hope that the faith of the members would increase.

A key step in this process was setting up the financial plan for the project, and the first step in setting up the financial plan was to set up a system of internal control over funds. As Mack Tennyson explains, this is not a difficult process. "The first rule of setting up control is that all payments must start with a written request giving the reason for the request, which fund to charge, and whom to pay. These requests are useful later if someone questions a certain payment and the treasurer has forgotten why it was made."' Once the system of internal control was in place, the finance committee began assessment of the financial trends in the church. An outline of the financial plan grew out of this process. The plan included the following:

1. Monitor the income and expenses of the church, to determine certain trends.

2. Assign a budget for every department of the church to determine their plan of income and expenditures.

3. Provide continuous, up-to-date information to the church regarding the building project.

4. Promote the control of financial expenditures.

5. Seek to obtain additional financing when required from appropriate sources.

6. Advise the church on the financial implications of major decisions.

'Mack Tennyson, Church Finances for People Who Count (Silver Spring, MD: The Ministerial Association, General Conference of Seventh-day Adventists, 1984), 24. 
7. Keep all the financial records required by the church, filing all receipts and payments that have been made.

As soon as this plan was formulated, the building committee met and then presented a report to the church. Their report showed the giving potentials of the church for the future. Table 8 gives the total offerings received for the local church budget as well as the incoming tithes from 1998 to 2004.

TABLE 8

CHURCH GROWTH AND TITHE AND OFFERINGS TRENDS (1998-2004)

\begin{tabular}{lccc}
\hline Year & Membership & Tithe in \$ & Church Budget in Canadian \$ \\
\hline 1998 & 410 & 288,760 & 161,634 \\
1999 & 366 & 289,507 & 144,132 \\
2000 & 435 & 344,886 & 178,796 \\
2001 & 442 & 355,121 & 204,383 \\
2002 & 509 & 331,692 & 335,326 \\
2003 & 524 & 360,134 & 313,002 \\
2004 & 572 & 399,937 & 316,834 \\
\hline
\end{tabular}

Working together in an effort to mobilize the membership behind the project, the building committee presented the plan to the church and a vote was taken. Evidence of growth and the possibilities for future growth were clearly evident. Although all the money was not in hand, the committee recommended that the church advance in faith. This bold step was taken for a number of reasons. First of all, White's counsel supports such a move. She writes: "The supply in their hand may seem to fall short of the need to be filled; but in the hands of the Lord it will prove more than sufficient. . . . A greater faith in the onward progress of His cause in the Earth, this is the greatest need of the 
church today." Elsewhere, she advises: "We all need to be wide awake, that, as the way opens, we may advance the work in the large cities. We are far behind in following the instructions to enter these cities and erect memorials for God. We are to continue working until a church is organized, and a humble house of worship is built." ${ }^{22}$ She also reminds us that as a result of following God's instructions, help will come from people who are not of the faith. "I am greatly encouraged to believe that many persons not of our faith will help considerably by their means. . . In many places, especially in the great cities of America, help will be given by such persons." 3

Furthermore, White counsels that it is sometimes appropriate to take out loans. "It is right to borrow money to carry forward a work that we know God desires to have accomplished. We should not wait in inconvenience, and make the work harder, because we do not wish to borrow money." She moderates this with caution that we do not take out loans needlessly, however, advising that we move forward by faith and work in a very wise way. In Counsels on Stewardship, she explains:

Let us not give the impression that we find it too great an expense to provide for the reception of the heavenly guest. In laying plans for building, we need the wisdom of God. We should not needlessly incur debt, but I would say that in every case, all the money required to complete a building need not be in hand before the work is begun. We must often move forward by faith, working as expeditiously as possible. It is through a lack of faith that we fail of receiving the fulfilment of God's promises.

${ }^{1}$ White, Prophets and Kings, 243.

${ }^{2}$ White, Evangelism, 379.

${ }^{3}$ Ibid., 379.

${ }^{4}$ White, Counsels on Stewardship, 278. 
We must work and pray and believe. We are to move forward steadily and earnestly, trusting in the lord, and saying, "We will not fail nor become discouraged."'

In addition to consulting the wisdom of White, the finance committee had looked at the local financial trends of the church over several years before coming to its decision. It found that the growing trend was very positive. See Table 9.

\section{TABLE 9}

CHURCH BUDGET TREND (1998-2003)

\begin{tabular}{lc}
\hline Year & Church Budget Amount in Canadian \$ \\
\hline 1998 & 161,634 \\
1999 & 144,132 \\
2000 & 215,389 \\
2001 & 204,383 \\
2002 & 335,482 \\
2003 & 313,002 \\
\hline
\end{tabular}

The financial strategy entailed determining the cost of the project as well as the sources of funding, all before the work began. Jesus made reference to the importance of this, talking about the need to have enough money to complete a project before it begins (Luke 14:28). There were five different ways in which it was determined that we would gather the necessary funds for the construction project: (1) through systematic benevolence, and from (2) individual pledges from members, (3) loans from the revolving fund, (4) bank financing, and (5) funds from non-members.

In order to encourage members to be engaged in systematic benevolence a plan called Plan 10/10 was launched. As discussed in chapter 3, systematic benevolence entails members giving a specific amount to the church on a weekly or monthly basis.

${ }^{1}$ Ibid., 280. 
This means intentional giving by the members without the need for constant appeals or prompting. Under Plan 10/10, members were asked to return a second tithe each month for the work of building the sanctuary. This second tithe was to be put into the church budget so that there would be adequate funds to do the Lord's work. This idea was very successful. While not all church members were willing to be a part of this plan, those who did have already been blessed. Many are still supporting the church through the plan.

For members who desired to give more or give less than the 10 percent prescribed by the systematic benevolence plan, a plan was put in place to accept personal pledges from members. Pledges are commitments to give a specific amount at a certain time, apart from regular planned giving. As explained in chapter 2, this approach stems back to the days of Moses. Before beginning work on the construction of the Hebrew Sanctuary, Moses had asked the people to bring in offerings, and the people ended up giving more than was needed to complete the work. Moses even had to stop them from giving (Exod $36: 5,6)$. In the first century $\mathrm{AD}$, the early Christians made pledges to the work of the gospel by selling lands and other possessions. They gave the money to the Apostles (Acts $4: 37)$.

As a result of personal pledges made to the Downsview Church's building fund, $\$ 75,000$ was received from members during 2000 . This offering was above and beyond the regular giving. It amounted to a pledge of $\$ 1$ per year for two millenniums, all toward the work of God. Those who were not able to give a lump sum of $\$ 2000$, or 10 percent, gave 5 percent or even less. The strategy was to encourage everyone to participate in the process in whatever way they could. 
A third source of funds for the project came through the Revolving Fund. This is a fund that is administered by the Seventh-day Adventist Church in Canada. Money is lent to organizations within the Adventist Church at low interest rates. To access the funds, the church had to submit a request to borrow an approved amount for a period of time not to exceed twelve years. The Revolving Fund is set up to finance an amount equal to two times a church's previous year's tithe income. We received $\$ 690,000$ from this fund. The interest on the loan was at 3.25 percent, calculated based on the prime lending rate at the commercial banks plus 1 percent.

The fourth source of financing for the project came from a commercial bank loan. Commercial banks are willing to lend funds for building projects with security from the organization. This type of loan was necessary because the revolving fund loan was not sufficient to finish the project. We had to first get the approval of the Conference before turning to a commercial bank to finance a loan. Approval was granted.' The amount of money that was borrowed in this way $\$ 890,000$. This was at an interest rate of 5.5 percent and over a period of twelve years.

The fifth, and final, way that the church managed to get the funds it needed for the project was through non-member donations. Letters were given to members, asking them to contact people who might be interested in supporting the church. Strangers, tradesmen, friends of church members, and people who might be willing to make donations were contacted. Again, this had a basis in Scripture. Nehemiah asked the King Artaxerxes to give him a letter to request timber from Asaph, to rebuild the walls of Jerusalem (Neh 2:

\footnotetext{
${ }^{1}$ Ontario Conference of Seventh-day Adventists (Oshawa, Ontario), Minutes of Board of Directors, 38-2001, March 18, 2001.
} 
$8,9)$. In a similar manner, church members were asked to request donations from people who were not from the church. The amount received in this way amounted to approximately $\$ 10,000$.

The Experts Involved in the Building Process

An important part of any building strategy is selecting the right people to work on the project. In selecting people to work on the construction of the Hebrew sanctuary, Moses chose those with the best experience and skills to do the work. They were men and women of wisdom, who were skilled in all manner of work such as stone cutting, and engraving of gold, silver, and brass (Exod 35:30-35). In our building project, we exercised great care in choosing the right people for the right jobs. The committees chose people with a combination of commitment and personal skills. They were people with expertise who could provide information and insight in areas such as construction, architecture, interior design, carpentry, and plumbing. Ralph T. Mattson offers useful advice on the selection of the appropriate people. "Appropriate selection requires the identification of those gifts that will actually match what is in the job description. Giving authority to a person who does not have the gift to pull off what is needed assures mediocrity. Giving authority to the person with the appropriate gifts and experience can only end up with excellence."'

The committees made an effort to select people not only for their special skills and expertise but also for their demonstrated personal commitment to the church. The primary people chosen to work on the project needed to be (1) people who had

\footnotetext{
${ }^{1}$ Ralph T. Mattson, Visions of Grandeur, Leadership That Creates Positive Change (Chicago: Moody Press, 1994), 157.
} 
experience and access to information needed by the committees; (2) the kind of persons who could benefit by working with people who had more experience; (3) people who could develop a greater sense of commitment to the church by working on the committee; and (4) people who had the best access to the resources needed to do the job. Others who wished to work on the project, but who had no specific skills that were needed, were asked to make financial contributions or to work with the skilled people as volunteer helpers.

The building committee invited each person being considered for a position to an interview, asking him or her questions about personal experience in the relevant trade, the number of years in business, and for a sample of work done in the recent past. Once the interviews were completed, the information was checked and analyzed by committee members to confirm discussions at the interview. Once a name was chosen, the decision was taken to the church for approval. The most important positions needing to be filled were the position of architect, project manager, and deputy project manager.

Great care was taken in selecting just the right architect for the job. The architect is the designer of the project. This person has to be able to determine what the church wants and put it in the blueprint. As the church considers the design, it is a good idea to have a preliminary estimate to be sure that the church is able to afford the project as designed. Jules Donald Jernigan advises that the architect be someone of "the same denomination, or a similar one, who is already familiar with the special functional requirements of the church regarding worship and Christian education."' The building

\footnotetext{
${ }^{1}$ Jules Donald Jernigan, Quest for the Rainbow: Basic Guidelines for Building Churches (Grand Rapids, MI: Baker's Book House, 1975), 12-13.
} 
committee looked for architects who had experience in designing churches. The committee wanted to see some of the churches that were built recently by the architect.

On the prospective list were four names, all very experienced people who had worked in the business for more than ten years and who had excellent track records. Two of the four had worked for the Seventh-day Adventist Church before. One had no past history of preparing plans for churches. The fourth person specialized in designing churches. The architect that was selected was done so on the basis of her specific interest in designing churches as a ministry for God. She wanted the physical structure to make a statement about Christian faith. She was not only capable of doing the design for the project, but she was capable of putting the spiritual imprint of the church in the design. After looking at recently built structures she had designed and talking to their owners regarding her work, and after reviewing her credentials, the building committee recommended to the church that we retain the services of this person.

The architect we chose for this project is someone who believes that her services for God are more important than just making money. Although she had to charge for her services, it was clear that she was not doing her work primarily for making money. Her clear expression of faith and humility in working for God gave the members of the building committee the confidence that they would be working with someone who understood the needs of the church and could put that need into a design. We were not to be disappointed. In the end, she gave additional time and information to the church without asking for extra compensation.

The next most important step was selecting the project manager. David I. Cleland says of project management that it is "a series of activities embodied in a process of 
getting things done on a project by working with members of the project team and with other people in order to reach the project schedule, cost, and technical performance objectives." Donald Penner describes the project manager as someone with "the responsibility for the what, when, why, and funding of project requirements as well as for the who, how, and where of project execution."2 The role of a project manager is that of a decision maker. He sets realistic goals for the project to be completed on schedule. J. H. Hanna describes the project manager as one who has "decisions made on the project quickly enough to meet its needs, and benefiting the project as a whole - not just a portion." ${ }^{3}$ He sets the time table for the completion of each task and informs the church and the contractors of the consequences of delays on the job.

Our project manager worked closely with the church-building committee to achieve the desired goals of the church. Hanna cautions that the "project manager should have the same authority as the 'Boss' for his project, and only his project." James A. Bent and Albert Thumann list seven skills that a project manager should have: (1) good decision making; (2) competent planning; (3) creative organizing; (4) realistic delegation;

'David I. Cleland, Project Management Strategic Design and Implementation (Boston, MA: McGraw Hill, 1994), 39.

${ }^{2}$ Donald Penner, The Project Manager's Survival Guide: The Handbook for RealWorld Project Management (Columbus, OH: Battelle Press, 1994), 9.

${ }^{3}$ J. H. Hanna, What Is a Good Project Manager?, quoted in Arthur E. Kerridge and Charles H. Vervalin, Engineering and Construction Project Management (Houston, TX: Gulf Publishing Company, 1986), 74.

${ }^{4}$ Ibid., 74. 
(5) follow up on delegation; (6) effective communication; and (7) adequate common sense. ${ }^{1}$ Our project manager had all of these skills.

This task of project management entails a strategy for planning and control of the building project. The project manager manages various teams of workers and guides them in making wise decisions so that the project will successfully be completed within the budget. The project manager makes sure that the project of constructing a new place of worship happens according to plan. David Burstein and Frank Stasiowski describe the responsibilities of the project manager as including "accomplishing the project objectives in spite of problems." The project manager must know "when to take charge, he serves the client, he meets schedules, [and] he makes a profit on every job."

The project manager must perform several different activities simultaneously. He works with the different trades to accomplish different tasks. Milton D. Rosenau, Jr., defines the role of the project manager as entailing the performance of five different activities.

1. Defining-defining the project's goals.

2. Planning-planning how you and your team will satisfy the Triple Constraint (goal) of performance specification, time schedule, and money budget. (The plan depends on the mix of human and physical resources to be used.)

3. Leading-providing managerial guidance to human resources, subordinates, and others (including subcontractors) that will result in their doing effective, timely work.

4. Monitoring-measuring or controlling the project work to find out how progress differs from plan in time to initiate corrective action (this often leads to re-planning,

\footnotetext{
'James A. Bent and Albert Thumann, Project Management for Engineering and Construction (Lilburn, GA: Fairmont Press, 1994), 3.

${ }^{2}$ David Burstein and Frank Stasiowski, Project Management for the Design Professional (New York: Whitney Library Design, 1991), 15.
} 
which may force a goal [definition] change, with a consequent need to change resources).

5. Completing-making sure that the job that is finally done conforms to the current definition of what was to be done and wrapping up all the loose ends, such as documentation.'

The church committee chose the project manager they did because he clearly understood the work of construction. In the end, this was proven to be a good decision. Because of his experience, he helped the church to exercise control over the cost of the project, the quality of the material that went into the project, and the time that the project took to be completed. The goal of project management is to work with the church to accomplish its goals to a greater satisfaction.

During the construction process, our project manager conducted biweekly site meetings with members of the building committee and the sub-contractors. The purpose of the meetings was to review the tasks of the workers and receive updates on the progress of the work. At these meetings, recommendations or changes were were made to the plan when they were necessary. Our project manager worked closely with the church to control the cost of the project and the quality of material. He monitored the timing of the project from start to finish. He organized and assigned various tasks to all the people who worked on the project, including the church volunteers.

An alternative to project management would have been something called the "turn-key" strategy. In a turn-key-type project, a contract is signed with a contractor for a lump sum. In this case, the contractor becomes the sole decision maker until the work is completed. Changes to the job could be made, but this would increase the cost. With a

'Milton D. Rosenau, Jr., Project Management for Engineers (New York: Van Nostrand Reinhold Company, 1984), 7. 
turn-key strategy, a church would have little or no control over inflationary cost, product quality, and timing. The story of a Seventh-day Adventist Church in Alberta, Canada, which was built by turn-key process may provide a useful illustration of what can happen when the turn-key strategy is adopted. The building ended up being completed at a cost that was double the contracted price. When the church refused to pay, the matter resulted in litigation. A project management strategy prevents such an embarrassing situation from arising because it prevents surprises.

A close second in importance to the project manager is the deputy project manager. His job is to assist in the management of the project. In our project, the deputy project manager was a church volunteer who took the time off his personal work to assist in the construction of God's dwelling place. He worked along with the project manager to observe and to carry our miscellaneous tasks as he was directed. He was fully aware of all that happened with the project and was able to take over the operation in the event the project manager was sick or needed to be away.

Finally, it is important for a church to have a strategy for accepting bids on the project. One of the duties of the project manager is to put the work out to tenders. The purpose of this is to give every contractor equal and fair opportunity to prepare an estimate and use it to develop a bid. A complete set of drawings was given to each interested contractor with a deadline to submit an offer for the job. The successful bidder entered into a contract with the church and the project manager.

\section{Summary}

There are four primary lessons to be learned from this chapter. The first lesson is to plan before you build. In a review of current literature on the subject of management, I 
have found that the best strategy to get a job done begins with a plan. The important thing is to put into place a system that will get the job done in the most cost effective manner. In building the new Downsview Seventh-day Adventist Church, the plan was to organize the members of the church to work in various committees to transform the vision of the church into action. It took many hours of planning to achieve the most advantageous results. Building a place of worship required the unity of all the members, particularly those with related skills. The more people who were involved in the responsibility to work for the church, the less likely it was for one person to do the work alone. That strategy worked in motivating the members to give of their time and money for the mission of the church.

The second lesson is to act upon your plan with faith. The project management strategy for building a church taught some valuable lessons about good planning. It got members involved in the process of carrying out the mission and goals of the church. Through this process, goals and objectives were more clearly defined. Each task was accomplished according to specific guidelines. Weekly and monthly meetings created an atmosphere of accountability. As the work progressed, church members saw how funds were being spent and the quality of the materials they received for the money. It required sacrifice, commitment, and dedication on the part of spirit-filled men and women to put the vision of the church into day-to-day action. Although there were many challenges, the project was completed according to plan. This strategy worked well to the advantage of the church.

The third lesson is to carefully take control of spending with a clear financial plan. The church borrowed money to finance the project. Considering that the 
construction business is very sensitive to inflationary pressures, it was very important for the congregation to take control of its spending. Although the trend in the construction business is to increase profit, the project management strategy gave the church control and flexibility over the project from the start to finish. The expert advice of a committed architect and a project manager were key to our success. This is a process worth considering by those who would build a new place of worship.

Finally, as a church we should appeal to people in the church and outside the church for help. People will give to a project when they understand the common cause. 


\section{CHAPTER 5}

\section{THE BUILDING DESIGN, PROCESS, AND COMPONENTS}

Writing about the physical place of worship, Thomas Barrie suggests that a meaningful church building "needs to possess an environmental identity that gives its inhabitants a sense of belonging and connection." Fred A. Stitt, an expert in designing church space, describes a building design as something that helps arrange "spaces in a sensible relationship to one another and to the world outside." Before work began on the construction of the Downsview Seventh-day Adventist Church building, a design was prepared that gave detailed information concerning the project. It explained what was to be done and how things were to be done, all in language easily understood by contractors. It gave the description of the internal and external features of the building and how it would look in comparison to other buildings in the area.

David D. Red describes a building design as "a mental process that produces a product that solves a functional problem."3 Our design gave the outline of where the

'Thomas Barrie, Spiritual Path, Sacred Place: Myth, Ritual, and Meaning in Architecture (Boston, MA: Shambhala, 1996), 52.

${ }^{2}$ Fred A. Stitt, Designing Building that Works (New York: McGraw-Hill Book Company, 1985), 52.

${ }^{3}$ David D. Red, Rational Design (New York: Vantage Press, 1990), 1. 
structure would be located on the lot. It showed the elevation of the building along with the contour lines. It showed the entire outline of the interior layout of the building, the floor space, the basement, and the footings. It clearly identified the place for worship, the fellowship hall, space for social gatherings, storage space, classroom space, and other details. The design for the church consisted of several sets of drawings. Each set detailed instructions of how the work was to be carried out. The drawings included the site plan, the heating and ventilation drawings, the plumbing drawings, the electrical drawings, the sectional drawings, and the soil impact report. The purpose of this chapter is to give a description of the entire project from design to completion. This will include a narrative of the building process.

\section{Overview of the Building Design \\ Theological Considerations}

Before work began on the design, theological considerations were taken into account (see chapter 2). The most important theological consideration was that designing a place for worship is a sacred trust from God to mankind, as we see from studying the Scriptures. A careful study of the building of the Hebrew sanctuary showed that it was well planned. God called Moses and gave him the pattern for erecting the earthly sanctuary (Exod 25:8, 9, 40). It was to be the dwelling place for God, a sacred place. Moses erected the building according to the design that God gave him in the mount, and he carefully followed the divine blueprints until the work was completed (Exod 39:4243).

Another biblical consideration that was important to this project came from the experiences of David in preparation for building the temple. David made careful plans for 
the building of the temple before he gave the plan to Solomon (1 Chr 28:11-13). The design gave a description of all the rooms, even including their furnishings. It included a specific description of the places for atonement, the treasury, the priests and Levites, and storage. David then gave his son Solomon all the instructions (1 $\mathrm{Chr} 28: 19$ ). The place of worship was properly laid out with each place dedicated for a particular function.

White counsels that we should erect a building that is plain, neat, and perfect in design. "We have no command from God to erect a building which will compare for richness and splendour with the temple. But we are to build a humble house of worship, plain and simple, neat and perfect in its design." With respect to architectural design, she continues that churches "need not all be built in precisely the same style. Different styles of building may be appropriate to different locations."2 The important point is that while physical buildings may be different in design, the one outstanding characteristic common to all is that each building should represent the perfection that God requires of His people. The one important consideration is to have the necessary conveniences to facilitate the mission of the church. At the Downsview Church, we followed several steps to help us determine the right design to meet the needs of the congregation. We gave careful consideration to the idea of the function of the church. The committees considered the church building to be a place for preaching, teaching, and nurturing believers in their faith.

\footnotetext{
${ }^{1}$ White, Evangelism, 377.

${ }^{2}$ Ibid., 379.
} 


\section{Designing Interior and External Space}

In preparation for the building design, the building committee considered how the space in the new building could be appropriately used. Some of the questions they asked included: Would the space be adequate for all the various functions of the church? What form would the building take? How would it serve the functions of the church? Would the design allow for future additions to the structure? Would the building be flexible in the use of space?

Making a decision regarding this last question about flexible space was of key importance to the church. Focusing on flexible space is a popular trend in church building today, and the church needed to decide if it would or would not go along with this trend. Belknap argues that “today's stewardship requires that flexible space become a high priority in the construction of church buildings."' The Downsview Church building committee, upon careful consideration of the matter, decided against the idea of flexible space, however. They decided against designing a structure that could be used for multiple purposes during the week or on weekends. This decision was made after having visited several newly built churches in the Toronto area, churches that had been built for multiple purposes. One building I visited along with the building committee was a Salvation Army Church in its final stage of construction. This large building had all the appearances of a church from the outside, but inside told a different story. The space on the inside was constructed for multiple purposes. It could be used as a gymnasium, a day care, banquet hall, a place to serve food to the homeless, and, of course, a place for

\footnotetext{
${ }^{1}$ Belknap, 53.
} 
weekly worship services. Although the concept had its attractive qualities, overall, the committee was not impressed with the results.

The question of primary importance in the design of our building was to focus on the specific function of the building. What is the function of a Seventh-day Adventist church? From the very beginning, the church was designed to preach the gospel. A Seventh-day Adventist church, then, functions as a training center for evangelism. As White counsels, "In our churches let companies be formed for service. In the Lord's work there are to be no idlers. Let different ones unite in labor as fishers of men."' It is a place to organize the members to work for God. It is the center of spiritual life for the members. The church is a sacred place where God meets with his people. White counsels that there should be a distinct separation of the common and the spiritual in worship space: "There should be a sacred spot, like the sanctuary of old, where God is to meet with His people. The place should not be used as a lunch room or as a business room, but simply for the worship of God."2 And elsewhere she explains:

There is a distinction to be made between the sacred and the common, and we are accounted to God if we place human wisdom at the head as essential for education. ... The House erected for the worship of God should be cherished with sacred reverence by parents and by children. ... Its sacredness should not be confused or mingled with the common everyday feeling or business life ${ }^{3}$

Elsewhere, White writes, "From the sacredness which was attached to the early sanctuary, Christians may learn how they should regard the place where the Lord meets

${ }^{1}$ White, Evangelism, 110.

${ }^{2}$ Ellen G. White, “Building a House for God,” Manuscript 23, 1886, Ellen G. White Research Center, Andrews University, Berrien Springs, MI.

${ }^{3}$ Ellen G. White to Brethren Greggs and Howe, 23 August 1898, letter G 65, 1898, Ellen G. White Research Center, Andrews University, Berrien Springs, MI. 
with His people."' It is clear that White connects the sacredness of the Hebrew Sanctuary to our present place of worship. Thus, the function of the church building is to reflect the same purpose and mission of the ancient sanctuary. The church building is a place where God meets with his people for worship and fellowship.

One of the most important tasks was preparing the internal design of our church. The interior design focuses on the floor plan and the designated space for the various liturgical functions and requirements of the congregation. The design of the worship space itself is the most important decision to make in this respect. The worship space is the area designated for the gathering of people to worship. Care must be taken in designing space for worship. It is the place where people come to hear the word of God. James F. White argues that this space should be arranged so that the preacher and the people can see each other. "The location of the pulpit depends on the arrangement of the congregational space and choir space. The preacher needs to be able to see everyone to whom he or she is preaching, including the choir members." ${ }^{\text {2 }}$ We thus had to decide on the location of the pulpit, whether we wanted it in the center for preaching the word of God or on the side. We had to decide if we wanted a balcony and how we wanted to handle the baptistery and seating for the choir.

We further had to decide whether we wanted pews or chairs. Although pews would be more expensive than chairs, we decided for this option. We decided as a

${ }^{1}$ White, Testimonies, 5:491.

${ }^{2}$ James F. White and Susan J. White, Church Architecture (Akron, OH: OSL Publications, 1998), 28. 
congregation that this indicated more of a dedication of the worship space to worship services rather than leaving open a flexible use of floor space.

The church performs several ordinances such as communion, baptisms, weddings, and funerals. In designing the area for worship, appropriate consideration was given in outlining the space for each ordinance. With respect to designing the space for the Lord's Supper, White states the following; "Visibility, proximity, and accessibility are prime concerns in ordering space for the sacramental worship. The entire community needs to be able to see the actions of those who preside."'

Concerning baptismal space, White points out two major concerns that are related to design. "In terms of architecture, there are really only two essential components for the rites of Christian initiation: a container for water and a place to put that container." The Bible tells us that people must be baptized in much water (John 3:22, 23). John baptized in Aenon, because there was much water. Hence, we decided on the design of a baptismal pool that would hold sufficient water for people to enter into and be baptized. When the plan was completed, the baptistery was located in the center of the platform facing the congregation. The congregation would have full view of the baptismal services.

Aside from the main worship space, we had to decide on whether we wanted to build a social hall and how we would arrange classrooms for children's Sabbath school classes. Every space in the building is related to every other and all had to be considered in the design. The architect worked with us, analyzing what we had decided was the function of the church, helping us come up with a plan for the internal design space that

\footnotetext{
${ }^{1}$ Ibid., 38.

${ }^{2}$ Ibid., 55 .
} 
would serve the mission of the church and the needs of its worshippers. Focusing on design also entailed considering art.

Liturgical art is important to a church. James F. White writes that the main purpose of liturgical art is to make us aware that we are in the presence of God. "Part of the purpose of liturgical art in the church is to underline the seriousness of what we are about when we gather for worship. This is not a casual assembly; this is the people of God meeting with God."

In designing our new church, another important consideration was the external design of the building. This describes how the building looks in relation to other structures in the area. It is concerned with the outer facade, the style of the building, and the material that will be used for the building. The focus of the external design should be centered on what goes on inside the building, rather than on the outside. This new design should respond to the mission of the church. The aesthetic appearance should give the onlookers a positive visual effect and a feeling of welcome, while at the same time will not invite intruders. It is important that the exterior facade harmonize with other buildings in the surrounding environment. As in all things, Ellen White counsels against the outward show and the large outlay of money. "An unnecessary expedition of money means that there will be less to invest in the work of God."2

${ }^{1}$ James F. White, Church Architecture, Building and Renovating for Christian Worship (Akron, OH: OSL Publications, 1998), 126.

${ }^{2}$ Ellen G. White, "Work in Christ's Line," 8. 
Deciding on Structure and Location

The location of the building on the site was another issue of great importance to us at the Downsview Church. Some members wanted the new structure to be attached to the old building, while the old building would be used as a social hall and part of the new facility. Other members wanted the new structure to be close to the front line of the property and close to the street. These people argued that locating the building near the front line of the property would leave adequate space on the site to plan for events such as tent evangelistic meetings as well as leaving room for future development. It was difficult to design the structure without provoking considerable controversy over the location of the new facility. Locating the building on the site was a great concern to many people. The concern was based on the fact that once a spot was identified it would be difficult to change that location later. Members would become discouraged over where the building was located on the property. Writing about the history of church construction, Vicki Bennett touches on the importance of the building's location on the site:

Church architecture continued to be seen as an indicator of where the center of activity was to be. The location of a church building continued to have an important effect on defining where the center of newly settled communities would be. For this reason, great importance was still attached to the church site, even before the building itself begun. Once chosen, it was difficult to change the site without provoking considerable controversy. ${ }^{\prime}$

After much consultation with the architect and church members, we decided to locate the new facility towards the front of the property line, leaving the old building to stand alone. We decided that building a new free-standing structure would be a sign of

\footnotetext{
${ }^{1}$ Vicki Bennett, Sacred Space and Structural Style (Ottawa: University of Ottawa Press, 1997), 91.
} 
giving the best to God. We thought it would be a sign to the church community that we should not be content with taking old structures that had been used for secular purposes and then converting them to sacred uses.

Once the decision was made about location on the property, it was time for us to prepare the site plan drawings. The purpose of these was to locate all important points on the property. The site plan identified the spot for the new building, the property lines, the existing buildings, drainage, and any other utilities that were on the lot. The site plan also showed the elevation and topological features of the site. The topographic features showed the existing and final elevation by means of contour lines. It also showed the soil conditions at various elevations on the site. The site plan drawings showed the elevation and the view of each side of the building along with the external appearance of the structure, the floor, the finish grades, and ceiling heights.

Another important decision we had to make was with respect to the material for the building itself. What kind of material was to go into the structure? Would the building be made of concrete, bricks, wood, or stones? Vicki Bennett points out that the majority of older church buildings in Canada were constructed out of wood.

Bricks were not used in the construction of earlier churches primarily because they were not readily available. Stone was widely considered to create a sense of endurance and permanence and was usually the preferred building material; however, stone churches were expensive. In their humblest forms, many of these early churches had little if any external arrangements or embellishments.'

In Canada today, bricks and steel are more readily available than wood. To build our church, we decided on using a combination of bricks, stone, and steel. We thought this would give a sense of endurance and permanence. For the foundation walls, we chose

$$
{ }^{1} \text { Ibid., } 43 .
$$


concrete, for the frame, steel, for the side walls, bricks, and for the front wall, bricks, and ivory stones.

Once we knew what materials we would use for the building, the next step was to prepare the structural drawings. These drawings showed the steel frame structure of the building. It described the size and positions of all columns, the beams, girders, and trusses. It gave the detail of how the steel and lumber were to be used in the construction of the building. All the structural steel and reinforcing steel was cut to size in fabricating plants before they were brought to the site for assembling. Every piece of steel that appeared on the structural drawings was fitted according to the specification on the plan. We also had mechanical drawings that were used by the plumbers and heating and ventilating workers. These drawings showed the size and location of all pipes, valves, pumps, vents, and other information needed by the various trades.

\section{Narration of the Building Process}

The Downsview Seventh-day Adventist Church building project was completed in June 2003. After more than twenty years in the planning, the congregation now has a new sanctuary for a permanent place of worship. The prayer and thanksgiving service to mark the official opening was a very joyful occasion. The last nine years in the history of the building of this church had borne witness to the blessings of God in good planning, spiritual leadership, and sound financial management.

\section{Steps Leading to Beginning of Construction}

On the first Sabbath of my new assignment, in September 1994, the senior elders of the church were divided over plans for the location of the church building. I witnessed the dispute, which was caused by several failures of the building committee to close an 
offer of purchase on a church site. This was one of several failed attempts to purchase a place for worship. The church was unable to access the funds necessary to close the purchase because most of the church funds were invested in a residential property. To make matters worse, this residential property (which was supposed to be an investment for the church) was declining in value. Rent had not been collected for three to six months because very costly repairs were needed on the property. Members of the building committee did not have the time to do the repairs, and the plans of the church were at a stand-still. Anger, frustration, and accusations were all expressed in my first business meeting with the church members. I found it a real challenge to assume responsibility of a congregation so bitterly divided. I knew that I must rely on the Lord to give me an extra supply of faith, courage, and wisdom to guide his people.

My first task was to conduct a needs assessment. I wanted the church to have a clear vision so that together we could focus on the most important matter at hand. Through a series of meetings with the elders, departmental leaders, and the members in general business meetings, certain priorities were established. The meetings provided a clearing house of ideas for the church. I wanted to work with the ideas and the objectives established by the church to restore unity in the body. As a result of all this, I was convinced that the members wanted a permanent place for worship. They had been moving from place to place for too long. In seventeen years, the congregation had moved five times. They had had six pastors, serving an average of less than three years each. They had experienced too many inconveniences in worship services and in their outreach ministries. The most important need facing the congregation was to find an appropriate place for worship. 
We thus decided to put together a plan for building a new church structure. The first step was putting together a two-year plan. The goal of this plan was to acquire a place of worship within two years (January 1, 1995, to December 31, 1996). The plan called for all the members to unite in a systematic plan and contribute $\$ 150,000$ to the Church building in 1995 and another $\$ 150,000$ in 1996 . As a result of this plan, forty-one members pledged a total of $\$ 110,198$. The rest of the money came in from other members and outside contributors to the church. When we decided to form a building committee, I took this to be the beginning of a new direction for the church. The members wanted a new vision. The church's new pastor and new committee signaled the creation of that new beginning.

The new building committee began its work by conducting its own needs assessment for the church. It conducted several meetings to determine the direction of the church, which resulted in a number of recommendations.

The first recommendation was to sell the residential property that the church had as an investment. This would give the church immediate access to the funds when a property came up for sale. The second recommendation was that the proceeds from the sale be placed in a term deposit at the bank. At the time of the sale, the property value had declined by more than $\$ 40,000$ in less than a year. That was due to an economic recession and the above-stated lack of repairs on the property. The third recommendation was to acquire a permanent church home by the beginning of 1997 . That was a new direction with specific goals and objectives for the church.'

\footnotetext{
${ }^{1}$ Recommendations of the Building Committee, Prepared October 19, 1994.
} 
The plan inspired new zeal and determination in the believers. Within six months, a site was found for the church. On May 1, 1995, with the full cooperation of members, church leaders, and the pastor, the church purchased a two-acre lot with a small 5,000 square foot industrial building at a prime location in the city. Although the building was not designed for a place of worship, the members were willing to renovate and occupy it until a more suitable place was constructed. This building was renovated to form the first place of worship for the congregation. The first service was conducted in the building on the first Sabbath of January 1996. The plan had been accomplished one year ahead of schedule. In only one year, the church had a place of worship.

Based on the success of the two-year plan, the church extended the plan to another three years. The church wanted to continue the new spirit of cooperation and spiritual revival among the members. The three-year plan was a continuation of the existing plan with some variation. The plan added six other objectives: (1) spiritual growth among the members of the congregation; (2) plans for evangelism and soul winning; (3) the building of a new sanctuary; (4) training and equipping leaders; (5) mobilization of the youth for greater service; and (6) every member to become a faithful steward. At the end of the three-year period, the plan was to be evaluated. Although all the objectives were not accomplished, this plan created a greater sense of unity of purpose in the church.

The three-year plan included a call for spiritual leadership. When I took over as pastor of the church in 1994 , I found that most leaders would be present only for Sabbath services. During the week, they were busy with personal matters. I felt that the leaders did not understand the commitment required for service. While there are other qualities 
necessary for a spiritual project, to be filled with the spirit of God is absolutely indispensable. When undertaking such a project, a church needs leaders who can translate the vision of the church into action, men and women who lead by their action and examples. It needs leaders who understand the principles of unselfish service and leaders who are concerned with the welfare of others, not only their own comfort and prestige. It needs leaders with the ability to communicate well and listen to others, who know the art of delegation. It needs leaders who know their own limitations and how to get things done by engaging the services of others.

In order to help create the right leadership for the church, I conducted a training program. In the training program, the duties and responsibilities of the members were outlined. The leaders were trained to train others. We also began a new approach to the election of leaders. Instead of basing decisions on position or ambition, we began basing them on spiritual gifts. As a result, we ended up replacing many who had for years been leading. We elected new leaders who had a good sense of commitment and dedication to the work of God. As was to be expected, there was some opposition to the changes. To counter this, I preached sermons outlining the ministry of spiritual gifts. I conducted training seminars on leadership and evaluated the leaders each year. This was, of course, not an easy task as some leaders were naturally very resistant to change.

Another important task was financial planning for the project. The church had lost $\$ 40,000$ from the sale of its investment property. The property had been purchased with the hope for increasing funding for church building, but the sale, made four years after it was purchased, ended up losing money for the church. Investing money in real estate with the aim of increasing profit is a risky way to raise funds for church building. Despite 
the loss, within the first six months of my assignment, the church purchased the first property for building a place of worship. This was possible partially because we had formulated a new vision on financing.

The new vision called for every member to contribute to the building project. I encouraged the members to follow biblical models for fundraising, making every effort to discourage members from resorting to worldly practices such as concerts, banquets, bake sales, yard sales, and other means of fundraising. I emphasized sacrificial giving and systematic benevolence. I preached sermons and used illustrations from the writings of Ellen G. White to support the new approach to fundraising. The response to this new vision was very successful. A new spirit of sacrifice took hold of church members. We received more funds in the first year of this new plan than had been received in the previous year. In 1995 , the total offering contributed to the Church was $\$ 300,000$; in 1994 , the amount had been $\$ 250,000$. Church members were inspired, and the response was tremendous. The money came into the treasury because the members had come to understand more clearly the principles of sacrificial giving. In response, many made pledges while others gave a second tithe.

When the time came to build the new sanctuary, the church needed to raise $\$ 2,000,000$. This was a venture in faith. With only $\$ 500,000$ in cash and pledges, the church needed to raise the extra $\$ 1,500,000$. To obtain the funding necessary to complete the project, we sought help from the local Seventh-day Adventist Church Conference in Canada and the North American Division of Seventh-day Adventists. We borrowed money from the Canadian Seventh-day Adventist Church's Revolving Fund in the amount of two times the annual tithe from our church, which came to $\$ 690,000$. (When 
this amount was combined with a loan we had left over from a previous project, the amount we owed to this fund came to a total of $\$ 710,000$.) To qualify for this funding, the church had to have 50 percent of the total cost of the project in hand. We also received approval to borrow money from a lending institution to finance the new building. From the commercial bank, we borrowed $\$ 890,000$. With the volunteer help of the members, the project was completed within the budget.

When the church first purchased the two-acre property for the building of the new sanctuary, we had no idea that it would trigger conflict in the church. The first conflict stemmed from a battle over how to come up with the money to build the new structure. One member of the congregation had a plan for himself. He wanted the church to divide the property in two, sell him one part for his business, and use the proceeds from the sale to build the new building. Some members of the church were in agreement with the idea while others were opposed to it. When the building committee rejected the idea, this member came up with another proposal. He wanted the church to rent a portion of the property to him for a nominal fee. He would then use the rented portion to operate a trucking business. This was a delicate matter since this individual was an elder in the church and had served the church for many years. Some members again thought this was a good idea. But the building committee rejected his second proposal, just as they had his first. He became very upset and told members of the church that the decision showed a lack of caring for members.

Conflict was a constant throughout the building project. For instance, there was conflict on the job between individual workmen and between the contractor and the project manager. Although it was difficult at times to cope with the various problems that 
arose, these conflicts were nonetheless countered by incidents of mutual agreement, and in such cases, relationships were strengthened. Conflict can come in many shapes and forms, and we can never completely avoid it. The best way to deal with it is to identify its source. Once the source is identified, it becomes easier to find a solution. It is also important always to create a dialogue with the parties involved in the dispute and to avoid becoming a part of the problem. Gathering relevant information helps to identify the most appropriate solution.

\section{Designing the New Sanctuary}

When the time came to construct the new sanctuary, a new design was created. In the design, we gave consideration to space and the intended functions of the building. We also considered how the building would be situated in relation to the other building on the site. In the end, we decided to build the new building separate and detached from the existing building.

Our goal in the building design was to create a building that would meet the needs of the growing church. To achieve that goal, we applied an integrated design approach to the project during both the planning and construction phases. The members were actively involved in the design process, interacting closely with the architect throughout the design process. The members who would be the building occupants, and those who would be involved in the operation and maintenance, were involved in order better to create an understanding of how the two buildings would work for them once they occupied them. The fundamental challenge of that design was to understand that all the functions of the new building as well as the old building on the site were interdependent. 
At their best, church buildings connect us with our past and represent our greatest spiritual legacy for the future. They provide shelter, encourage spiritual growth, and embody our faith. But they also consume an extraordinary share of energy and material resources.

The building's design approach allowed the members of the planning committee, along with the design and construction team, to look at what the church does. We looked at all the ministries of the church. We looked at the quality of the material that would be used to construct the building. We evaluated the design for cost, functionality, future flexibility, efficiency, overall environmental impact, creativity, and how the occupants would be served.

The trend in the design policy is to create buildings that will be responsive to the needs of members as well as being economically sustainable. Toward that end, new buildings must be competently planned, functionally adequate, appropriate in form, costeffective, adaptable, durable, and contextual. The design concept not only looked at material costs, but also at services such as ministry to the handicapped, parent ministry, youth ministry, children's ministry, and outreach and fellowship. It looked at how the building and its systems could be integrated to complement existing services on its site and in the community. The fundamental challenge of the design was to understand that all the buildings and services were to be interdependent.

The new structure needed a cooperative and interactive approach to meet the design objectives. It was necessary for the people responsible for the building design to interact closely throughout the design process. The members, architects, engineers, contractors, and consultants needed to communicate and to attend the site meetings, 
which were held once every two weeks. Everyone involved in the operation, the construction, and the design of the facility fully understood the issues and concerns of all the other parties.

A meeting was called that involved the church members, appropriate designers, consultants, and the project manager to participate in a design start-up session. This session was held at the beginning of the project. The meeting encouraged an exchange of ideas and information that allowed truly integrated solutions to take form. Committee members were encouraged to discuss and ask questions regarding problems beyond their field of expertise. We held similar meetings every month until the design process was completed.

These meetings were particularly helpful in dealing with complex situations. Participants were given briefings about the issues and concerns. They learned how to cooperate with the planned solutions. Through these meetings, we accelerated the education process, verified decisions, diminished adversities, learned the nuances of organizational issues, and expedited the design process. Although we did not always produce final solutions at these meetings, we always explored the important issues.

\section{Estimating the Cost of the New Building}

To determine the cost of building the new sanctuary, we obtained three separate estimates. We then evaluated each estimate for cost of labor, cost of material, and other hidden fees. These estimates were to determine the cost of the entire project. We began with preliminary estimates, which were formulated before detail work began. Early in the planning stages, both the building committee and designers agreed to an anticipated cost of the project. These preliminary estimates during the early planning phases of a 
proposed project needed to match the needs of the church. Each estimate was put in writing, with budget constraints, in order to establish the overall scope and quality expectations. Estimates and comparisons at each stage of the project proved to be especially valuable in evaluating the feasibility of strategic alternatives. We used these in our consideration of current and projected space requirements. At this stage, a contingency was included in our preliminary estimates in order to offset unforeseen costs.

After having proceeded with a preferred course of action, we were able to employ intermediate estimates at various stages of project design development. We did this in order to maintain accountability for initial budget projections. Once we had employed the project manager, he was able to assist us with professional estimates and continually updated project estimates. He provided feedback on the budget that impacted decisions regarding major design elements. As the design progressed, and fixed costs were determined, we were able to reduce the contingency fund.

The final estimate was the contractual price after we had signed the agreement with a contractor. As the design was completed, a detailed bid estimate was prepared. At that stage, we were able to reduce the contingency fund to zero. The final estimate was the same that was agreed upon by the bidders. This then allowed us to make a comparison of the final costs for the project. In addition, having the final estimate and bids in the same format facilitated the development of a final cost for use in planning for the future.

\section{Launching the Project}

The building project began with a vision to build a suitable place of worship for the Downsview congregation. From the beginning, it was my desire to build the 
Downsview Seventh-day Adventist Church according to biblical principles of design.

The vision to build a place for worship originated in the heart of God. It was my conviction that God had commissioned me to communicate that clearly to others so that they could assist in carrying out the work to completion. There is precedence for this. God told Moses to build the sanctuary for his dwelling place (Exod 25:8, 9). God told Habakkuk to write the vision so that others could run with it (Hab 2:2). To fulfill the Divine commission, we needed to create a building that was functionally adequate, appropriate in form, and cost-effective. The structure needed to reflect the principles outlined in the Scripture regarding the Hebrew sanctuary.

The next step was to have a design that reflected the principles in the writings of Ellen G. White regarding places of worship. To achieve that, I worked closely with the designers, consultants, and members of the church, in several collaborative brainstorming sessions which were held at the beginning of the project. Each session allowed for the exchange of ideas and information that would be integrated into the design. During the meetings, we learned many lessons regarding theological considerations, the appropriate use of space, and the functions of the church building.

I felt that the work of constructing a place of worship was a sacred trust. To prepare a dwelling place for the most high God was a sacred responsibility. Therefore, every part of that structure needed to have a meaning. Our command from God was to build a structure that would teach something about God's plan of salvation.

Building a new place of worship proved to be a bold undertaking that required faith, perseverance, and hard work. One of the hardest lessons to learn was explicit trust in God. After many months of planning the project, it was scary to begin. What should 
have been a time of great inspiration to me personally was a time of fear. I began to feel like the spies who came back from viewing the land of Canaan (Num 13:31-33). I was filled with fear of failure, of conflict, of lack of funds, and of criticism. As these thoughts of fear kept flashing through my mind, I remembered the words of the Lord to Moses at the Red Sea. "Fear not, stand still and see the salvation of God" (Exod 13:13). I told myself that this was the Lord's work and we had to go forward (Exod 14:15).

\section{Building Begins}

When it was time for the actual building to begin, I felt a sense of joy mixed with a feeling of anxiety for the future. Perhaps, this was because this was my first experience in church building. On the morning of June 3, 2002, the day after the groundbreaking ceremony, I stood timidly on the site wondering if that project would ever happen. I did not want anyone to know how nervous I felt. I prayed that God would take hold of the plans and make everything work well. I knew that God would give me the courage to finish this work. As I stood on the site, the first tractor trailer came with a bulldozer tractor. In a few moments, another vehicle came with several men wearing hard hats and work boots. They were excited about the work. They were glad to be a part of a team working to build a sacred building. As I talked with them, my nervousness gradually began to disappear. Within two days, the ground was broken up. Then the removal of trees and of soil began. The landscape was now different. As the work of excavating progressed, my fears started to subside. As the work continued, I saw the earth opening up, and the trucks moving in and out of the site as the workmen carried out their various tasks. 
Just before the work began, a protective fence was erected around the work area. Signs were posted at various locations, warning of dangers. Access to the site was limited to one gate. Everyone who entered the site had to wear protective hats and boots. The construction equipment was digging up the ground and opening up the soil. Trucks were coming in to haul away the soil to the landfill sites. Each day saw new changes taking place on the site. The air was filled with dust and the smell of diesel fuel as the heavy machinery with their noisy engines were busy digging the foundation for the new structure. They were preparing the area for the new sanctuary.

A few members were willing to take time off from work to be trained so that they could help to build the church. The kind of commitment they exhibited was incredible. The assistant project manager was a committed volunteer member of the church. He had a full-time job in the computer industry. He had a young family and had to work like other volunteer members to support them. He had an admirable dedication to the church. He took time to receive training in project management because he wanted the church to save on costs. He also did the painting for the church at no cost, often working until late in the night to get the job done. He gathered a team of volunteers from the church and took them for training so they could work from a scaffold. He was always punctual, and if others were not present, he would work alone until late in the night to complete the task. I remember him once working all night and into the morning.

As the pastor of the church, I ended up having to carry more than my fair share of responsibilities. Nonetheless, although many people were expecting me to make certain decisions, I was careful not to give the impression that I was in charge. I wanted the membership to take ownership of the work. I was told on many occasions that I should let 
the people decide. Often, 1 had to sit and listen to what the people wanted and then get it done. I did many things that the members left undone. I did this to save time and extra cost to build the church. I got information from the city regarding permits. I submitted monthly progress reports to the conference. I kept in daily contact with the project manager and the site superintendent.

To avoid delays and cost over-runs, I kept a close watch of the use of material. Excess materials were returned to the suppliers for credit. I spent more than fifteen hours each day on the job. I endured the lack of physical necessities in order to complete the work as scheduled. I worked in the heat and the cold. I worked in the rain and in the snow. I worked along with the volunteers to motivate them to do the work. While doing all this, I cared for my family as well as the church family. I did not neglect my daily private devotion. In fact, it kept me spiritually alive for the task.

\section{Division of the Site}

The site service drawings described the location of various services on the site. It gave the location of the important points such as sanitary manholes, storm manholes, catch basin, proposed hydrants, and valves. Having located the existing services, the site was graded and new storm lines were put in place. The drawings gave the location of the existing pavement and showed the location of new pavement. The present elevation and proposed new elevation created a better drainage system for the property. One new driveway was created, designed to be used for both entrance and exiting of site.

Additional parking spaces for 120 cars were created. Special designed space was reserved for disabled and handicapped parking. 
The new structure was situated with a frontal setback of thirty feet from the street line, and a rear setback of twenty-five feet. The gross floor space is 20,100 square feet. All the existing asphalt was replaced with new pavement. A new sidewalk was installed on the southeast side of the new facility. As a part of environmental improvement, five trees were removed from the site creating space for fifty-four new trees that were planted in the springtime. The new trees created shade and helped to reduce pollution in the city. New landscaping enhanced the beauty of the surroundings. Parking bumpers are planned to be installed around the parking area to protect motor vehicles from destroying the green area and the trees.

\section{The Structure}

As soon as excavation work was complete, work on the structure itself began. This entire process was based on the architectural drawings that had been made before construction began. There were several types of drawings: the foundation plan, structural plan, mechanical plan, site plan, and the structural plans.

The first step after excavation was the erecting of foundation walls (based on the foundation plan). During that process, workers placed special forms around the perimeter of the new structure. The forms were made to look like a box and were reinforced with steel. Once all that work was done, the concrete was poured into the forms to create the foundation walls. Trucks brought in the concrete mixture as the men worked continuously to shape the foundation. During the pouring of the concrete, engineers performed random tests on the concrete mixture to be sure that the material was composed of the right quality for the foundation. The test results were recorded for the 
building inspector, who verified that the material met certain specific guidelines. The foundation of the church building was safe and sure.

The walls were designed to bear a weight of 5,000 pounds per square foot. There were four walls in the foundation. Each was twelve inches thick and stood four feet below the finished grade. Each of the four walls of the foundation was reinforced with steel bars for strength and durability. The walls of the foundation were designed to support each piece of slab. The wall around the ground floor was framed with six-inch metal studs. The metal frames were fastened to the foundation wall. Bricks, four inches thick, protected the outside wall with a one-inch air space between the bricks and the frame. The walls were insulated with R-12 fiberglass insulation, covered with vapor barrier. On the inside, the frame was covered with one-half-inch gypsum board. The supporting columns on the main floor were protected with a forty-five-minute fire protection wall. In the sanctuary area, the columns were also protected with a one-hour protection wall.

The entire building was framed with prefabricated steel. Transport trucks brought in steel work that had already been prepared in a factory. Once on site, huge cranes lifted each piece of metal, as specially trained and skilled workmen fastened each piece to their designated place. The stage frame was bolted to the foundation walls. That was a typical portal frame elevation. Within four days, the entire structure was completely framed. The metal frame was completed before the concrete work was done on the basement floor. As soon as the walls were built, the men started to pour concrete mixture to finish the floor. Within a few hours after the concrete was poured, the work for finishing the floor commenced to create a smooth surface. 
Workers installed the upper floor in sections. Trailer trucks brought in precast floor slabs, which were then put in place by a huge crane. Each piece of slab was made to fit in a particular location according to design. One by one, a huge crane lifted each piece into place. I watched as each piece was lifted up until the entire upper floor was in place. The roof is a steel design. The joists are made of steel with a load-bearing weight of thirty pounds per square foot.

We had selected the type of flooring for the main sanctuary based on long-term maintenance, safety, and security. Looking at samples of flooring materials and in consultation with the architect, we had decided on color, the quality of material, and the related cost for flooring. We took great care in the selection of the type of floor covering for easy maintenance. For the outer areas such as the Narthex, the entrances, and the hallways, we chose nonslip ceramic tile. Nonslipping tiles would prevent falling during the winter season and rain seasons. Ceramic tiles would also allow for easy cleaning and maintenance. We chose to carpet all other areas of the building for comfort and warmth.

The basement consists of 10,099 square feet of space with 2,800 square feet in the fellowship hall and the kitchen. There is adequate space for the various ministries of the church, including a choir room, a library, and a prayer room. There are also six Sabbath school rooms and three storage rooms. The design included adequate toilet facilities for both men and women. In the men's washroom, there are three toilets, three urinals, and three water closets. In the women's washroom, there are six toilets and three water closets.

The roof is made of steel trusses, which span over thirty feet in center. The ceiling joists bears on the wall and the rafters are also supported from the walls. There is a long 
span of ceiling, stretching sixty feet over the sanctuary floor. It needs a lift for maintenance. Soon after the roof was completed, we found that it leaked. This meant that after the first shower of rain, the interior was flooded. This was a great concern to the members. It took several weeks and several showers of rain to determine the fault. The roof of the church had been divided into two sections. The main section was a pitched roof covered with asphalt shingles on plywood. The second section of the roof was flat and covered with gravel on rubber lining, supported by steel beams. The leaking problem stemmed from the fact that water was accumulating on the flat roof and entering the building through an opening that was made to supply heat into the church. The heating and air conditioning units rested on the flat section. The problem was resolved (and at no cost to the church as the work was still covered under warranty).

\section{Plumbing, Drainage, Heating, Light, and Ventilation}

The mechanical drawings gave the construction details for the plumbing and drainage system, as well as the heating and air system. In the ground floor plan, the plumbing and drainage system was buried under ground before the floors were put in place. The domestic cold and hot water pipe fixtures were installed first. All the underground pipes for the sewer and the waste water were installed. After the upper floor was installed, the sprinkler head and water pipe connections were connected in the garbage room. The pipes were fitted with shut-off valves and backflow switch in the supply lines to the sprinkler.

With respect to heating, light, and ventilation, through a systematic analysis of these interdependencies, we produced an efficient and cost-effective building. For 
instance, we chose the mechanical system based on its ability to impact the quality of the air in the building. As Ellen G. White counsels:

Fresh air is the Lord's great blessing, which, in order to speak the word effectually, every speaker must have, whether it be Sis. White or some other one of the Lord's messengers. . . . God desires his people to study from cause to effect. They should plan for better ventilation. .. It is not His will that those who assemble to worship Him shall be poisoned by the exhalation from the human body. It is a dangerous matter to breathe that which has already been breathed.'

We gave great consideration to ease of maintenance, operating costs, and energy choice. The entire building is serviced by five gas electric units. Four of these units that provide the heat and ventilation are located on the roof outside the building, with easy access for maintenance. One united is located in the basement. The annual service agreement provides service four times each year. We chose forced-air gas over electric heating because of economy and efficiency.

Ducts from the flat roof extend through exterior walls to enter the building. Ducts on the roof are insulated with fiberglass insulation and vapor barrier with black tar covering to prevent the loss of heat. Inside the building, the ducts were mounted to the ceiling and run horizontally through the wall. They were boxed into a bulkhead. Grills facilitate the flow of air through the bulkhead. Exhaust air duct with an opening of 10 by 14 allows for the flow of fresh air into the building. A gas pipe from the outside is installed through the roof to supply gas to the roof-top units. All the gas electric units provide cooling during the hot season, heat during the cold season, and fresh air circulation to the entire building.

${ }^{1}$ Ellen G. White, MS 69, 1900, Ellen G. White Research Center, Andrews University, Berrien Springs, MI. 
The building was designed with the concept of conserving heat and electricity. The heating system is controlled by four automatic thermostats, each controlling a separate section of the building. This way, each section of the building is heated independently, which allows us to heat one section of the building without heating the entire building. In addition, the thermostats have been programmed to reduce the temperature when the building is unoccupied. To reduce dependence of electric lighting, we had two skylights installed over the sanctuary area. This allows natural light into the building during the daylight hours. This way, worship service can be conducted during the daytime without using electricity to give light.

We chose the doors and windows based on their ability to prevent the loss of heat in the winter. All doors are installed with safety devices. The exterior doors are fitted with high security locks to prevent burglary. On the interior, the doors are fitted with panic hardware for easy exits. On the outside entrance, there is a pressure plate for the handicapped entrance. The windows allow plenty of light to enter the building.

\section{Safety Precautions}

We made every effort to ensure that good measures and procedures were in place to protect those who work on the project and for future occupancy. Fire and safety regulations were followed very closely during the construction. A competent superintendent was always on site to supervise the work. Proper material, equipment, and protective devices were always present on the site for accomplishing the work. During construction, we paid special attention to maintenance, clearing the walkway, and removing trash, debris, and any hazardous material to ensure the safety of the workers. 
All contractors and their sub-trades have to wear protective devices for their own safety. We took all necessary precautions to protect the safety of people during the construction process. We clearly identified and marked all entrances and exits. Yellow ribbons were visible, warning of open trenches or obstructions. Proper floodlights were installed at night for safety and security. We required that those permitted to enter the site wore head protection, eye protection, ear protection, foot protection, and those who worked at great height had to wear safety belts and harness to prevent them from falling. We implemented a regular system of inspection to detect and correct any bad habits among the workforce. The site superintendent conducted daily inspections for compliance. All violations were promptly documented and reported to the project manager. We had a fire alarm system installed so that there would be security once we occupied and used the building. All stairs leading to and from the lower level were installed with rails, and all exits are properly designated with warning lights.

\section{Conflicts and Possibilities}

I have already made reference above to some of the conflicts that arose during the building process. More needs to be said about this. Conflicts often arise out of negative behavior, such as inappropriate faultfinding, rumors, misunderstandings, anger, criticism, wrong perceptions, desperation, and selfishness. Conflict is inevitable. It is a natural part of human relationships in the home, in the church, in the school, and in society in general. Conflict occurs when individuals or groups differ in attitudes, beliefs, values, or needs. One of the most difficult times that I faced during the building process was to manage conflict in the building committee. Ellen G. White writes about the spirit of conflict that arose when believers in Healdsburg, California, were considering building a meeting 
house: "As soon as the subject of building ... was mentioned," the believers "began to manifest a spirit of rivalry and selfishly cover the work themselves lest someone outside of Healdsburg should be called to act a part or be made leader in the work."' This shows that conflict can develop even when people are doing the Lord's work.

In our building project, as the builders waited for the bricks, a dispute arose over who should make the final choice. The building committee was unable to make a decision because of a disagreement over the choice of bricks. A divisive spirit arose among the committee members as to the choice of bricks. Meanwhile the builders waited for us to make a decision. The matter ended up taking several days before the committee took decisive action. The problem was finally resolved after consultation with the architect and the budget. I then shared the committee's decision with the church at a business meeting and received approval. In the end, we had chosen a different type of brick than that used in other buildings in the community. I felt that the only way to resolve the dispute was to seek a neutral position that would save the church time and money on the project.

Changing leaders during a building project can be very disruptive, but there came a time in our building project when replacing the leader of the building committee was clearly the only sensible choice to make. I had been very hesitant to suggest any changes of leadership while the construction was going on, fearing this could affect the members' commitment to financial support-so important to making the project happen. After coming to terms with what needed to be done, I nonetheless waited for several weeks, meeting with the committee and trying to clarify their responsibilities to the church. I

\footnotetext{
${ }^{1}$ Ellen G. White, MS 23, 1866, Ellen G. White Research Center, Andrews
} 
even invited the architect to meet with the building committee to provide them with information regarding important choices and decisions that had to be made regarding designs. Certain members became adamant about wanting to have their own way. My patience with the committee was wearing thin.

While the decision to replace the leader of the building committee during the construction process was difficult, I saw it as the only way to prevent delays and extra costs and changes to the work. The church board was sharply divided on the matter, as was the general congregation. Even though the issues were clear to the members, they seemed to feel that this was a personal matter between me, the pastor, and the chairperson of the business committee. Some members sent letters to the conference questioning my character. Other letters began to circulate among the members of the congregation defaming my character. Although it was difficult at times, I did not allow the letters to intimidate me. I presented the facts to the church. I communicated the matter to the conference leaders. The issues were clearly set out to the church. I kept repeating the issues until the message became clear to the members.

Once the members began to better understand the source of the conflict, those who were being most antagonistic began to feel uncomfortable. Although the atmosphere at the church site was tense for a few days, the results were not as destructive as one might have feared. In fact, this conflict resulted in the progress of future work. Once we were able to focus in on the source for the dispute, it became clear that two men had been carrying unresolved anger toward each other for weeks. The conflict was an opportunity for them to express their anger and to build a new relationship. Writing about conflict in

\section{University, Berrien Springs, MI.}


Ministry magazine, H. Jack Morris, has the following to say: "All conflict is not necessarily bad. Conflict that is dealt with, discussed, managed, and resolved can be good. This kind of conflict provides an opportunity for growth and creative change. On the other hand, conflict that is left unattended and ignored can destroy unity, hinder growth, and render ministry ineffective."

While conflicts can be very disruptive and harmful to the ministry of the church, some conflicts can actually lead to a redemptive relationship in Christ. There were several major conflicts that arose while we were in the process of building our place of worship. Many people fear times of conflicts because of the disruption in relationships that they can bring. Whatever the shape and form of a conflict, however, very often, conflict offers the possibility for growth and spiritual renewal. During the time of construction, there were many disturbances resulting from a clash of impulses among members, but the building process was never stopped.

I used to fear conflicts, but I have learned that conflicts can be redemptive. Although there were incidents of criticism, misunderstanding, wrong perceptions and faultfinding during our building project, God demonstrated his redemptive power in the lives of the church members. When proper procedures are followed, the result is usually that people respect each others' opinions, more and cooperation and good will are promoted.

\section{Summary}

A good building design is key to the building of a place of worship. A good design offers detailed descriptions of how the work is to be carried out. The description

\footnotetext{
${ }^{1}$ H. Jack Morris, "Managing Conflict in the Church, 2001," Ministry, May 2001, 5.
} 
must have clear instructions of how and when the work is to be done. The designer and the members should work together to create the most appropriate design. Everyone must be able to understand the design concept so that they will be able to carry out the plan for construction.

The building plan must include several sets of drawings, which outline the space requirements and the function of each space. It is also important to determine the financial plan for the building before work commences. In an age of competition, it is important to compare prices for the same labor and material to be sure that the church gets the proper value for work done. In financing the project, alternate sources of funding must be explored to ease the financial burden on the church.

It takes a good amount of time and hard work to plan and construct a building for worship. Furthermore, conflict is an inevitable part of human relationships. Godly commitment will not prevent criticism or complaining on the job. Nonetheless, when rooted in appropriate theological and biblical principles, and with careful planning, and the commitment, faith, and dedication of all those involved, church-building projects, just like that at the Downsview Church, can be very effective and successful. 
CHAPTER 6

SUMMARY, CONCLUSIONS, AND RECOMMENDATIONS

\section{Summary and Conclusions}

This dissertation outlines the process of constructing a new church building for the Downsview Seventh-day Adventist Church in Toronto, Canada. My hope is that our experiences in the process and the lessons learned can serve to help other congregations design and build appropriate places of worship.

In chapter 1 , I introduce the dissertation in terms of its purpose, the background to the problem it addresses, the problem itself, and the contributions I hope it makes. In chapter 2, I explore the biblical and theological principles, focusing on both the Bible and the writings of Ellen G. White, which provided the theoretical foundation for the construction of the Downsview Church. From these sources, I draw guidance on fiscal, financial, and building construction management. In chapter 3, I relate the history of the Downsview Church, seeking to show how the church began and how it has accomplished its work over the years. I situate the church in its geographic and economic setting and its cultural milieu. I also outline the vision and the trends of the church as well as describe how the vision of a new church building was communicated to the congregation. I further provide an overview of the strategic plan for the building of the new church, including formation of various committees and their responsibilities as well as the selection process for committee members. Finally, I cover the financing of the building project. 
In chapter 4, I examine the various parts of the church's building strategy, including its management and financial strategies. I explore issues related to location of the site, with particular attention to the issue of community accessibility. I review the various sites that were initially considered by the church and explain how the final decision was made to purchase a particular site. I also review the church's future needs in order to determine appropriate size constraints for a new church building and say more about the financing of the building project. In chapter 5, I offer a narrative of the building project, along with a construction schedule. I also consider a range of issues related to the construction process. In this final chapter, I offer my summary, with conclusions and recommendations.

The Scriptures and the writings of Ellen G. White confirm the idea that the building of a place of worship is a sacred commitment. In the Old Testament, Noah, Moses, David, and Solomon all built sacred places for God. In the New Testament, we find useful information on how to build up the body of Christ. Among the principles we find are spirit-filled leadership, the making of plans before you build, and the safety and security of the foundation. Ellen G. White provides advice on almost every aspect of church building, including financing. She counsels that debt can be a hindrance to the work of God and that we must take care not to allow it to prevent the work of building to go forth. She further counsels that the building should be plain, neat, and substantial in design. The place of worship should be built with economy and humility.

These principles and others all became part of the plan to build a place of worship for the Downsview Seventh-day Adventist Church congregation. The design and planning focused on the spiritual mandate given by God. The cooperation of members of 
the congregation, the financing of the project, and leadership were structured according to the spiritual mandate. I believe that the main objectives have been achieved. On June 07, 2003 , as a result of good strategic planning, the congregation began to worship in a new sanctuary. The financial plans worked according to the goals that were set at the start of the project. The budget for the operation and maintenance of the church was within the limit of what the church could safely afford. Since then, the church has been meeting its monthly payment of $\$ 15,000$ on the debt. In addition, there is an operation expense of $\$ 7,000$ each month. The budget for the operation has not overburdened the congregation with too large a debt or put severe limitations on other ministries of the church.

Every congregation needs a place of worship as a supporting structure to carry out the various functions of the ministry. The Bible gives us the theological foundations upon which a place of worship should be established. It is not good to render to God worship in a structure that is being used for unholy purposes. The place of worship must be a learning center for Christian education. Hence, it must be appropriate in form and space. The building must be designed to meet the designated need of the church. Spiritual projects, such as the building of a sanctuary, require spirit-filled leadership. This means leadership with a vision and a commitment to fulfilling that vision. If the vision is clear, the members will share the vision and help in the fulfillment of the plans. Although we faced many conflicts during the process of planning and building of the church, each conflict was dealt with as a natural part of daily living. Furthermore, conflicts were dealt with immediately to avoid long-term problems. In the process, I learned that conflicts can be very disruptive but that oftentimes, when they are managed well, they offer the unique opportunity for redemptive growth and spiritual revival. 
This building project has been a real blessing to my ministry. It has caused me to spend more time studying God's word personally. It gave me great joy to see God's people applying the principles of his words to their daily lives. The sacrificial gifts of the members far surpassed my expectations. I have gained renewed energy in my spiritual life. Thanks to hard work, dedication, and faith, the place of worship was completed according to the plans and the schedules. The people responded willingly and actively and the funding was adequate to complete the project. It gave me a feeling of great satisfaction of a job well done. It is my desire to build another place of worship for the glory of God in the future. As a result of this research, I will adopt a more purposeful plan for my ministry. I will do so in evangelistic outreach, in prayer ministry, and in Bible study.

\section{Recommendations}

I have learned through this project that when there is a clear vision and when the church is organized, even what may seem impossible can be accomplished. In light of the project outlined and documented here, I offer the following recommendations for churches undertaking building plans. Each such congregation should:

1. Develop a plan for building a suitable place of worship that features goals and objectives and identifies priorities. If you fail to plan, you plan to fail. A good plan will create a structure, reduce frustration, save time, and reduce unnecessary costs. All members should be involved in sharing their understanding of the church's goals and mission and be given the opportunity to offer input in plan formulation. The plan should then list the goals and objectives in order of priorities. In formulating the plan, make sure 
to identify applicable divine commands regarding the design and construction of places of worship.

2. Engage all church members in the planning process. The pastor and the lay people should work together to build God's dwelling place. The pastor cannot do it alone. He needs the help of every member in the congregation. Many of the members who are not active will create the most conflict in the church. Write the plan and share the vision with the people so that others will read it and support it (Hab 2:2).

3. Select a visible location that is accessible to persons using major transport arteries and public transit systems.

4. Identify the purpose of the planning process, clarifying the purpose in writing and adhering to it consistently.

5. Proceed on the basis of a clearly articulated budget, raising funds from members of the congregation but borrowing if necessary. The budget might be small at first but as believers hear about it, they will lend their support. Encourage systematic benevolence. If the project needs extra funds, borrow the money to build a suitable place of worship and God will send the help through his people to pay the debt. Faith in God's leading and commitment to his word will inspire the support of the members.

6. Analyze church needs before beginning a building project. Always plan with priorities clearly outlined. List the needs of the church in order of priority. Start with the most important matter first and work your way down the list. Eliminate programs that create distractions. Too many activities can create distortion to the vision of the church.

7. Select an architect and designer carefully, choosing experienced professionals with relevant church-related track records. 
8. Opt for construction over purchase to avoid theologically problematic sanctuary designs inherited from other faith communities. There are many churches without a baptistery. Some have the pulpit set aside on the right and a lectern on the left.

9. Retain pastors for appropriately extended periods to ensure continuity in building programs. In the years prior to my assignment to the Downsview Seventh-day Adventist Church, six pastors had serviced the church for an average of less than three years each. Partly as a result of this, there was no continuity in church plans during this time. As a result, it took the church twenty-four years to construct a suitable place of worship for the glory of God. During my term of service, it took nine years to complete the vision of the church.

10. Plan construction projects in ways that reflect passion for God. Leaders too should have this passion. People are more likely to follow those who believe in what they are doing. Speak commitment, conviction, and dedication. This should all be communicated through both actions and words.

11. Expect conflict and do not fear it. View it as an opportunity for growth that permits the harnessing of different people's energies.

Although my knowledge in the field of church building in the Ontario Conference of Seventh-day Adventist is limited, I have gained much experience from this project. This study is not the end of my work for the church in this conference. It will certainly help me to take on new challenges and opportunities. This study has given me the opportunity to refine my understanding and skills. It has helped me to work more diligently for the churches in my conference and, particularly, in the Toronto area. 
APPENDIX A

PREPARATION OF THE CHURCH:

AN APPEAL TO THE MEMBERS TO BUILD A PLACE OF WORSHIP 
DOWNSVIEW S.D.A. CHURCH

\section{A PLAN FOR BUILDING A \\ CHURCH}

January 1,1995 to

December 31,1996

October 1994

Gods Plan;

A. Exodus $25: 2$ Speak unto the Children of Israel that they bring me an Offering: of every man that bring it willingly..

B. Exodus 25 : 8 And let them make me a Sanctuary that I may dwell among them.

c. Exodus 36 : $4-7$ The people brought more Offering than was needed .........

\section{Spirit of Prophecy Plan;}

A. Testimonies Vol.5 P. 150

"The only means which God has ordained to advance His cause is to bless mankind with property. He gives them the sunshine and the rain; He causes vegetation to flourish; He gives health and abilities to acquire means. In return, He would have men and women return their gratitude by returning Him a portion in Tithes and Offering - in thank Offerings, in Freewill Offerings, in trespass offering"

B. Patriarchs and Prophets p. 529

"The plan of Moses to raise means for the Building of the Tabernacle was highly successful. No urging was necessary. Nor did he employ any of the devices to which churches in our day so often resort. He made no grand feast. He did not invite the people to scenes of gaiety, dancing, and general amusement; neither did he institute lotteries, nor anything of this profane order, to obtain means to erect the Tabernacle for God. The Lord directed Moses to invite the Children of Israel to bring their offering. He was to accept gift from everyone that gave willingly, from his heart. And the offerings came 
in so great abundance that Moses bade the people cease bringing, for they had supplied more than could be used".

God has made mankind His Stewards. The Property (money) which He has placed in their hands is the means that He has provided for the spread of the Gospel.

c. Patriarchs and Prophets P.530

"To promote the assembling of the people for religious

Services as well as to provide for the poor, a second Tithe of all the increase was required .........

This Tithe, or its equivalent in money, they were for two years to bring to the place where the Sanctuary was established". (Deut. 14:23, 29; 16:11-14)

"Every man shall give as he is able, according to the blessings of the Lord thy God which he hath given thee."

Deut. 16:17

D. Testimonies Vol.3 P.389-390

This plan is called Systematic Benevolence.

"If this plan of systemic Benevolence were adopted by every individual and fully carried out, there would be a constant supply in the Treasury. The income would flow like a steady stream constantly supplied by overflowing springs of benevolence".

Christian Service P.204

"Where, in God's directions for the support of His work, do we find?

Any mention of Bazaars, Concerts, Fancy Fairs and

similar

Entertainments?"

Christian Service P.205

"All these methods for bringing money into His Treasury are an abomination to Him. It is a spurious devotion that prompts such "devising."

Testimonies Vol. 4 P.474

"Of all our income we should make the first appropriation to God."

THE DOWNSVIEW PLAN;

Income

God's Tithe

My Offering

Myself
$\$ 100.00$

$\$ 10.00$

$\$ 10.00$

$\$ 80.00$
$1 / 10$

$8 / 10$ 


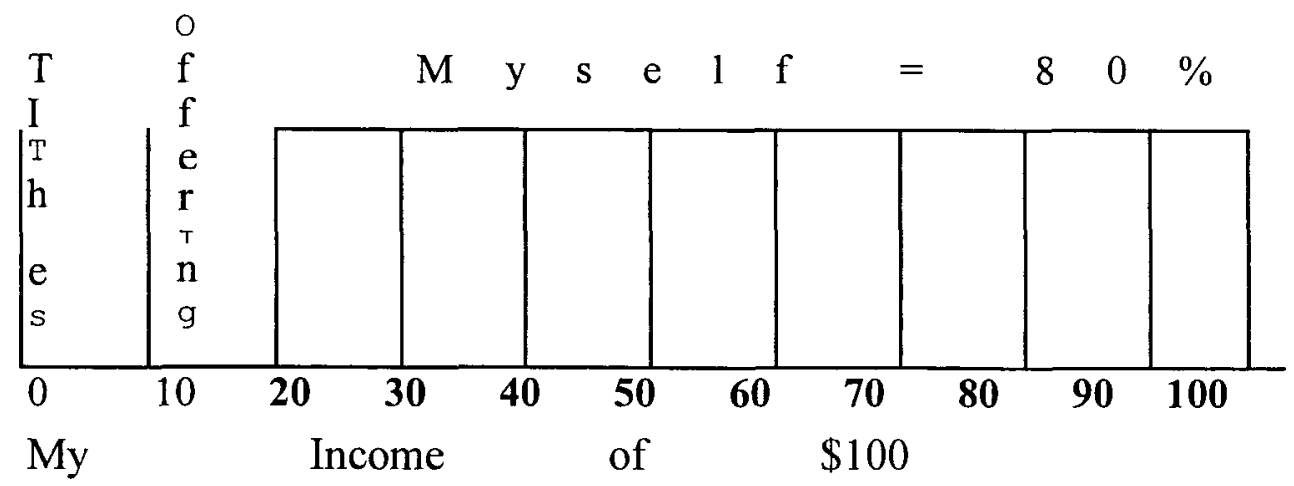

\section{Projections;}

1995 Project Income $\ldots \ldots \ldots \ldots \ldots \ldots \ldots \ldots 200,000.00$

Less Church Operating Expense............\$50,000.00

Total for Church Building ........... \$150,000.00

1996 Project Income ................ \$200,000.00

Less Church Operating Expense .......... \$50,000.00

Total for Church Building ........... \$150.000.00

Total Projection for 1995 and $1996=\$ 300,000.00$ 
Proposals for Building

Downsview S.D.A. Church

To build or not to build?

\section{Problems facing the Church}

- Lack of rooms for teaching our children in Sabbath school.

- Overcrowding in the foyer after church service.

- overcrowding during foot-washing service at communion service.

- Lack of office space for church administration.

- No fellowship hall for church fellowship and kitchen.

- High cost of heating portables.

- The declining conditions of the portable buildings.

- The present church building is not visible from the street by visitors.

- Visitors are lost frequently, when searching for the church.

- The present building makes it difficult to advance the work and mission of the church.

\section{Erecting a new church building}

- A new building will attract new people to the church.

- A new building will inspire church member to worship. A new church building will unify our members behind a significant challenge

- The new building will make a statement to the community about our Church's mission

- A new building will provide our people with a more effective tool for ministry.

- This new building will be a visible witness throughout the week to all who pass by.

- As an effective witness to the community, this church site needs to be properly developed.

\section{Financial Challenge}


- The giving pattern of the church needs to be consistent

- Individuals and families need to give systematically.

- There is a need for more emphasis on the biblical

pattern of giving.

- Contributions to the building fund should not affect the regular contribution to church budget.

\section{Reasons to give thanks to God}

- We owned a valuable piece of property.

- The cost of this property is has doubled in five years.

- The value constantly increasing.

- There is good access to public transportation.

- There is adequate space for parking.

- Church membership is growing.

- Most church members are employed.

- Now is the time to prove God.

\section{Reasons for building now}

- The cost of construction material is rapidly increasing.

- The cost of building permit is increasing each year.

- Labor cost is going up.

- The city population is growing fast and church space is needed.

- Interest rates on loans are still low.

- God is testing our stewardship.

- 155 persons giving \$25.00 each week can build a church for 2 million dollars in 16 years.

- God can do much with little gifts.

The supply in their hands may seem to fall short of the need to befitted; but in the hands of the Lord it will prove more than sufficient,.. A greater faith in the onward progress of His cause in the Earth- this is the greatest need of the Church today. (Prophets and Kings p. 243)

- We should go forward in Faith

Ellen White said: We all need to be wide-awake, that, as the way opens, we may advance the work in the large cities. We are far behind in following the instructions 
to enter these cities and erect memorials for God. We are to continue working until a church is organized, and a humble house of worship is built. (Evangelism p. 379).

- People who are not of our faith will help.

"I am greatly encouraged to believe that many persons not of our faith will help considerably by their means. The light given me is that in many places, especially in the great cities of America, help will be given by such persons". (Evangelism p. 379).

- The building should be plain, reat and perfect in design.

"We have no command from God to erect a building which will compare for riches and splendor with the temple. But we are to build a humble house of worship, plain and simple, neat and perfect in its design". (Evangelism p. 377).

- A building will assure a stable work.

"Where-ever a company of believers is raised up, a house of worship should be built. Let not the workers leave the place without accomplishing this." (Evangelism p. 376).

- The children should be provided for.

Workers in new territory should not feel free to leave their field of labor till the needed facilities have been provided for the children under their care. Not only should a humble house of worship be erected, but also all necessary arrangements should be made for the permanent establishment of the church school (Evangelism p. 380).

- We can borrow money to build.

It is right to borrow money to carry forward a work that we know God desires to have accomplished. We should not wait in inconvenience, and make the work harder, because we do not wish to borrow money. (Counsels on Stewardship p. 278).

- We suffer great loss because of a lack of Faith.

Let us not give the impression that we find it too great an expense to provide properly for the reception of the heavenly Guest. In laying plans for building, we need the wisdom of God. We should not needlessly incur debt, but I 
would say that in every case, all the money required to complete a building need not be in hand before the work is begun. We must often move forward by Faith, working as expeditiously as possible. It is through a lack of faith that we fail of receiving the fulfillment of God's promises. We must work and pray and believe. We are to move forward steadily and earnestly, trusting in the Lord, and saying, "We will not fail nor become discouraged". (Counsels on Stewardship p. 280). 


\section{Downsview Seventh day Adventist Church Strategic Guidelines for Fund Raising}

1 Cor. 4: 2

"Moreover it is required in stewards that a man be found faithful."

Psalms 50:5 "Gather my saints together unto me; those who have made a covenant with me by sacrifice".

1. Plan $10 / 10$

a. That each Church member be Faithful to God and return a faithful Tithe.

b. That each Tithe paying member sacrifice a second $10 \%$ each month for the Church budget.

c. The Church budget is used to finance all the ministries of the Church, including the paying of the mortgage.

2. Personal pledges:

a. Members who desire to do more than just the $10 / 10$ have pledge a lump sum for the building project

b. Some have pledge for the pews and other items in the building.

c. It is required that those who make pledges should honour their commitment to God. God takes every commitment seriously.

3. Plan 25

a. That each member set aside $\$ 25.00$ each week for the Church Building Fund. That amounts to $\$ 100.00$ each month per member.

b. The Church Building Fund is used for the paying of the mortgage and to complete the construction.

c. This Plan $\mathbf{2 5}$ does not include God's Tithe and the Church budget of $\overline{f e r} i n g$.

4. Solicitation

a. Members are given letters to solicit funds from family and friends of Downsview SDA

b. To solicit funds from co-workers and business people.

c. Building contractors are asked to contribute to the project by discounting their labour.

5. Project Planning: (This plan is optional)

a. Individuals, who are inspired to raise additional funds for the church by planning Concerts, bake sales, banquets, yard sales etc. These should not be promoted during the worship service of the Church because they are not consistent with the spirit of sacrifice.

b. Promotions of such projects during the worship service can destroy the spirit of Sacrificial giving and unity, which is vital for the Spiritual health of the church.

c. Let us all remember that God requires a sacrifice offering; and those who promote projects should first make a sacrificial offering, and not rely on the proceeds from these projects to finance the work of God. 
Letter to Business

February 21, 2003

Dear

The new Downsview SDA Church building is in the final stage of construction, and we need your help to purchase one or two pews at a cost of $\$ 900.00$ each.

It is truly amazing to see how God has touched the hearts of the people who are working on the construction of the new Downsview Church. Even though they are not members of this Church, God is using them to make a significant contribution for His glory.

One contractor donated his trucks to remove soil from the site, when asked how much for the work, he said, "I cannot charge God".

The owner for the company that received contaminated soil from the site said, "I have to do something for the Church." He cancelled all charges, which was in the thousands of dollars. Another contractor made a large donation to the church building fund and said, "God has blessed me in my business, and I have to return something to the Church.

A tradesman came out one Sunday morning from 6:00 A.M. and volunteered his time to help members put up the frames in the basement, he said, "My mother taught me from I was a child, to do something for the Church.

Would you like to join those who have helped us, by purchasing a pew or by making a tax-deductible gift to our new Church Building project?

Your gift of [ ] $\$ 1000.00 ;$ [ ] $\$ 2,000.00 ;$ [ ] $\$ 5,000.00 ;$ [ $1 \$ 10,000.00$ other $\$$ is greatly appreciated.

May God truly bless you for your generous contribution.

Yours Sincerely,

Kenneth Campbell

Pastor 
February 12, 2003

Dear Eellow believers,

The Downsview Church Building is in its final stages and we need your help urgently.

We need to purchase 74 new pews for the Sanctuary, and to install carpets and tiles on the floors. The cost for each pew is $\$ 900.00$.

It is truly amazing to see how God has touched the hearts of the people who are working on the construction of the new Church. Even though they are not members of this church, God is using them to make a significant contribution for His glory.

One contractor donated his trucks to remove soil from the site, when asked how much for the work, he said, "I cannot charge God".

The owner for the company said, "I have to do something for the Church" He cancelled all charges, which was in the thousands of dollars.

Another contractor made a large donation to the church building fund and said, "God has blessed me in my business, and I have to return something to the Church.

A tradesman came out one Sunday morning from 6:00 A.M. and volunteered his time to help members put up the frames in the basement, he said, "My mother taught me from I was a child, to do something for the church.

I thank God for these experiences. I am truly inspired as I see those who are not of faith responding to God's love for his Church. As you can see, the work is almost completed; we need to make one last push financial.

If you have not yet played a part, now is the time to make your contribution. Your gift of $\$ 500.00 ; \$ 1000.00 ; \$ 2000.00 ; \$ 5,000.00 \mathrm{can}$ make a difference; please respond by April 30, 2003.

Thank you in advance.

God bless you for your faithful and generous contribution.

Sincerely yours in Christ Service,

Kenneth R. Campbel1

Pastor 
March 10, 2003

Dear Pastor

S.D.A. Church Board Members,

The Downsview Seventh-day Adventist Church is requesting your help in purchasing one or more pews for its new Sanctuary. The cost for each pew is $\$ 900.00$.

Since 1979, the Church has begun the process of planning to build a Place of Worship for God. Iike ancient Israel, the Church has wondered from place to place, meeting in homes, in schools, in rented churches and community centres.

In 1996, the Church purchased an old industrial building, which was converted into a place of worship. We have experience many inconveniencies in this old building especially with ministering to our children and youths. This situation has forced us to construct a new Sanctuary. We must thank God for the sacrificial offerings of our members and friends, which have brought us to this point of near completion.

As you know, the cost of Construction is very expensive and we have had several cost overruns in this project. We trust that you will do whatsoever you can to help.

Your generous contribution will help to encourage us and to make this a reality.

Thanks very much for your kind donation.

Yours in Christ Service,

Kenneth R. Campbe11

Pastor 
Letter of Reminder to those who made Pledges

August 8,2002

Dear

I am writing to let you know that your financial pledge for the building of a new place of worship was greatly appreciated. Thank you for your support of the Downsview Seventh-day Adventist Church building initiative. It is certainly at a sacrifice to your personal needs that you have made this commitment to the Lord. I want to assure you that heaven will bless your gift of support.

As you can see, the building plans are progressing well. We give God thanks for what He has enabled you to do so far. If you are making weekly, monthly or lump sum contribution, May the Lord bless you as you continue your support for the progress of His work. We are hoping that the new Building will be ready by the end of December 2002. This of course is based on us receiving your pledge to complete the necessary work.

Please remember to carry some contribution envelopes and when the opportunity presents itself, request donations from family members, friends, business associates and co-workers.

I have no doubt that with God's help we will see the completion of this building. We shall also see many precious souls coming to join themselves with Christ in preparation for His soon return. I think of the time to come when our children and grand children shall ask us about this Building, we shall tell them of the sacrifice that was made and how the Lord has blessed us.

I pray that God's blessing will be with you and your loved ones as we build a memorial for the glory of God.

Thanks for your Contribution.

Yours in Christ Service

Ken Campbell

Pastor 
October 27,2002

Treasurer: Ulysses Guarin

Ontario Conference of Seventh-day Adventist Church

1110 King Street East

Oshawa, Ontario L1H 1 H8

Dear Elder Guarin,

This letter is to inform you that the Downsview Seventh-day Adventist Church has accepted the Funding Requirements as outlined in your letter of October 25, 2002, in regards to the Royal Bank loan of $\$ 790,000.00$.

The purpose of the loan is to complete our new Church Building for a place of worship. Because this is a construction loan, is it possible that we could begin the repayment at the end of the construction, instead of on November 14, 2002? Please advise us.

Downsview Seventh-day Adventist Church

By:

Kenneth Campbell

Church Pastor

By:

Lorna Dixon

Church Treasurer 
APPENDIX B

ESTIMATING THE COST FOR THE BUILDING PROJECT

PROPOSED ESTIMATES FOR THE COST

OF THE NEW BUILDING 
First Estimate

11-Jan-02

\section{ABCO CONSTRUCTION \\ ESTTMATES}

Project: Downsview Seventh-Day Adventist Church

\begin{tabular}{|c|c|c|}
\hline TEMS & DESCRIPTION & COSTS \\
\hline & Excavation \& Backfill & $89,210.00$ \\
\hline \multirow[t]{2}{*}{$4105 \mathrm{~m} 2$} & Asphalt, Line Painting, 1 Inch Topping & $33,000.00$ \\
\hline & Curbs, sidewalks $110 \times 45245 \mathrm{~m} 2 \times 60$ & $19,650.00$ \\
\hline \multirow[t]{31}{*}{$55 \mathrm{~m} 2$} & Parking Bumpers & $2,750.00$ \\
\hline & Landscaping & $3,000.00$ \\
\hline & Sodding (Grass) $150+50+102+70+135+255+155+400+770$ & 4.890 .00 \\
\hline & Concrete Work \& Finishing - Basement Foundation \& & $146,000.00$ \\
\hline & Core Slab - Floor Between Basement and Sanctuary & $72,700.00$ \\
\hline & Rebar \& Mesh - Steel Work 24000+9x250 & $26,250.00$ \\
\hline & Masonry - Reinforced Bricks \& Blocks & $139,550.00$ \\
\hline & Structural steel Framing \& Deck & $113,700.00$ \\
\hline & Miscellaneous Metal, Railings & 5.500 .00 \\
\hline & Wood Stairs & $1,860.00$ \\
\hline & Carpentry \& Trusses - Roof Framing & $87,000.00$ \\
\hline & Millwork $7 \times 80+2 \times 50$ & 650.00 \\
\hline & Roofing \& Flashing $1160 \mathrm{SF}$ & $9,300.00$ \\
\hline & Shingles & $16,000.00$ \\
\hline & Eave Troughs, Gutters \& Soffits & $9,000.00$ \\
\hline & Hollow Metal, wood Doors & $15,500.00$ \\
\hline & Hardware Cash Allowance & $16,000.00$ \\
\hline & Aluminum Windows, Doors \& Front Door & $35,000.00$ \\
\hline & Skylights & \\
\hline & Handicap Operator $2 \times 2500$ & $5,000.00$ \\
\hline & Drywall, Metal Studs, stucco Ceiling & $180,000.00$ \\
\hline & Vinyl Composite Tiles, Ceramics & $65,000.00$ \\
\hline & Painting & $30,000.00$ \\
\hline & Washroom Accessories, Toilet Parts & $6,000.00$ \\
\hline & Baptistery & $6,000.00$ \\
\hline & HVAC - Heating, Ventilation, Air Conditioning & $1.50,000.00$ \\
\hline & Plumbing & $39,000.00$ \\
\hline & Site Services - Sewers & $40,000.00$ \\
\hline & Electrical & $130,000.00$ \\
\hline & Overhead General Account Foreman / Onsite & $68,050.00$ \\
\hline & Project Management Fees & $70,000.00$ \\
\hline
\end{tabular}

TOTAL

$\$ 1,635,560.00$

\begin{tabular}{|l|l|l|l|}
\hline Extra & Costs & & Not incl \\
\hline & Appliances & & Not Incl. \\
\hline & Architectural Fees & & Not incl \\
\hline & City Fees & & Not incl. \\
\hline & Electrical & & Not incl \\
\hline
\end{tabular}




\begin{tabular}{|l|l|l|l|}
\hline & Furniture's - Pews & & Not incl \\
\hline & Skylights & & Not incl. \\
\hline
\end{tabular}

Second Estimate

Downsview Seventh-day Adventist Church

For Preliminary Budget only

Prepared by Doris Cheung Architect

(Three comparisons)
Size of Lot in Acres

Size of Building in Sq.ft.
2.00

23,724

\subsection{0}

23,724
2.00

23,724
Scheme "A"

$\$ 2,016,540 @ \$ 85 /$ sq.ft
70,579

$\$ 2,087,119$

\section{Scheme "B"}

$\$ 1,897,920 @ \$ 80 /$ sq.ft. 66,427

$\$ 1,964,347$
Scheme "C"

$\$ 1,779,300 @ \$ 75 /$ sq.ft.

62.276

Sub Total

$\$ 1,841,576$
)

Storm Water Service $\quad 5,000$

Sanitary Connection $\quad 8,000$

Water \& Fire Connection 3,000

Hydro connection $\quad 8,000$

Telephone

Gas connection

Sub Total

$--$

24,000

5,000

8,000

3,000

8,000

$--$

$--$

24,000

24,000

C. City Charges

Site plan Application Fee $\quad 1,478$

Building Permit Fees

Sub Total

44,079

44,557

1,478

44,079

45,557

1,478

44,079

45,557

5,000

8,000

3,000

8,000

$-\cdot$

D. Consultants Cost

Prime Consultants (Architect, Structural engineer, Mech.\& elect. Engineers)

Fees $\quad 78,500$

Storm water management 1,000

Surveyor

1,000

Sub Total

$\mathbf{8 0 , 5 0 0}$

78,500

1,000

1,000

\section{Construction Budget}

Contingency $(10 \%)$

$$
2,237,176
$$$$
223,718
$$

$2,114,404$
78,500

1,000

1,000

80,500

$1,991,632$
199,163 


\section{Downsview Seventh-day Adventist Church Budget Estimates for New Building}

Trades

Price

Excavation/Backfil

Site Services

Asphalt Paving

Landscaping

Concrete Formwork

Concrete Supply

Concrete Finishing

Concrete Rebar

Structural Steel

Miscellaneous steel

Steel Deck

Masonry

Coreslab

Trusses/Lumber Supply

Labour

Asphalt Roof

Drywa11/Acoustics

Windows /Glazing

Hollow Metal doors/Erames

Finish H/dware/Toilet Acess

Millwork

Baptistry

Pews

Painting

Flooring

Electrical

Plumbing/Heating

Street Connection

Site Supervision

Project Management fees

Miscellaneous Labour Cost

Environment Tests

Building Permits

Architects/Consultants Fees

Total

$\$ 1,866,131$
Bid price

PST

$\$ 78,100$

$\$ 47,161$

$\$ 133,750$

$\$ 22,000$

$\$ 86,750$

$\$ 52,000$

$\$ 15,000$

$\$ 21,000$

$\$ 126,000$

$\$ 14,200$

$\$ 4,200$

$\$ 168,000$

$\$ 465,500$

$\$ 50,000$

$\$ 65,000$

$\$ 22,000$

$\$ 220,000$

$\$ 40,900$

$\$ 6,450$

$\$ 15,930$

$\$ 10,000$

$\$ 15,000$

$\$ 75,000$

$\$ 28,000$

$\$ 45,000$

$\$ 95,108$

$\$ 186,500$

$\$ 80,000$

$\$ 50,000$

$\$ 40,000$

$\$ 30,000$

$\$ 9,000$

$\$ 40,000$

$\$ 78,000$

$\$ 2,017,599.00$
Revised

$\$ 68,000$

$\$ 45,761$

$\$ 133,750$

$\$ 22,000$

$\$ 82,000$

$\$ 36,000$

$\$ 9,000$

$\$ 18,000$

$\$ 106,400$

$\$ 8,600$

$\$ 4,200$

$\$ 166,000$

$\$ 65,000$

$\$ 50,000$

$\$ 40,000$

$\$ 22,000$

$\$ 189,000$

$\$ 40,900$

$\$ 6,450$

$\$ 15,930$

$\$ 10,000$

$\$ 15,000$

$\$ 75,000$

$\$ 28,000$

$\$ 43,532$

$\$ 91,108$

$\$ 174,000$

$\$ 99,000$

$\$ 30,000$

$\$ 40,000$

$\$ 30,000$

$\$ 9,000$

$\$ 40,000$

$\$ 78,000$ 


\section{APPENDIX C}

A MASTER PLAN FOR BUILDING A PLACE OF WORSHIP:

COMMUNICATING THE PLANS TO THE CHURCH 
Downsview Seventh-day Adventist Church

$$
\frac{3 \text { Year }}{\frac{\text { Master }}{\text { Plan }}} \frac{1997-1999}{}
$$

There is a Greek proverb that says; "Before you can score, you must have a goal." Harold J. Seymour once said "It is what you do ahead of time and how it is done that usually decides whether you win or lose."

The wise man Solomon said, where there is no vision the People perish" Prov. 29:18 The purpose of a Master Plan is to outline the Goals, Procedures and Strategies of the Church for the next three years in order to solicit the support of every member. When our goals and objectives are clearly defined, it will be easier for us to work together on common grounds.

\section{Mission:}

We are a Spirit directed people, committed to share the Everlasting Gospel of Jesus Christ with the Community and the world.

\section{Seven Essentials of the 3 Year Plan}

\section{Spiritual Growth:}

To encourage every member to seek a deeper experience with Christ through:

Daily Bible Study, Prayer and Witnessing.

To help each member to discover his/her spiritual gifts and to use those gifts for the Building up of the body of Christ.

To conduct Seminars and Workshops on subjects that will encourage Faith maturity in

Believers. Seminars on topics such as Marriage, Family Life, Parenting, Health and Temperance, Stewardship, e.t.c 
The Pastor and Church Elders to know the Spiritual condition of every Church Member

within the next three years.

That every non-attending Member be encouraged to transfer their Membership to the

Church they are presently attending and that those whose address cannot be found be dealt with according to the policies of the Church.

\section{Evangelism:}

To conduct one joint Tent Crusade in 1997

To install Satellite to participate in Net 98 Evangelism

To conduct one joint Tent Crusade in 1999

To encourage every member to win one soul for Christ

3. Church Building:

As our Church continues to grow each year, it is necessary for us to plan for the expansion of our physical facilities. To build a new Sanctuary as a part of Phase 2 Capital Development.

This project to include such facilities as mother's room, Kitchen, offices, fellowship hall and a new Foyer.

\section{Church Leadership:}

We need to continue to train and equip Christ-centered Leaders who are committed to take charge of the various departments or the Church.

\section{Youth Ministry:}

The youths are our greatest assets and our greatest challenge.

We must mobilize our youth for greater service in the Church and in the community.

To encourage and promote Christian Education as a priority for all our youth.

To help young people to develop skills that will help them to meet the challenges of the future. 
To reward each Student in the Church School with $(\$ 500.00)$ who maintain an average of "A" for the School year. (This fund to come from student Aid fund). To assist where possible, those student who have dropped out of School, with counseling. Youth Pastor for full time work.

\section{Church Music:}

To adhere to the guidelines set out in the Church Manual and the Spirit of Prophecy. To avoid all worldly conduct and presentations in music during the worship Service. To set out clear and definite guidelines for Church Music by the end of 1997.

\section{Church Finance:}

To extend the Plan 10/10 for three year to the end of 1999.

To promote the involvement of every Church member as a faithful steward..

That the Church Building Funds be set aside for Phase 2 Development; and that the Mortgage payment be taken from Church Budget.

To encourage every Member to participate fully in their support and finance of the work

of the Church.

These plans shall be reviewed and evaluated yearly to ensure that we are staying on course. 


\section{DOWNSVIEW S.D.A. CHURCH QUESTIONS ABOUT THE TWO YEAR PLAN}

October 29, 1994

What is this "Two Year Plan"?

The Two Year Plan is a serious initiative taken by the Downsview S.D.A. Church on October 22,1994, to involve every member in Soul-winning and Fund-raising for two years.

Can you explain the Soul-winning part of the plan?

The goal of this plan is to Baptize 50 new members and to reclaim 10 former members. To accomplish this, we will conduct two Crusades, one in the spring of 1995 (April 1-22 1995) and the other in the fall of 1996.

What is the Fund-raising part of this Plan?

This plan calls for Commitment, Dedication and Sacrifice. This plan can be called plan 10/10. It simple means that whenever we return God's Tithe we give a second 10\% for Local Church Expense. 75\% of this amount will be reserved for Church Building.

Do I give other offerings when I give my second 108 ?

This second $10 \%$ will cover all the Local Church Offerings, such as Sabbath School Expense, A.Y. Offerings Building Fund and any other offerings that stay in the local Church. It does not include Ontario Advance Offerings, World Budget Offerings or Sabbath School Mission Offerings.

What is the goal of this new Plan?

First of all, this Plan is not new, it is an old plan, and it is in the Bible. Moses used the plan when God instructed him to build the Tabernacle in Exodus Chapters 25-36; some people gave as much as $331 / 3 \%$ of Income. The Plan was so successful that Moses had to stop the people from giving. Secondly, if every member supports this $10 / 10$ plan, we will have more than $\$ 300,000.00$ in our Building Fund by December 31, 1996, by this time we are determine to find a new Church Home.

How do I give this offering?

Put your offering in the special Envelopes that will be provided or if you use Chegues you can put it in the Tithe Envelopes under Church Budget. Do not put the second $10 \%$ in the same place as the Tithe.

When should I start giving to this Plan?

You can start now, but our launching date is January 1, 1995. Remember God loveth a cheerful giver. 
What about the Pledges that I have made before?

This plan replaces all other forms of fund-raising. This includes Concerts, Dinners, Pledges, and partners. We are praying that everyone will follow this $10 / 10$ plan. It is from the Bible, and it is called SYSTEMATIC BENEVOLENCE. 


\section{A Pastoral appeal to the church}

May 31, 1995 we closed the sale for the purchase of 37 Bakersfield. St.

On May 12, 2002 we plan to have a ground-breaking Ceremony for a new Sanctuary.

This year will be exactly seven years since we acquire this property .

God has put us in a unique position. He has put us on the front line in Evangelism.

God has called us to preach the Gospel to thousands of people.

He has called us to reclaim former Adventists.

We had the advantage of hosting the first Tent Evangelistic Crusade in Canada in 1996. Since then we have seen many miracles. As long as we continue to act in obedience to God's call, he shall bless us even more.

\section{Financial details:}

In Ezra 7: 7, 8 we read that now is the time to build. We need $\$ 500.000$ before May 31, 2002 in order to get a loan through the Conference to start the building. So far only 25 persons responded to an appeal with pledges totaling $\$ 48,000.00$.

I believe that we can do better than that. Of the 500 members in our church, only 25 have responded so far. We need every member to help us bear the responsibility.

I believe that if "Church building" becomes a priority, Money is no problem. 
If I consider a house to be a priority in my life, whatever it cost I will buy it.

If I consider a car to be my priority there is no problem

If dress is a priority, there is no problem

If a 32" TV is a priority there is no problem.

If going on a vacation in the Caribbean is a priority, there is no problem.

If a computer is a priority, there is no problem

If furniture is a priority, there is no problem

Therefore, if the Church is our priority, there is no problem with money. We need to see the value of having a New Church. We must give the best to God.

We need adequate space for ideal worship

We need a place that is beautiful

A place that is warm and comfortable

A place that is perfect in its design

A place that is neat and convenient.

We need to become more aggressive about building a House of Worship for God. I would like to ask of you "let us work together?"

I also ask everyone to pray that God will enable you

to do something now. Let us prove God? 


\section{Downsview Seventh-day Adventist church Plans for 2002 and beyond}

1. To establish God's word in the minds of believers as the criterion to all church ministries and personal living.

2. To assist each department to develop goals and objectives for their ministries, with the clear purpose of fulfilling the mission of the church.

3. To equip all elected leaders for service and personal growth.

4. To motivate lay members to witness through their personal testimony and through the word of God.

5. To expand the local congregation through the building of a new place of worship and to successfully plant a new congregation in the next two years.

6. To motivate young people to live their lives based upon the simple principles of God's word, instead of following the trends and fashions of the modern age.

7. To raise the heart of each believer through the plan of systematic benevolence.

8. To plan the Church programs in every department based upon a weekly, monthly, and yearly theme.

9. That our yearly theme should be "Living by the Word"

10. That there is a fixed time each month, once each quarter during the year for each department to meet for planning and to coordinate their programs with the rest of the Church activities.

11. To promote Church Growth based upon the following

A. Membership Goals:

2002

2003

2004

2005

2006 
B. Baptismal Goals:

2002

2003

2004

2005

2006

C. Sabbath School Attendance Goals:

2002

2003

2004

2005

2006

Haggai 1:8 Go up to the mountain and bring wood and build the Temple.

Hab 2: 2 "Write down the revelation and make it plain on tablets, so that a herald may run with it".

Nehemiah 2:18 Let us rise up and Build...

\section{What are our options?}

\section{Project Manager:}

Become the project developer on behalf of the church, taking a more active role in moving the project from concept to completion.

\section{Design/Construction:}

Turn-key Project

\section{Design/Construction with Volunteer Program}

Drywall,

Carpentry,

Painting,

Electrical,

Clean up services Carpeting and

tiling, Plumbing.

\section{Advantages of Volunteer Services}

The volunteer program provides several excellent advantages to the church:

1. The workers get a feeling of ownership in the church. 
2. Personal relationships are made with fellow workers that can last a lifetime. When you are working side by side, you come to know your fellow Christians in a way that you may never have had a chance to before.

3. Many individuals learn that they can do more than just "go to church". They can become part of the church.

4. The church historically grows $10 \%$ to $20 \%$ during a building program. All the reasons for this are not known; however, we suspect it is largely due to volunteers talking about the project to people to whom they normally would never mention their church.

5. Many of our volunteers have been husbands who normally do not attend church services with their families. Working on the building project provides them with a way to feel they can participate and contribute to the church.

6. And, of course, tens of thousands of dollars can be saved on construction cost. 


\section{Organizing the Members for Church Ministries}

\section{Coordinator for Supportive Ministries: \# 1}

Communion Service; Ordination of Elders; Public

Relations; Religious Liberty; Human Relations.

\section{Coordinator for Supportive Ministries: \#2}

Deacons;

$$
\text { Deaconesses; Socials; P.A. System }
$$

3. Coordinator for Supportive Ministries: \# 3

Baby Dedication; Greeters; Hospitality;

Music; Bulletin; Library; Church Clerk.

4. Coordinator for Supportive Ministries \#4:

Finance Committee; Building Committee; Treasury;

Stewardship.

5. Coordinator for in reach Ministries:

Prayer and Fasting; Wednesday Night

Prayer Meeting; Sabbath Bible Class.

6. Coordinator for Youth Ministries:

Adventist Youth; Pathfinders;

Adventurers; Children's Ministry; Christian

Education.

7. Coordinator for Adult Ministries;

Family Life; Women's Ministry; Health and

Temperance; seniors. Men's Ministries.

8. Coordinator for Outreach Ministries:

Personal Ministries; Sabbath School;

V.B.S.;

Community Services;

Interest Coordinators; Investment Leader. 
APPENDIX D

BUILDING PROCEDURES SET OUT BY THE

SEVENTH-DAY ADVENTIST CHURCH 


\section{Building Procedures}

1. Form a local building committee to develop plans.

2. Inform conference development officer of your plans to build

3. Approve preliminary building plans in business session

4. Send preliminary plans to Conference building committee

5. Review recommendations with local building committee

6. Re-submit plans to building committee to be passed on to Conference Executive Committee for approval.

7. Secure financing (if necessary) and begin project.

\section{If land purchase is necessary,}

make any offers to purchase subject to Conference Executive Committee approval with sufficient time for building committee and Executive to consider your plans. 


\section{PROPERTY PURCHASING \\ AND \\ BUIIDING POLICIES PRELIMINARY \\ PREPARATION BY CHURCHES}

Approved April 29, 1990

The church board studies and votes the church building intent and presents it to church in business meeting. The election of the Building and Finance Committee could take place at that time.

The Building and Finance Committee will establish size and facilities needed, approximate square footage, and estimated cost.

It would be a good idea to remember that churches must be current in school subsidies and conference accounts before approval for building or purchasing will be granted.

At the church board or business meeting at which a definite sale or purchase decision is made, a representative of the Ontario Conference (normally the Development Director) must be present.

\section{PROCEDURAI POLICIES}

A.

PRE-PIANNING

Phase I - Letter of Intent

Send a letter of intent to Conference Church Development Director by September 1, prior to year that funds are needed.

NOTE: The letter is to include the following items:

1. A description of the total building project and estimated cost. Submit a plot plan and rough conceptual plan only. (Should not cost more than $\$ 250.00$ ) (See appendix B)

2. A completed Church Building Survey of Needs form attached to this policy. (See appendix C) .

3. A statement indicating that the Building Policy has been read and that this project has been approved by the church and/or school board in business or constituency meeting, dated and signed by the pastor and board chairman. 


\section{PLEASE DO NOT:}

1. Hire a lawyer. The Ontario Conference's lawyer will act on the church's behalf. DO NOT:

2. Hire an architect at this point. DO NOT:

3. Prepare detailed plans. 
Building

Policies

\section{Phase II - Conference Committee Review}

Following receipt of your letter, the Conference Building Committee will study your project, and if the concept is approved you will be authorized to proceed with preliminary Building plans.

\section{Phase III - Preliminary Building and Financial Plans}

A. PRELIMINARY BUILDING PLAN

Once approval and comments are received on conceptual plans and the Church Building Survey of Needs, the Ontario Conference can guide you in hiring an architect ( we are currently working with some and they may save you some money) to do:

\section{a. An accurate dimensional site plan.}

b. A dimensional preliminary plan of the building

outlines. showing approximate room

\section{B. PRELIMINARY FINANCIAL PLANS}

Prepare a preliminary financial plan and include the following information:

1. Cost Budget Sheet. One will be given to you.

a. Estimated cost of building or buildings including permit fees. b. Estimated cost of carpeting and furnishings (exclude pianos and organ) . c.

Estimated cost of site preparation. d. Estimated cost of off-site improvements. e. Estimated cost of on-site improvements

(sidewalks, walls, etc.). f. Estimated cost of all utilities and sewer connecting fees. g. Estimated cost of parking lot, landscaping and identification sign.

h. Estimated cost of public address system. i. Total estimated cost of project. 
Building

Policies

HI- FUNDS NEEDED - BEFORE CONSTRUCTION APRROVAL

A. Land must be paid for before approval for construction will be given.

B. Fifty percent (50\%) of the total cost of the project, excluding cost of the land must be in hand in cash. The remaining fifty percent (50\%) should be arranged for in the form of a loan (Revolving Fund) or should be in cash, before construction begins. The annual church budget must include sufficient funds for church expense, school subsidies, all church programs and repayment of building loans.

IV - BUYING EXISTING BUIIDING

When purchasing and existing building, $60 \%$ of the total cost must be in hand, in cash.

V - PRIORITIZATION OF CONFERENCE FUNDS

All Conference appropriations to a project are allocated on a priority basis as funds are available. Projects that have been given final building and financial plan approval by the Executive Committee will be placed on a prioritized list.

VI. - LIMIT OF CONFERENCE EUNDS

If funds have been allocated by the conference but not used, the proposed project will be reviewed at the beginning of the following calendar year to see if it is still planned. If it is not going to be done during that year, the funds may be transferred to another building project.

\section{VII- BORROWING POLICY}

A. When borrowing funds for a construction project the Ontario Conference Conmittee approval must be obtained. The annual church budget must include sufficient funds for church expense, school subsidies, all church programs and repayment of the building loan.

B. The maximum amount a church may borrow is based on $200 \%$ of its annual tithe. 
C. Maximum time for loan repayment is 8 years.

D. The Revolving Fund interest rate is $81 / 2 \%$ and is a variable rate.

E. This loan will be subject to the availability of funds.

APPENDIX B

a. Conceptual Site Plan with approximate dimensions.

b. Show streets.

c. Show entrances and exits to property.

d. Insert location of building or buildings on plot plan in rough scale.

e. Write name of building on plot

plan.

f. Show parking area.

It can be in pencil or felt pen. 
APPENDIX E

PICTORAL NARRATION OF THE NEW DOWNSVIEW SEVENTH-DAY ADVENTIST CHURCH FROM GROUNDBREAKING TO COMPLETION

(JUNE 2002-JUNE 2003) 


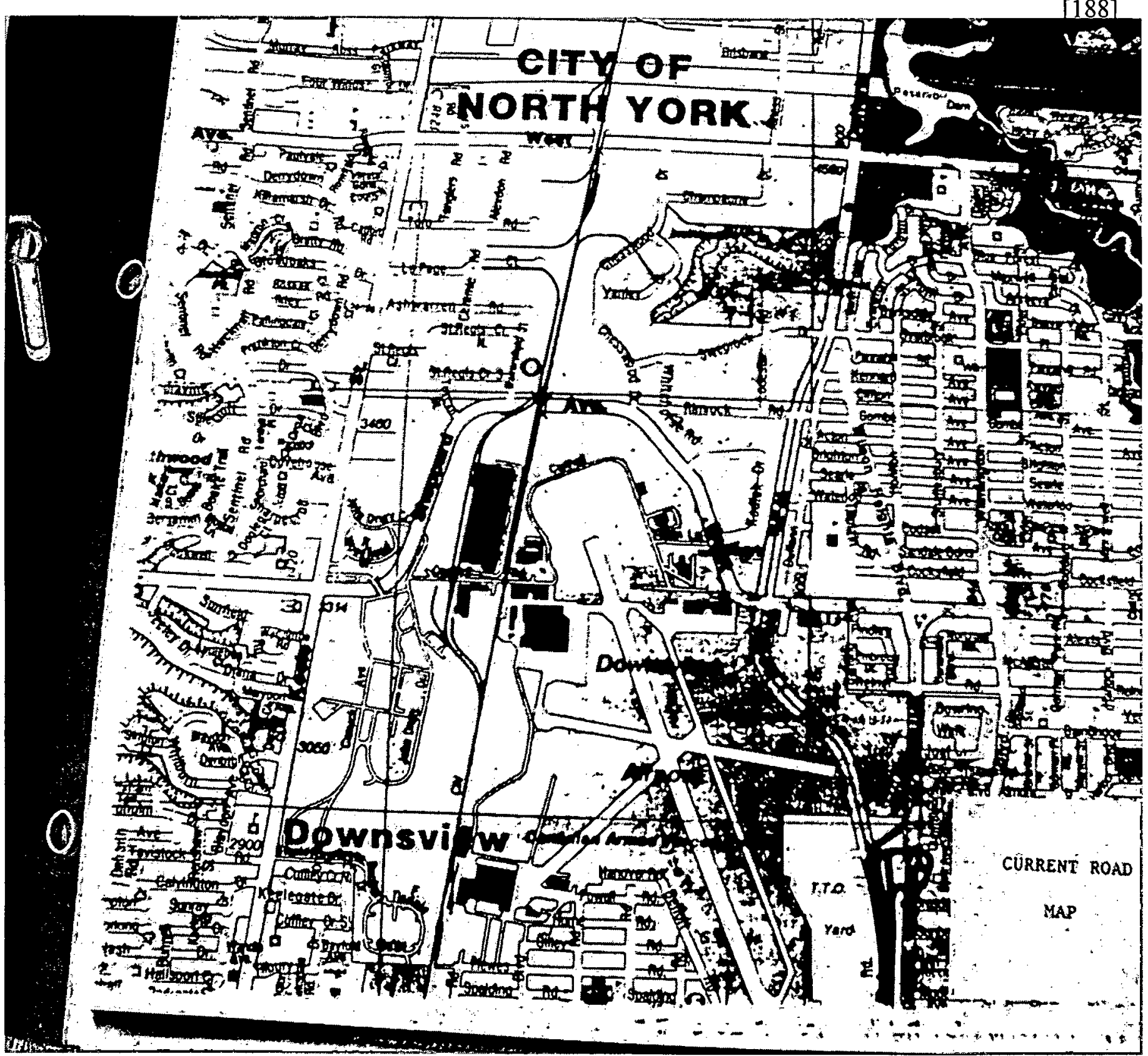

Current City Map with Church location as 0 on Map 


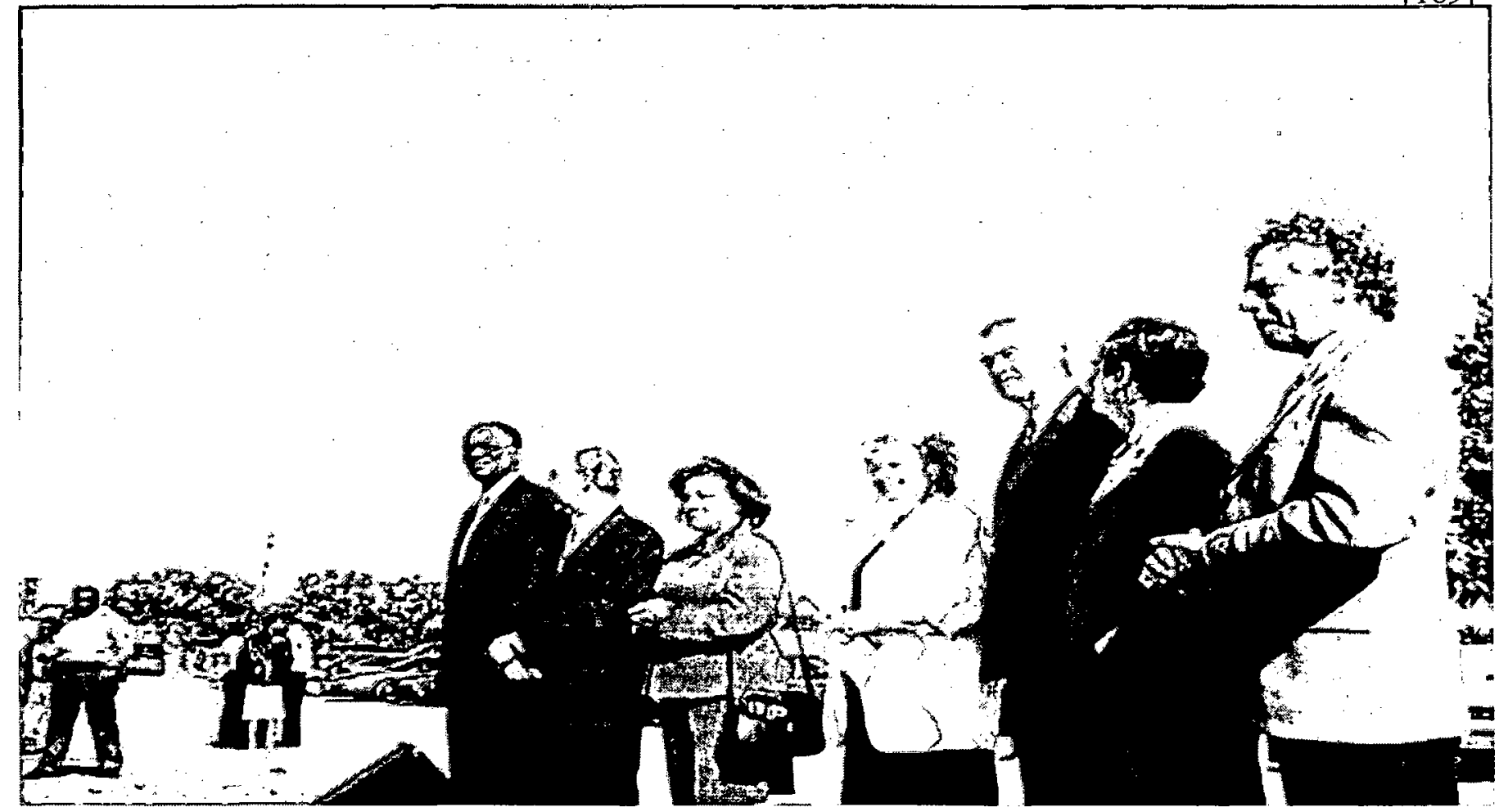

From Left: Pastor, President and Wife, Conf. Secretary and Wife, City Counsellor, and Member of Parliament.

These officials standing in the outdoor Ceremony before engaging in the breaking of ground for the new Sanctuary building.

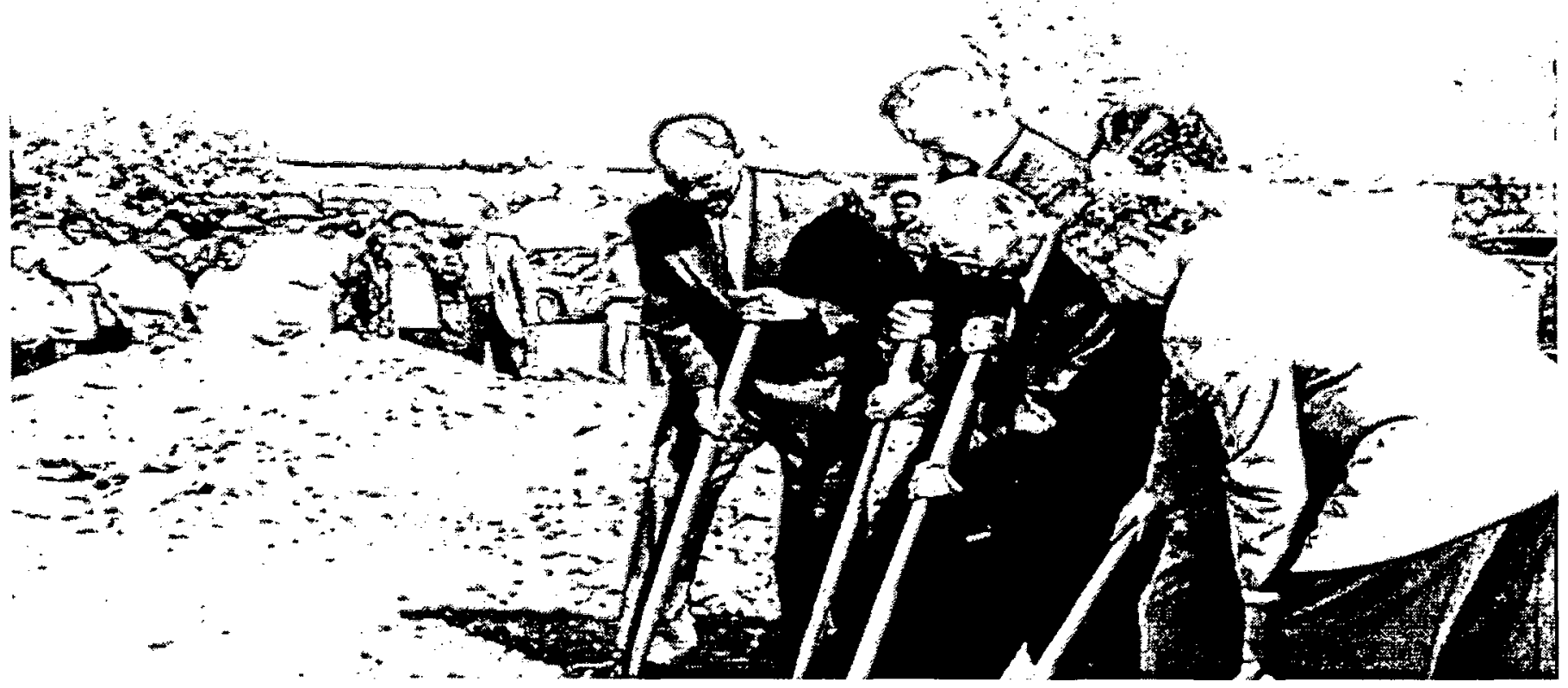

From Left: The Pastor, Secretary, President and City officials breaking ground for the new building. 


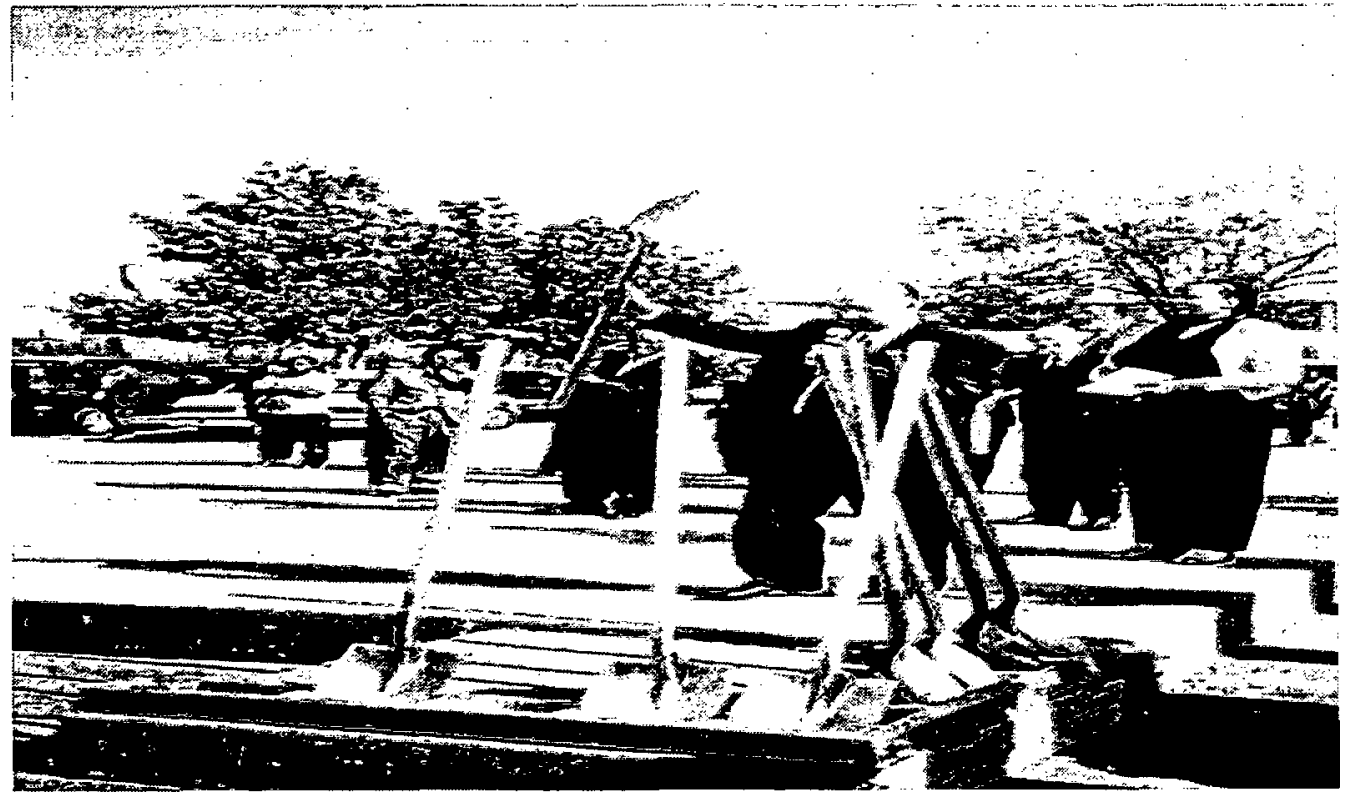

The President of the Conference is holding up his shovel after breaking ground.

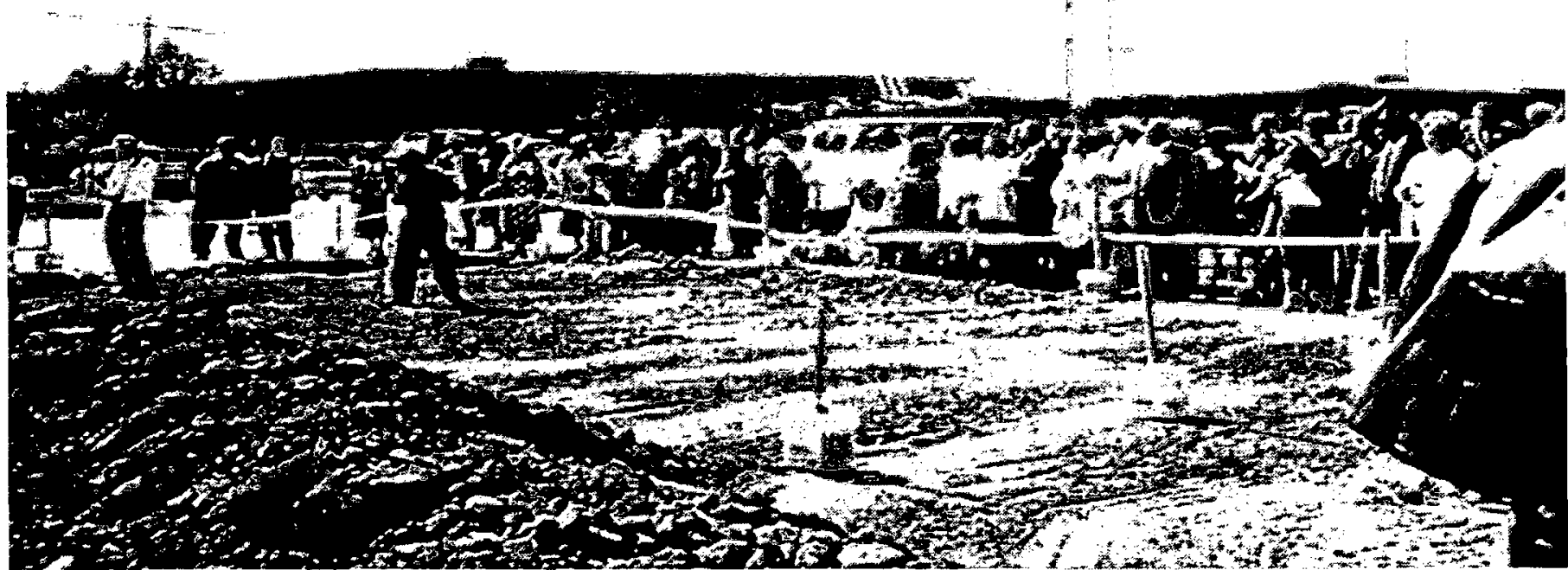

The Members of the Church gathered around the special site that was selected for the ground breaking Ceremony 


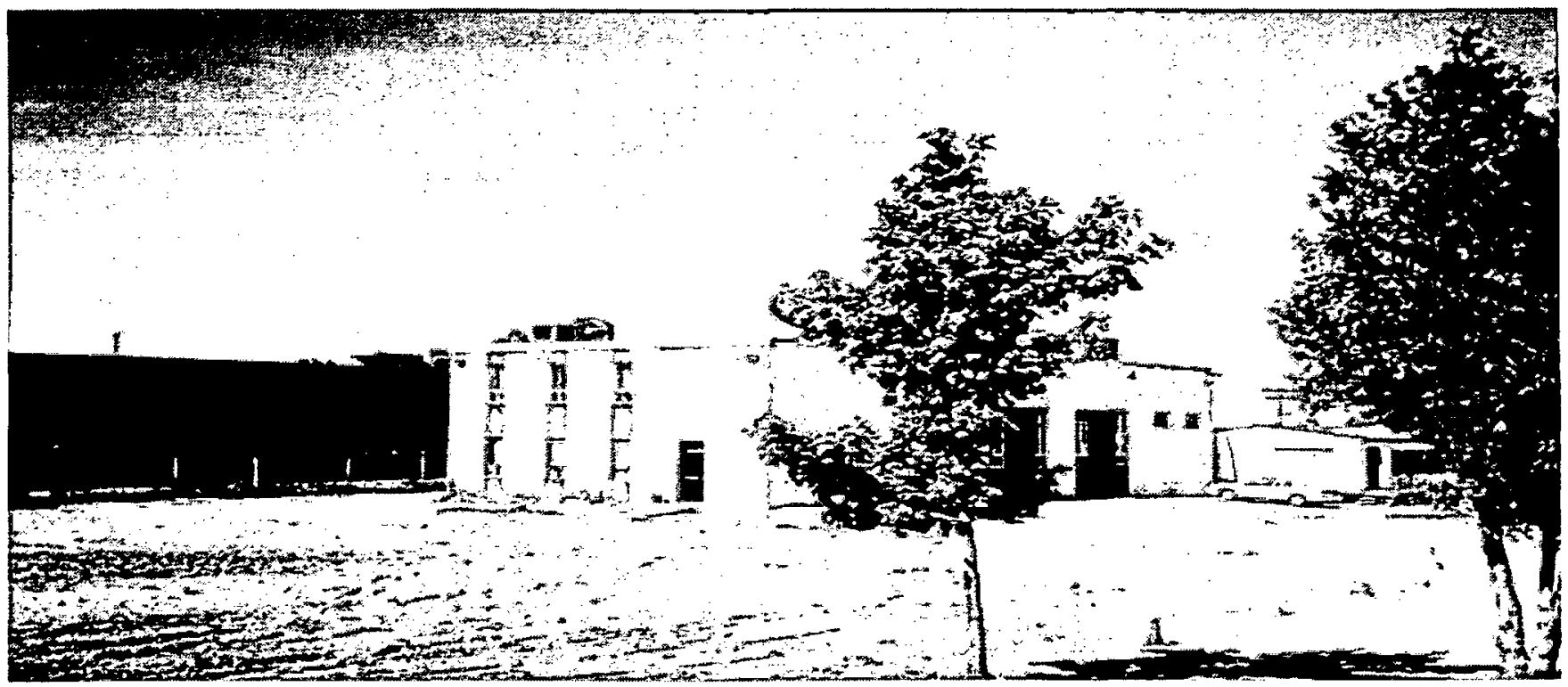

The first building owned by the church, it was used as a starter home for the congregation before the building of the new sanctuary. This building was good for a start, but it was not the best that the members wanted do for God, They wanted a new Sanctuary.

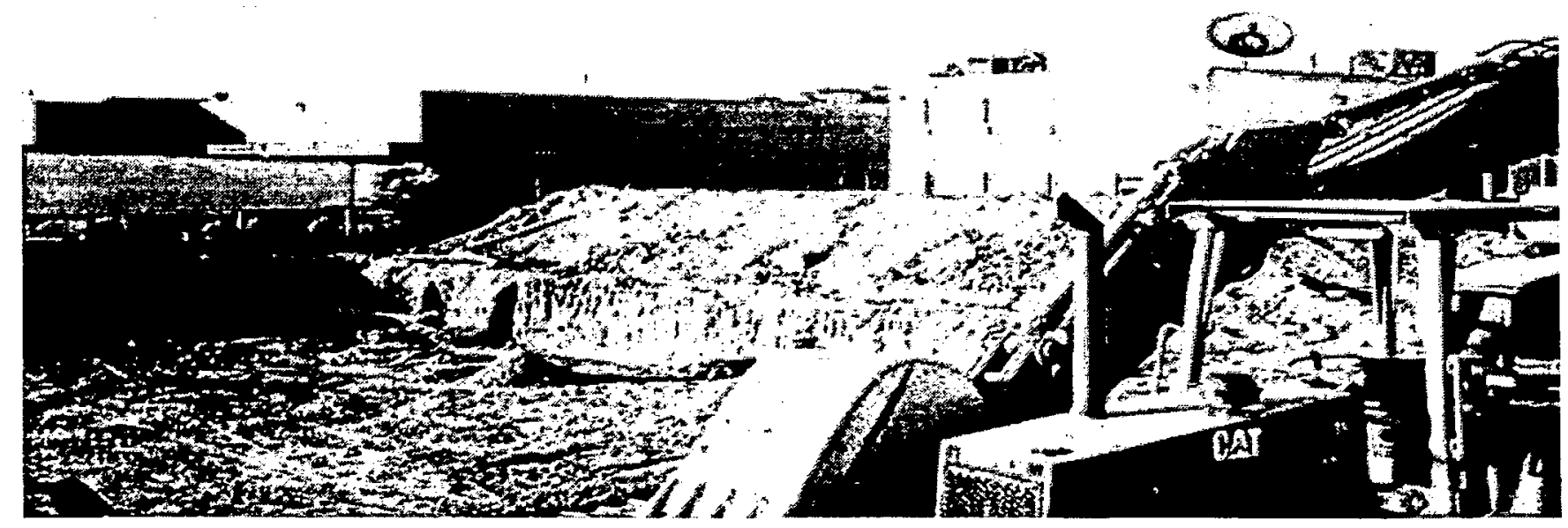

This is the work of excavating of the site for the foundation of the building. 


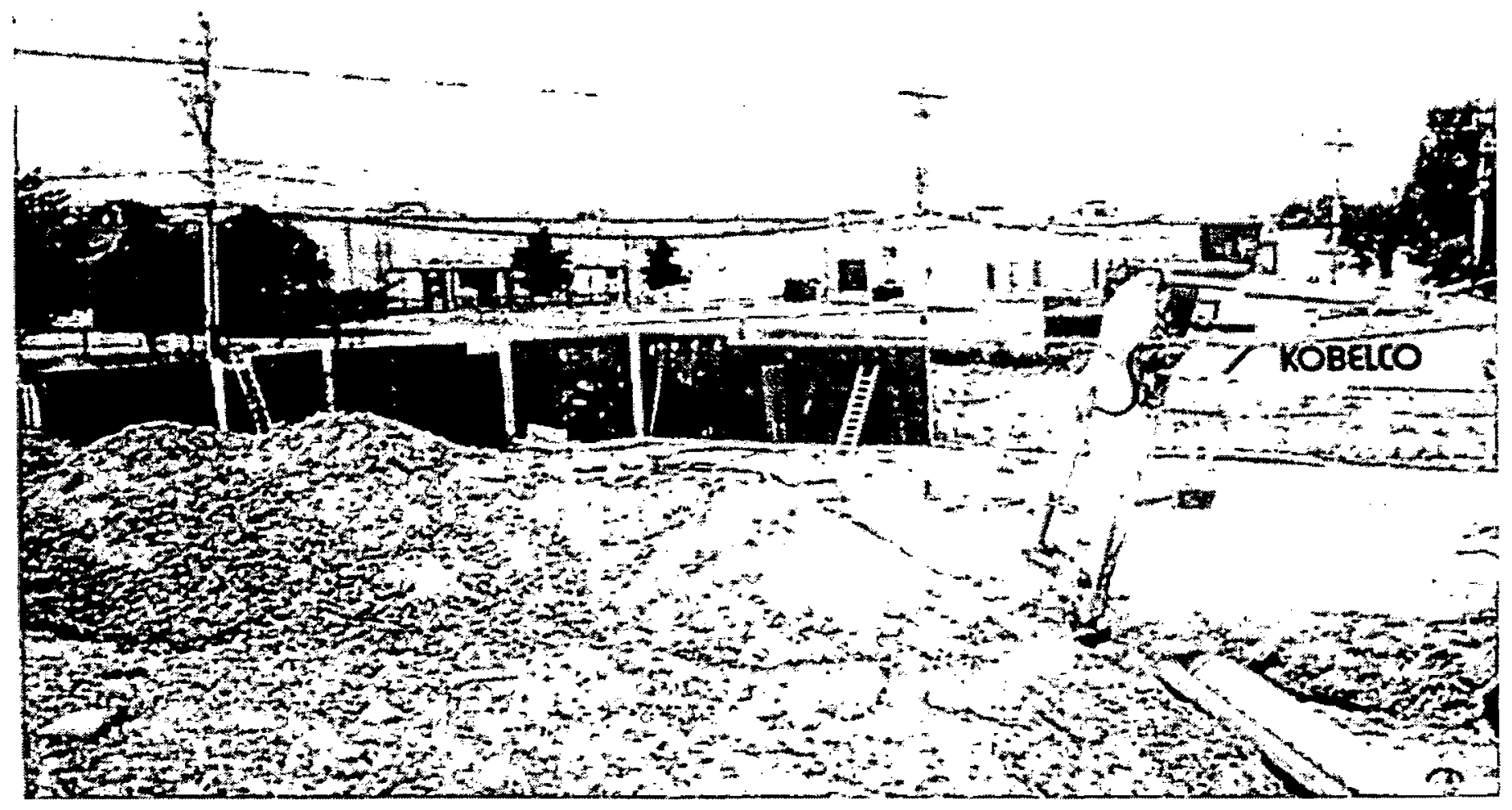

The sanitary services were installed before the foundation walls were laid.

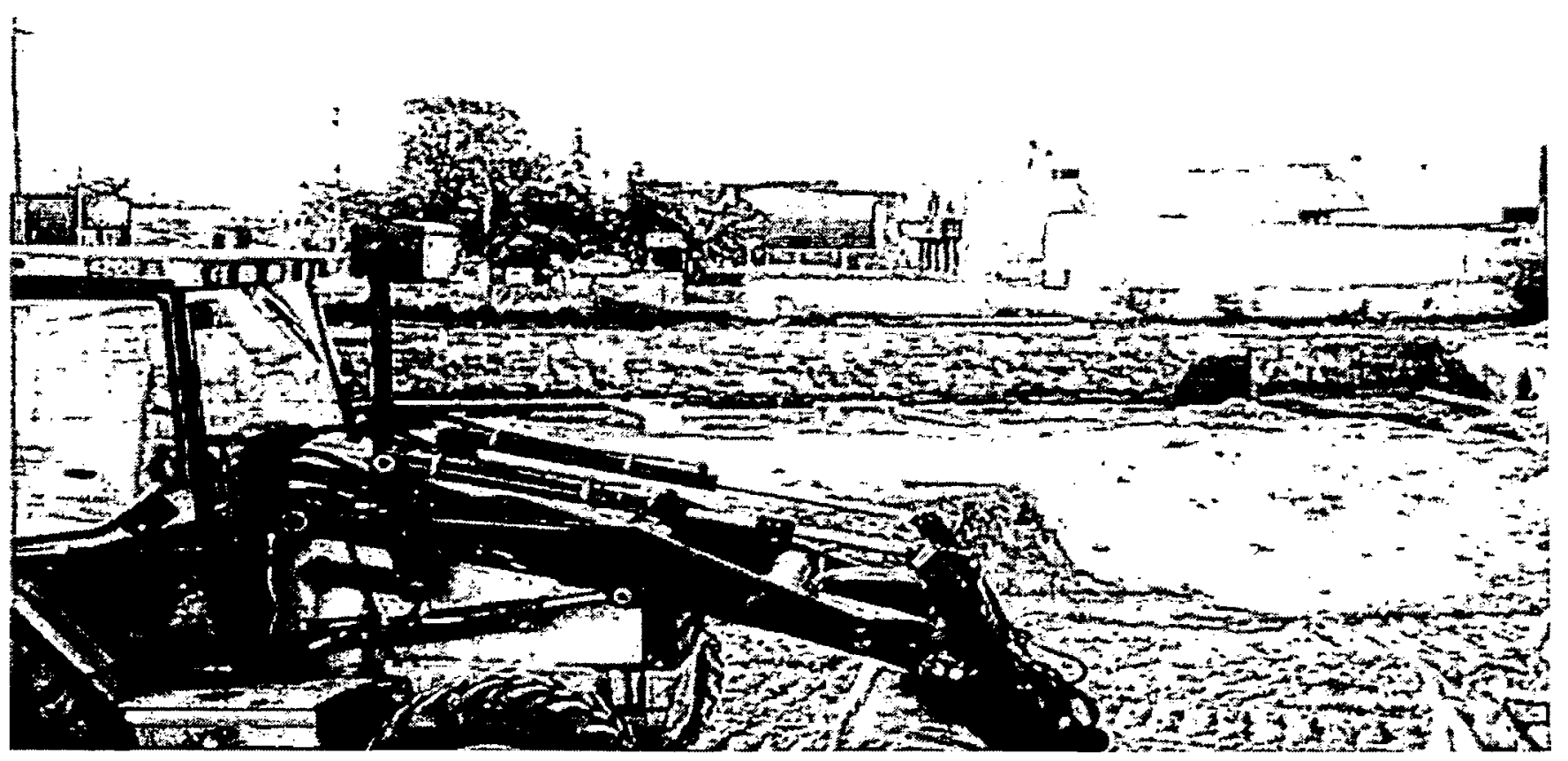

Preparing the ground for the pouring of the foundation walls. 


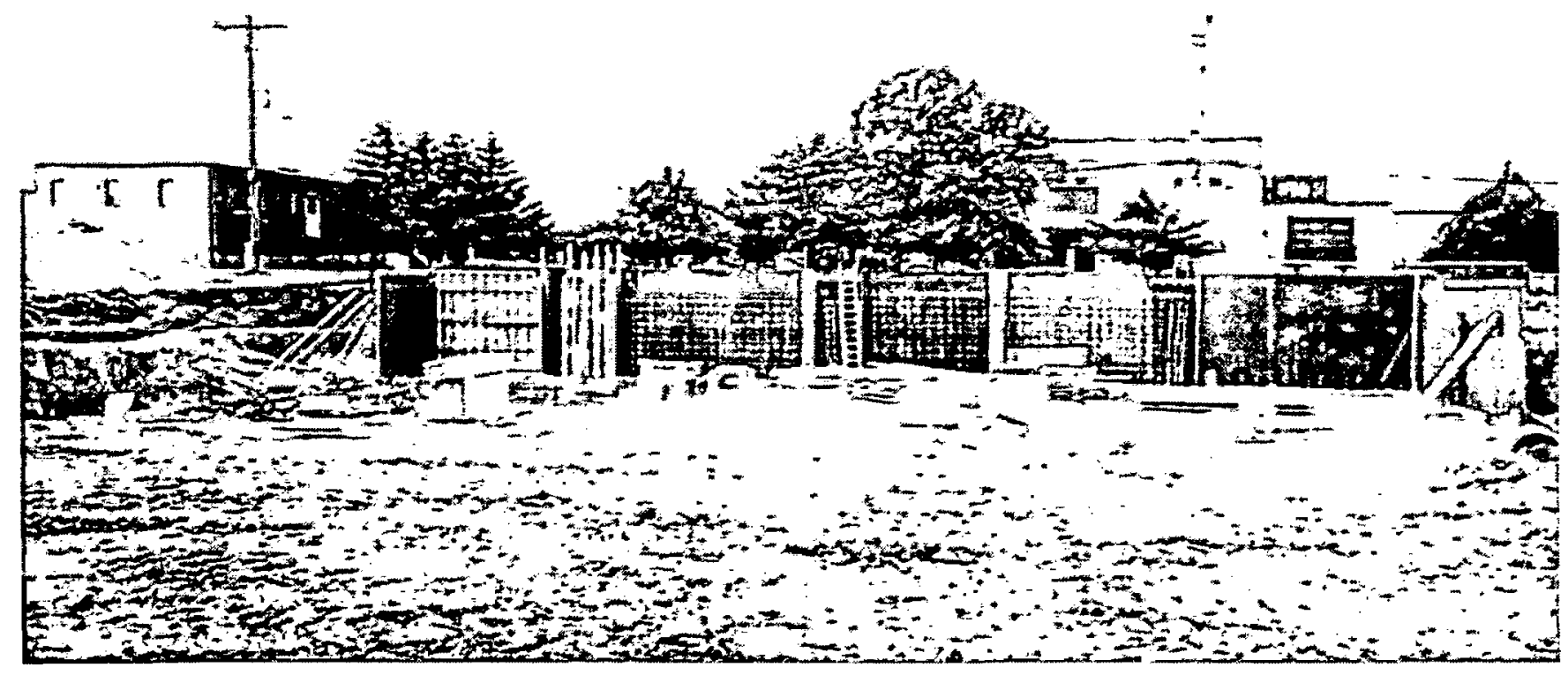

Above: The form work was put in place before the concrete was poured.

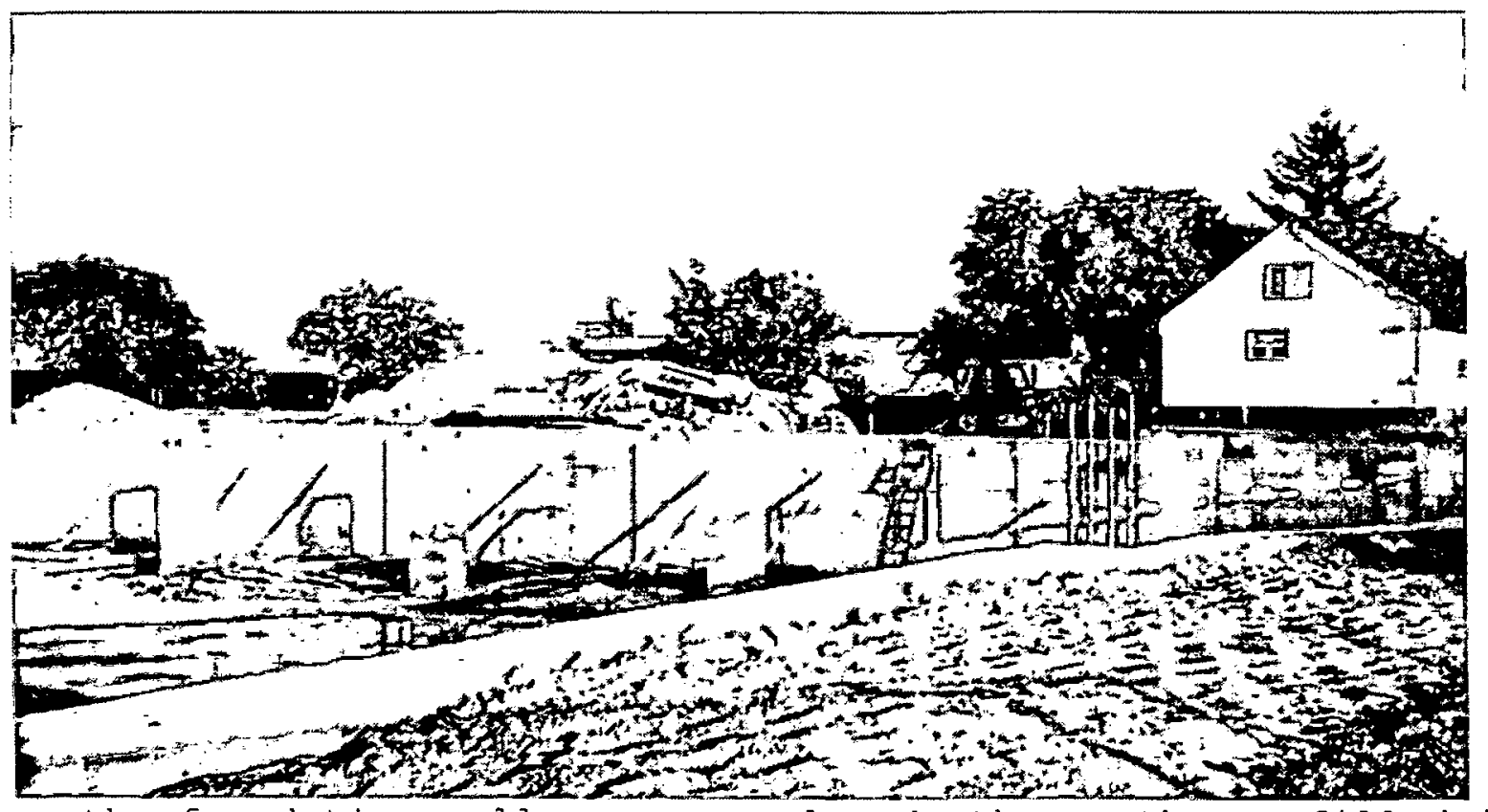

When the foundation walls were completed, the earth was filled in around the foundation. 


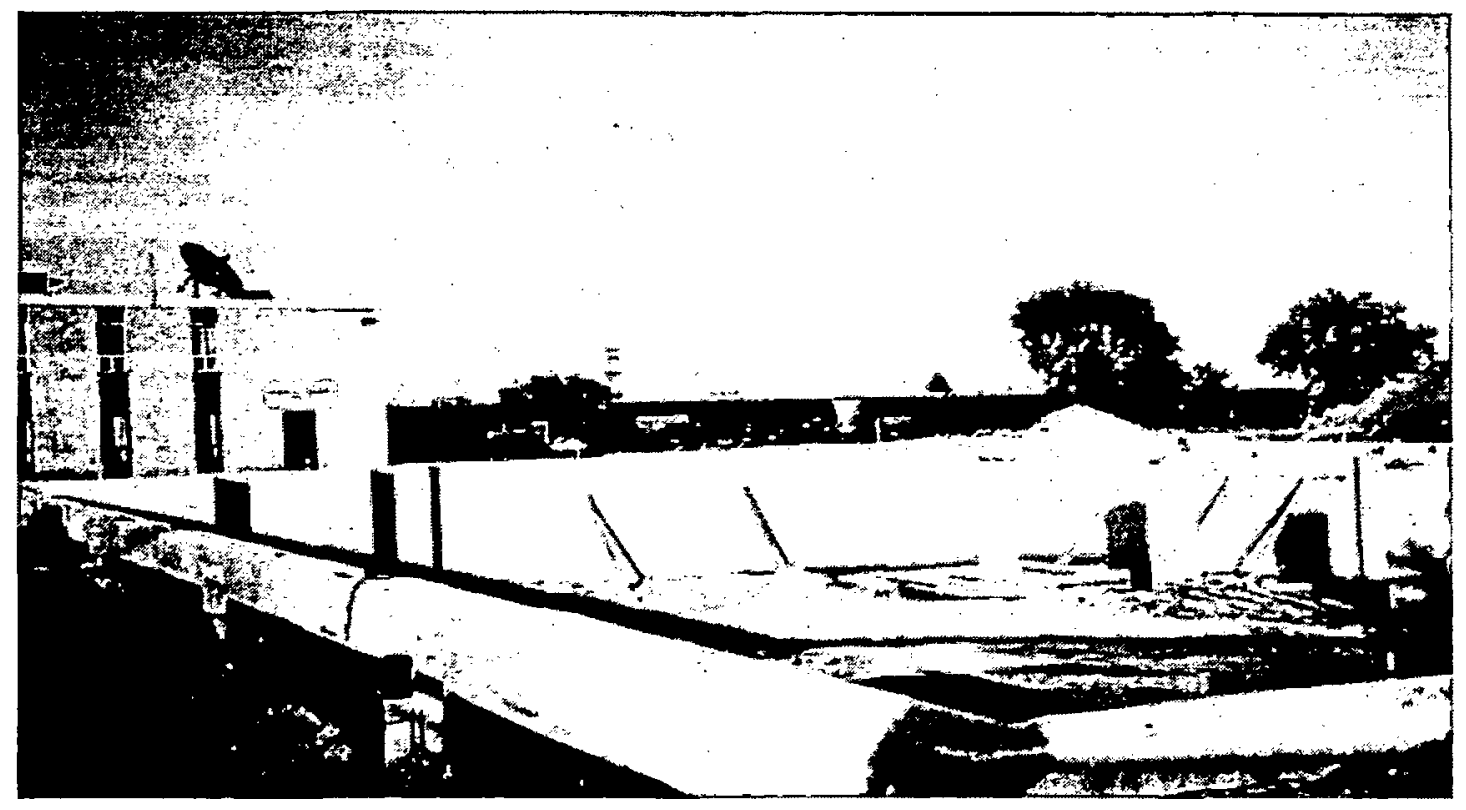

$[194]$

The walls for the foundation were 14 inches in diameter.

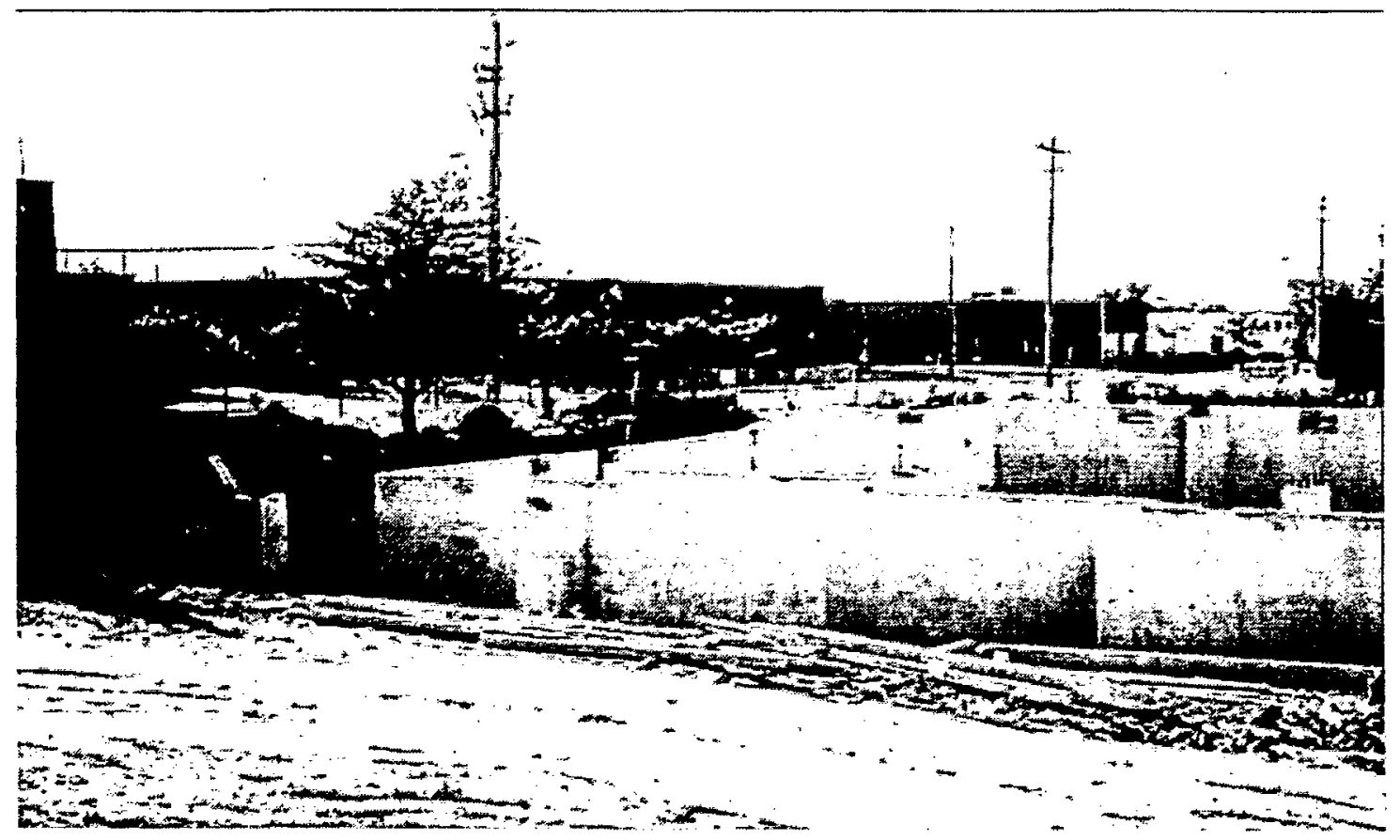

The height of the foundation walls was twelve feet from the basement floor. 


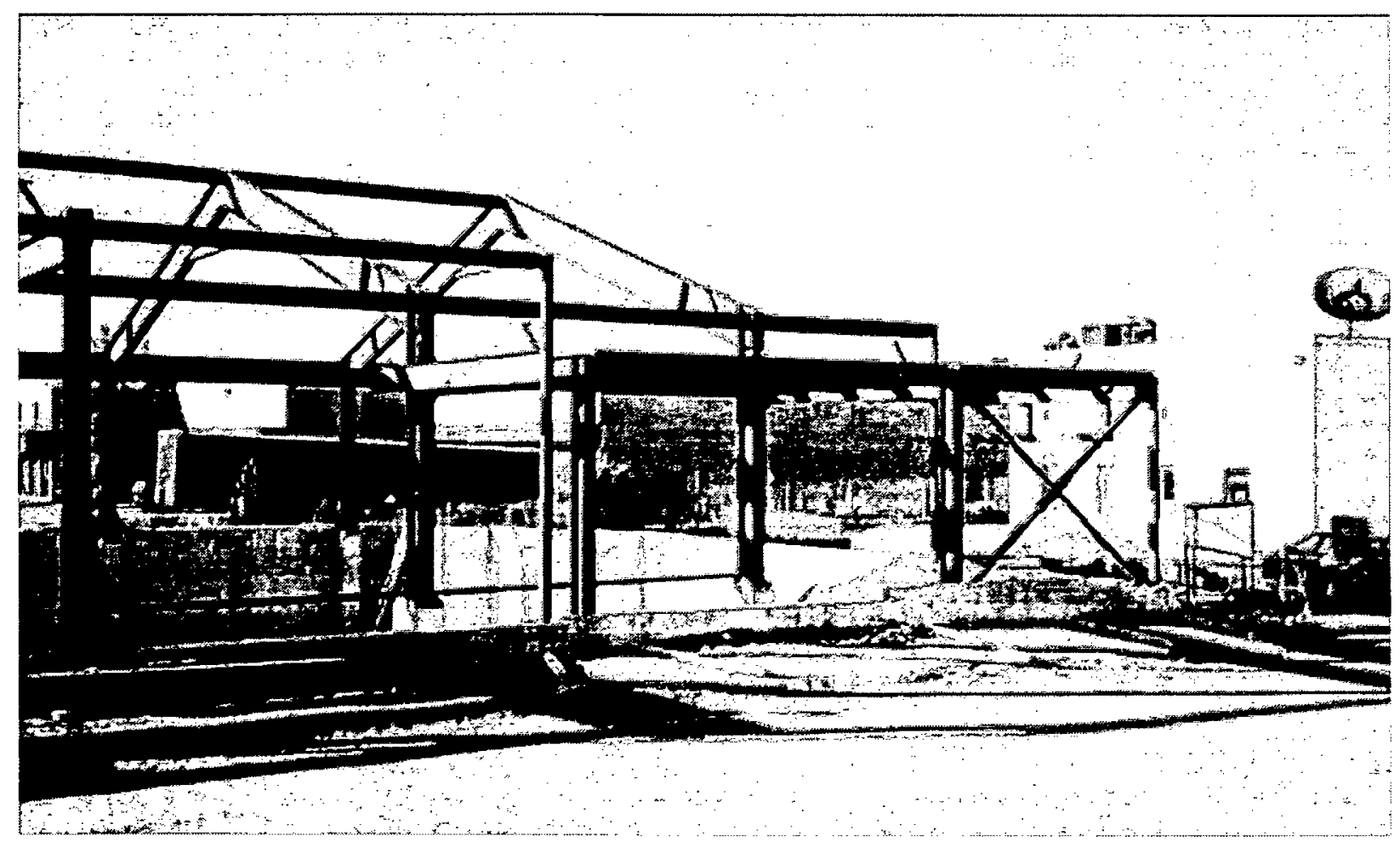

The structural steel frame of one section of the building 

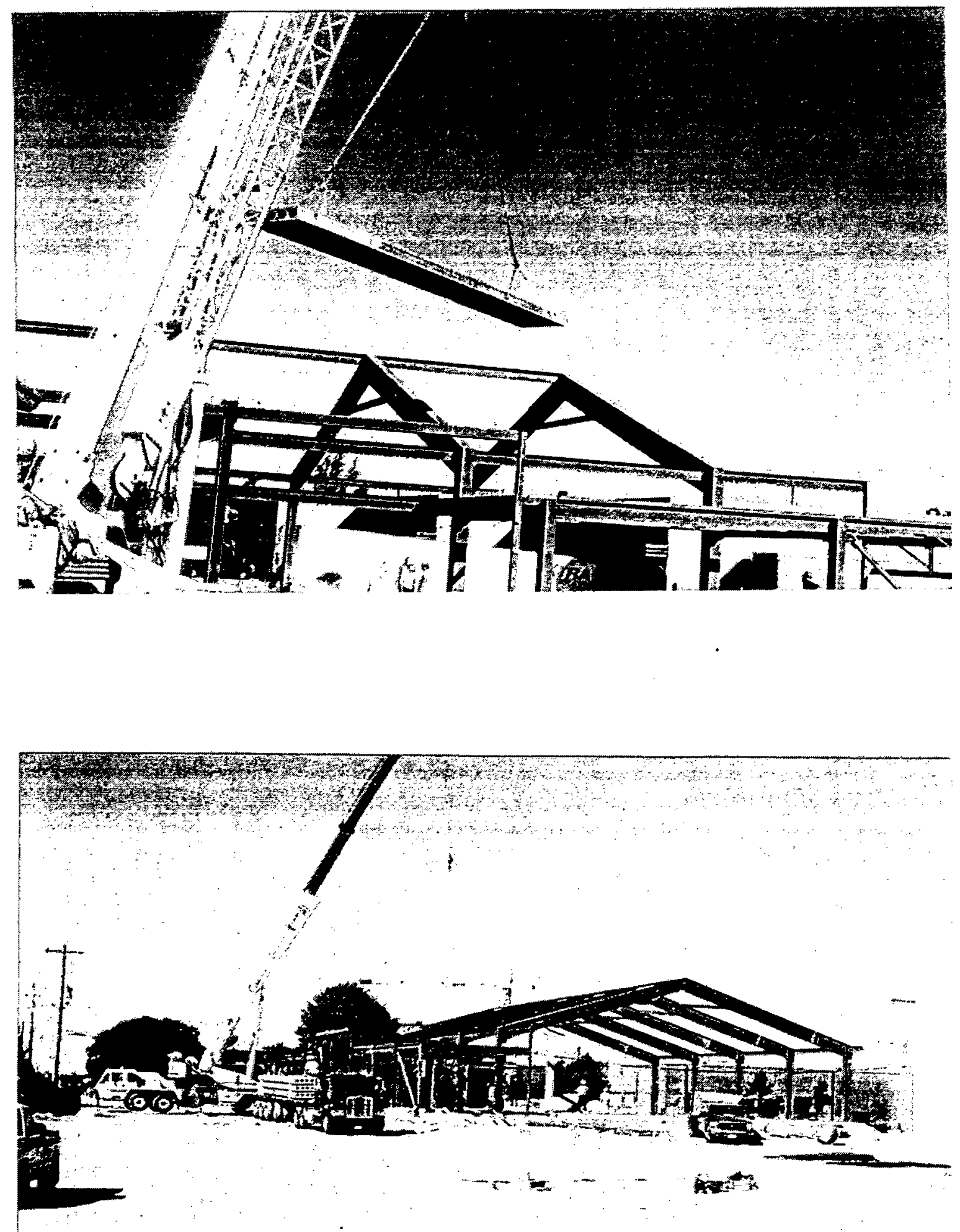

Above and Below: Floor installation-As the slabs are lifted from the transport trucks, work men guiding each piece into the designated place. 

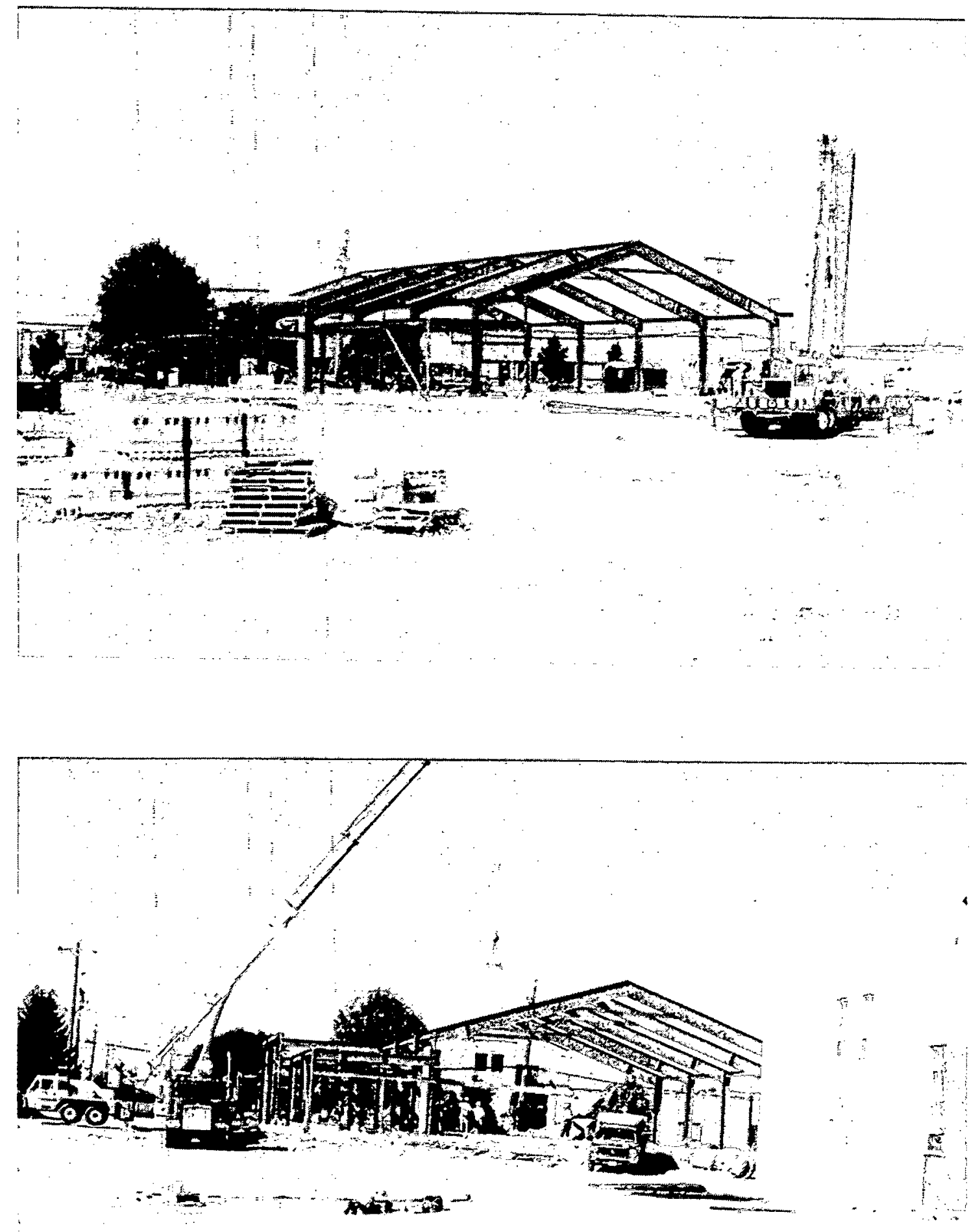

Above: Huge Cranes setting up for lifting the pre-cast slab into place for the main upper floor.

Below: Work men guiding the slabs as they are lowered through the roof. 

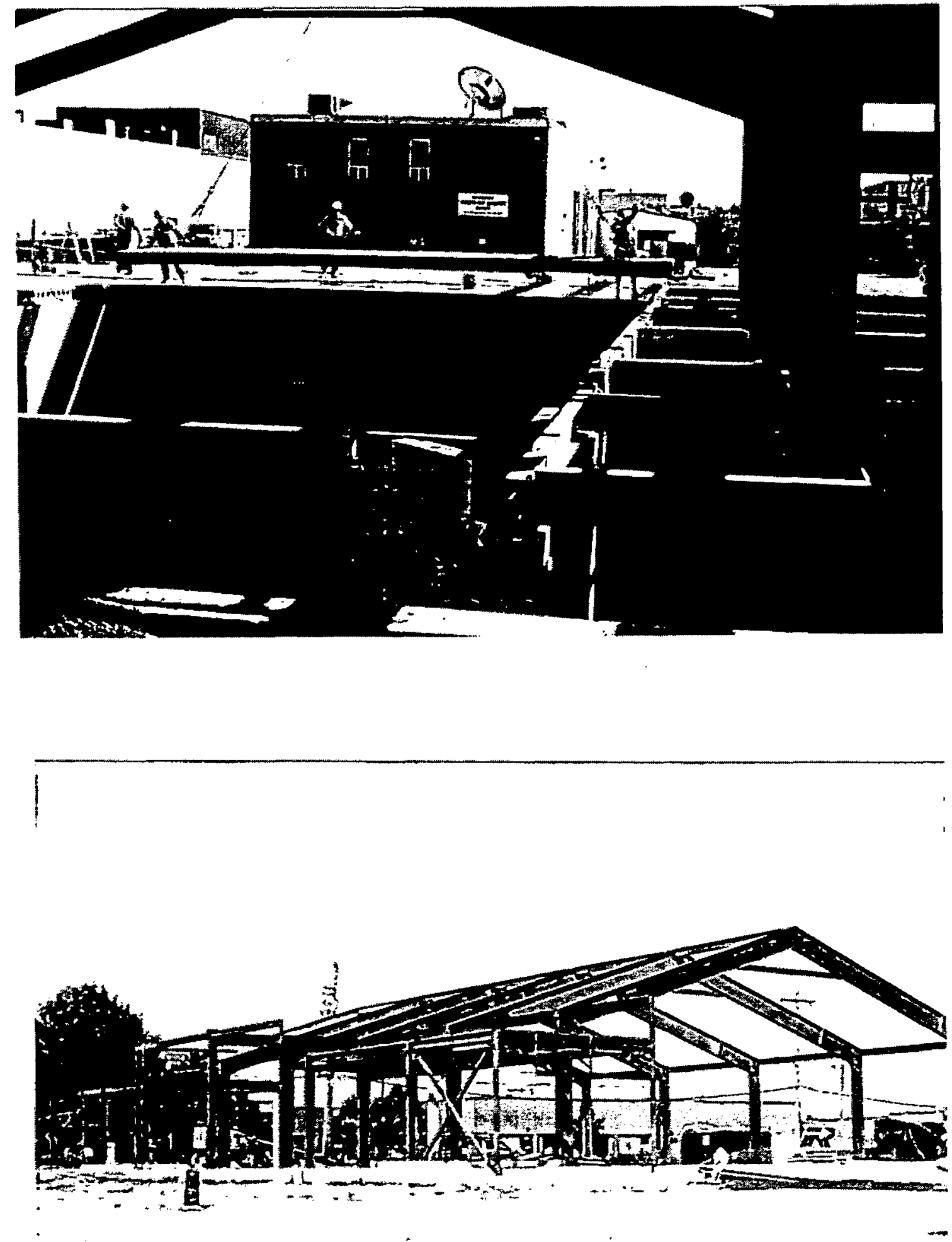

Above: Completing the installation for the upper floor
Below:
Steel frame of the building 


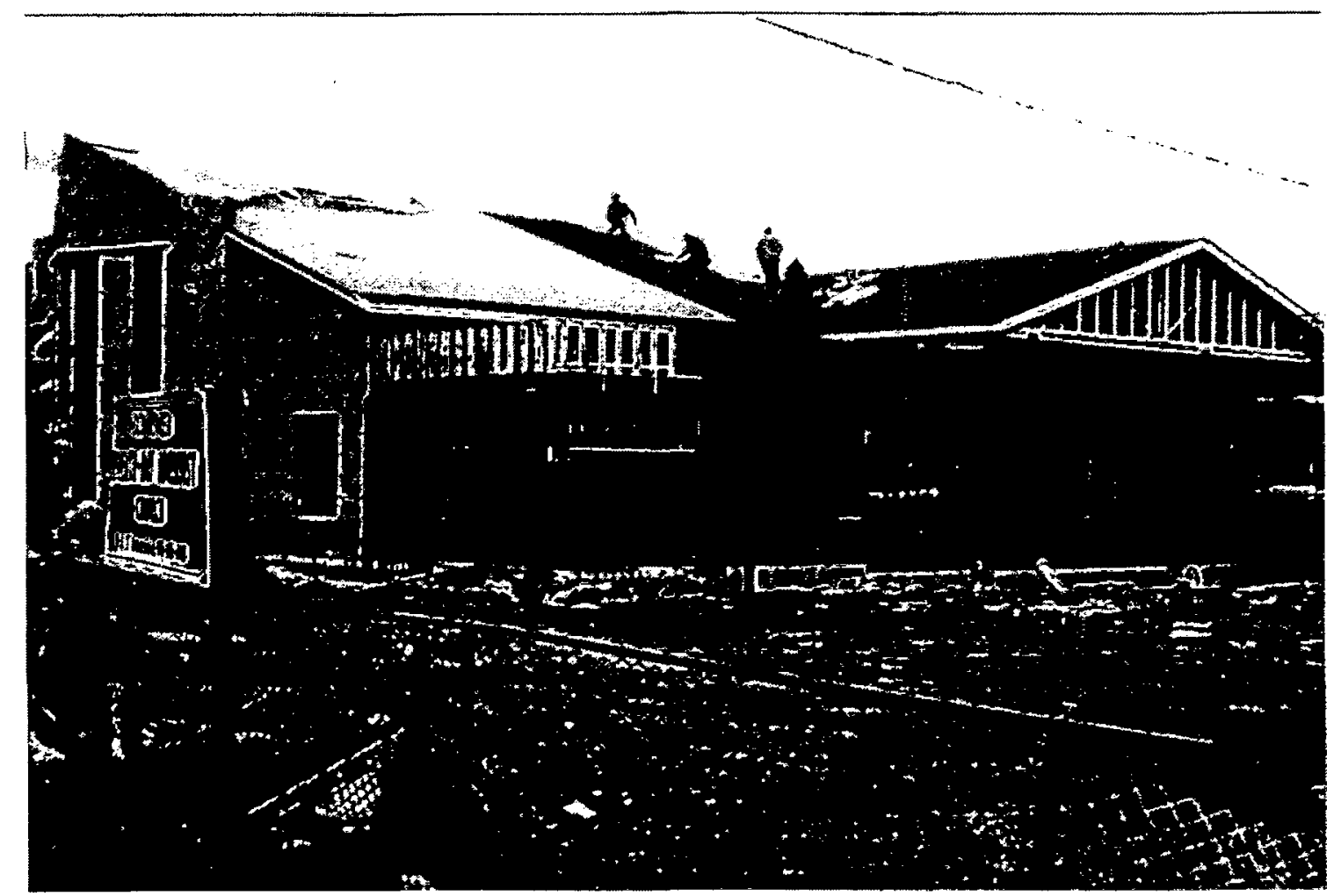

Workmen putting on the shingles on the roof of the church

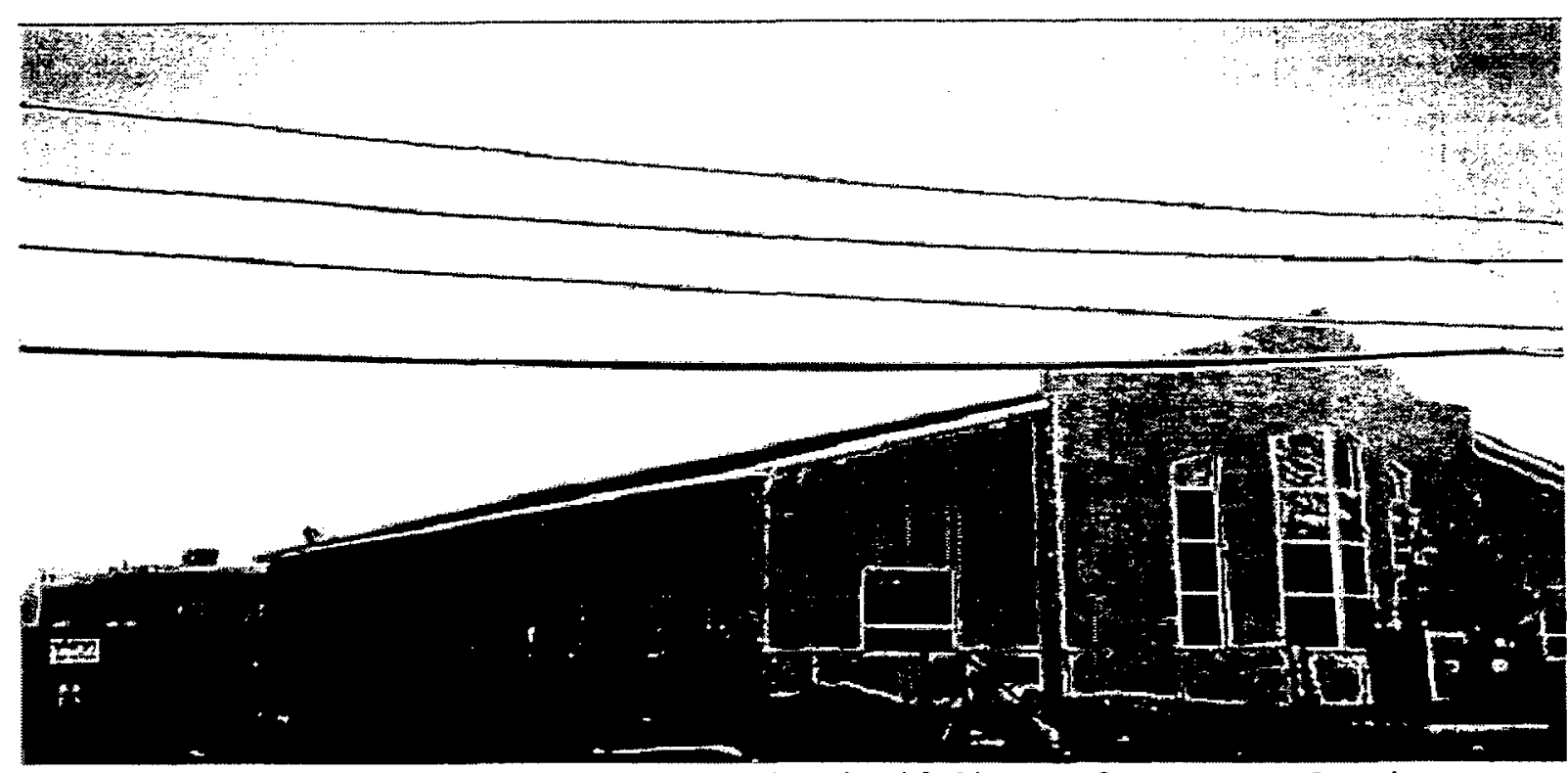

The North west corner of the building after completion 


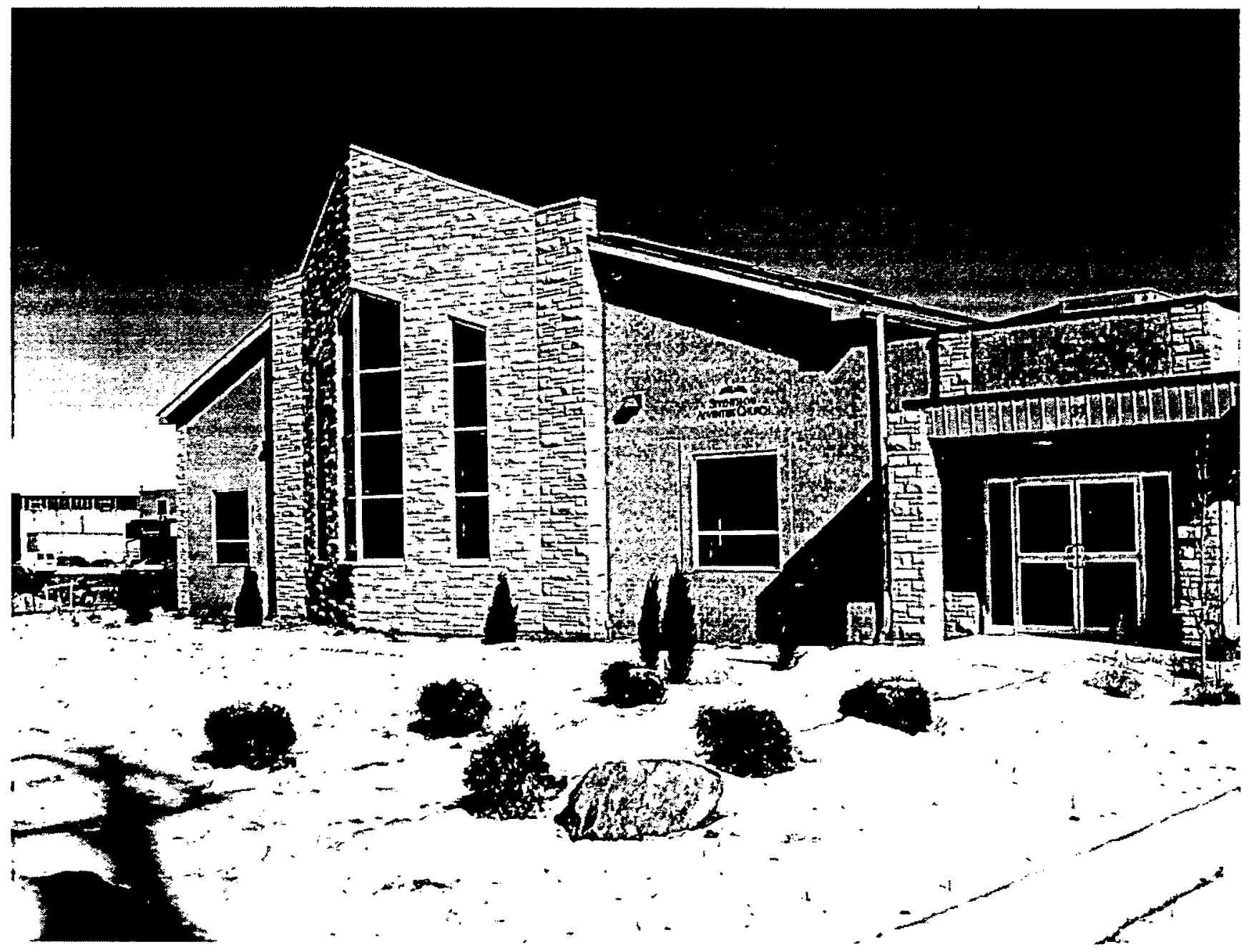

This is the front of the Church building

First Worship service was held on June 7, 2003 


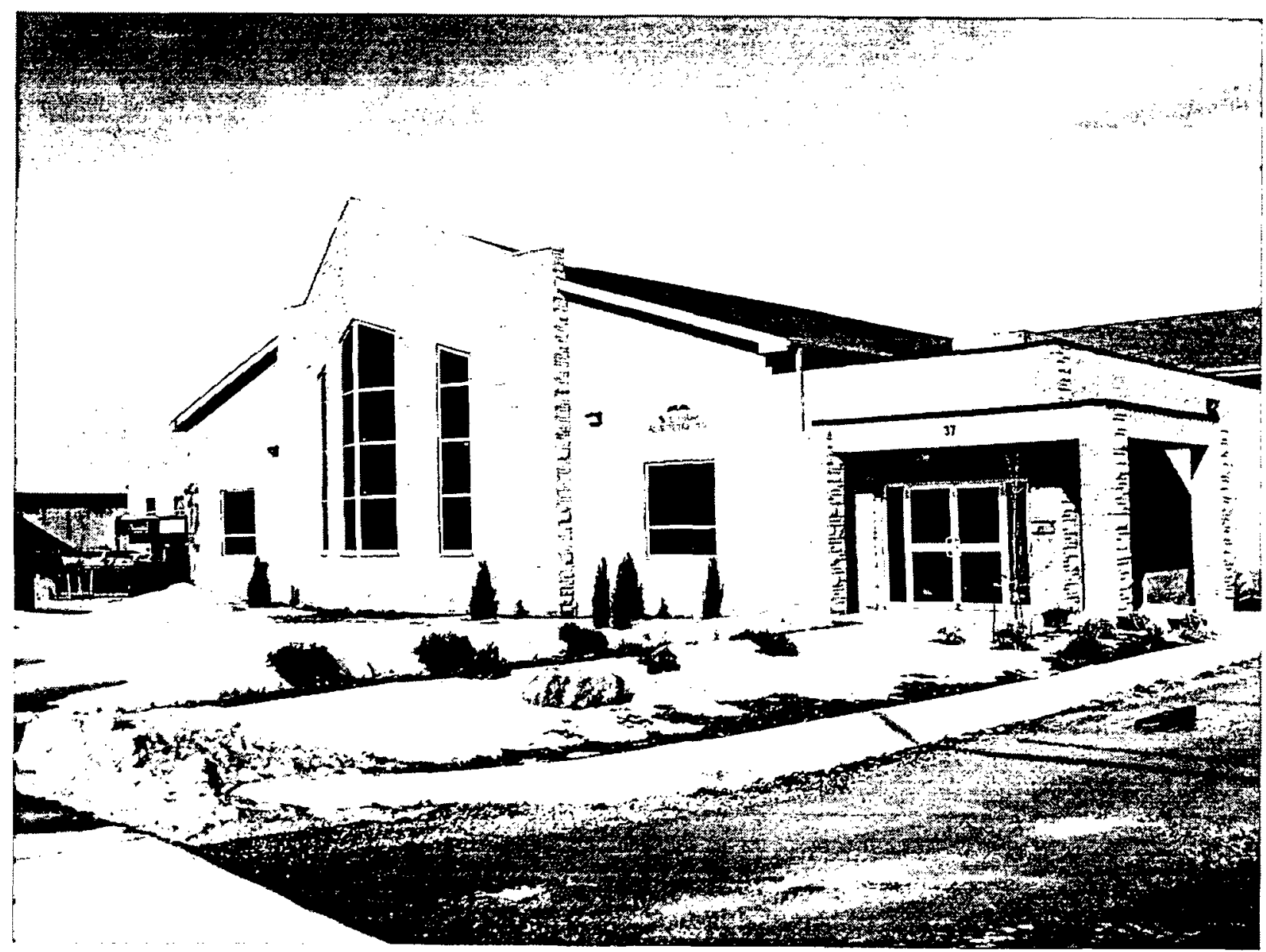

Front view of the new Sanctuary 


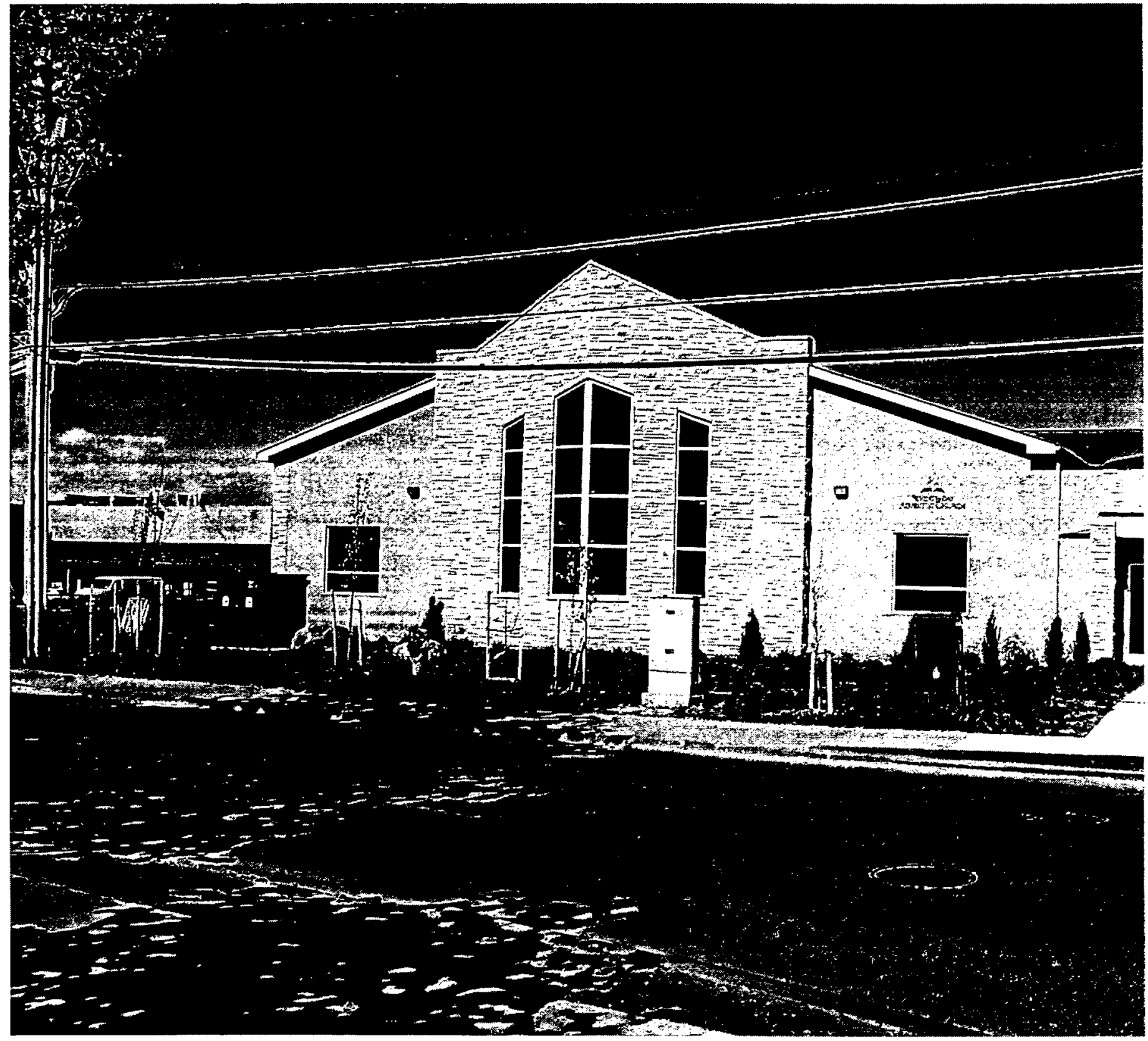




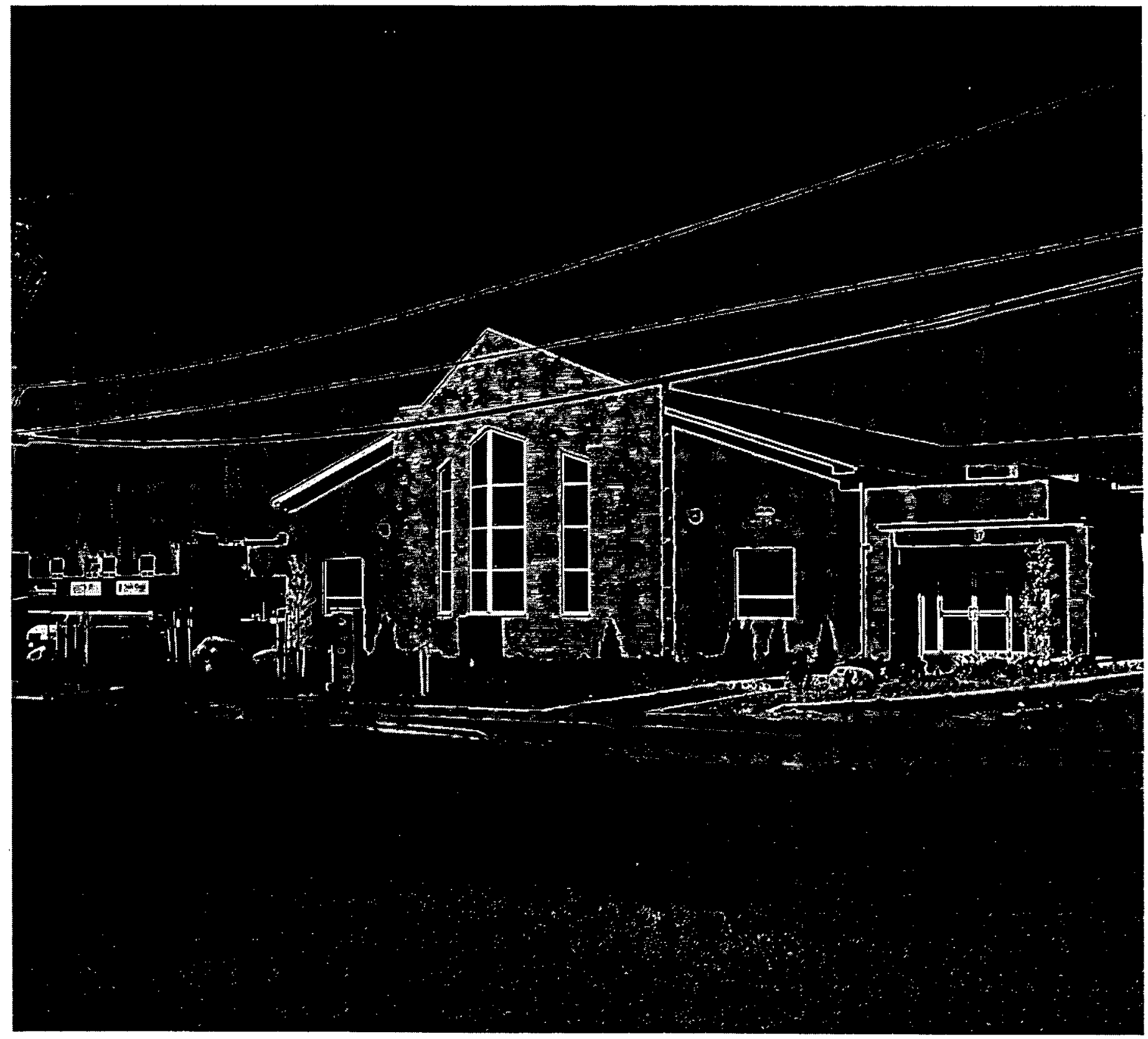


BIBLIOGRAPHY 


\section{BIBLIOGRAPHY}

"Acts." Seventh-day Adventist Bible Commentary. Edited by F. D. Nichol. Washington, DC: Review and Herald Publishing Association, 1953-1957. 6:1056.

Adams, Roy. The Sanctuary, Understanding the Heart of Adventist Theology. Hagerstown, MD: Review and Herald Publishing Association, 1993.

Anders, Max. Holman New Testament Commentary. Nashville, TN: Broadman and Holman Publishers, 2000.

Barclay, William. The Gospel of Matthew. Vol. 2. Philadelphia, PA: Westminister Press, 1976.

Barrie, Thomas. Spiritual Path, Sacred Place: Myth, Ritual, and Meaning in Architecture. Boston, MA: Shambhala, 1996.

Belknap, Ralph L. Effective Use of Church Space. Valley Forge, PA: Judson Press, 1978.

Bent, James A., and Albert Thumann. Project Management for Engineering and Construction. Lilburn, GA: Fairmont Press, 1994.

Bennett, Vicki. Sacred Space and Structural Style. Ottawa: University of Ottawa Press, 1997.

Board of Directors. March Minutes. Oshawa, ON: Ontario Conference of Seventh-day Adventist Church, 2001.

Boyd, Robert T. World's Bible Handbook. Iowa Falls, IA: Bible Publishers, 1991.

Brown, Colin. "Church." Dictionary of New Testament Theology. 3 vols. Grand Rapids, MI: Zondervan Publishing House, 1979.

Bowman, Ray, and Eddy Hall. When Not to Build: An Architect's Unconventional Wisdom for the Growing Church. Grand Rapids, MI: Baker Book House, 2000.

Burstein, David, and Frank Stasiowski. Project Management for Design Professional. New York: Whitney Library Design, 1991. 
Calian, Carnegie Samuel. Survival or Revival, Ten Keys to Church Vitality. Louisville, KY: Westminister John Knox Press, 1998.

Callahan, Kennon L. Building for Effective Mission, A Complete Guide for Congregations on Bricks and Mortar Issues. San Francisco, CA: Jossey-Press, 1995.

Chesnut, Robert A. Transforming the Mainline Church: Lessons in Change from Pittsburgh's Cathedral of Hope. Louisville: Geneva Press, 2000.

City of Toronto, Urban Planning and Development Services. Toronto: City Planning, Policy, and Research, 2003.

Cleland, David I. Project Management Strategic Design and Implementation. Boston, MA: McGraw Hill Publishers, 1994.

Cotter, David W. Genesis. Collegeville, MN: Liturgical Press, 2003.

Conference Directory Statistics: 1994 \& 2000. Oshawa, Ontario: The Ontario Conference of Seventh-day Adventists.

Covey, Stephen R. Principle-Centered Leadership. New York: Simon \& Schuster Publishers, 1992.

Covey, Stephen R., A. Roger Merrill, and Rebecca R. Merrill. First Things First, to Live, to Learn, to Leave a Legacy. New York: Simon and Schuster, 1994.

Davidson, Richard M. Typology in Scripture. Berrien Springs, MI: Andrews University Press, 1981.

Dale, Robert D. Leadership for a Changing Church: Charting the Shape of the River. Nashville, TN: Abingdon Press, 1998.

Dobson, Paul, and Ken Starkey. The Strategic Management Blueprint. London: Blackwell Publishers, 1993.

“Downsview Seventh-day Adventist Church Clerk's Report: 1979." Downsview Seventh-day Adventist Church, Toronto, Canada, 1979.

“Downsview Seventh-day Adventist Church Clerk's Report: 1984." Downsview Seventh-day Adventist Church, Toronto, Canada, 1984.

Downsview Seventh-day Adventist Church Minutes, Church Building Committee, June 14, 1988. Toronto, Ontario.

“Exodus." SDA Bible Commentary. Edited by F.D. Nichol. Washington, DC: Review and Herald Publishing Assn., 1953-1957. 1:713 
Exell, Joseph S. The Biblical Illustrator. Grand Rapids, MI: Baker Book House, 1954.

Field, Mike, and Laurie Keller. Project Management. London: International Thomson Business Press, 1998.

Firth, Robert E. Guidelines for Committee and Board Members. Washington, DC:

Review and Herald Publishing Association, 1973.

Fretheim, Terrence E. "Exodus." Interpretation, A Bible Commentary for Teaching and Preaching. Louisville, TN: John Knox Press, 1991.

Gaebelein, Frank E. The Expositor's Bible Commentary. Grand Rapids, MI: Zondervan Publishing Association, 1990.

"Genesis." Seventh-day Adventist Bible Commentary. Edited by F. D. Nichol.

Washington, DC: Review and Herald Publishing Association, 1953-1957. 1:257.

"Genesis." Bible Student Commentary. Edited by G. Charles Alder. Grand Rapids, MI: Zondervan Publishing House, 1981.

Guthrie, D. The Eerdmans Bible Commentary. Grand Rapids, MI: Wm. B. Eerdmans Publishing Company, 1970.

Hanna, Jeffrey. Safe and Secure: The Alban Guide to Protecting Your Congregation. Bethesda, MD: Alban Institute Publication, 1999.

Hanna, J. H. What Is a Good Project Manager? Houston, TX: Gulf Publishing Company, 1986.

Harris, Ralph W., Stanley M. Harton, and Gayle Gerrity Seaver. The New Testament Study Bible. Springfield, MO: Complete Bible Library, 1989.

Hill, Andrew E. The NIV Application Commentary. Grand Rapids, MI: Zondervan Publishing House, 2003.

Janzen, Waldemar. "Exodus." Believers Church Bible Commentary. Waterloo, Ontario: Herald Press, 2000.

Jernigan, Jules Donald. Quest for the Rainbow: Basic Guidelines for Building Churches. Grand Rapids, MI: Baker Book House, 1975.

Kerridge, Arthur E., and Charles H. Vervalin. Engineering and Construction Project Management. Houston, TX: Gulf Publishing Company, 1986.

Huber, Evelyn M. Enlist, Train, Support Church Leaders. Valley Forge, PA: Judson Press, 1975. 
Lee, Harris W. Effective Church Leadership: A Practical Source Book. Minneapolis, MN: Augsburg Fortress, 1989.

Leupold, H. C. Exposition of Genesis. Grand Rapids, MI: Baker Book House, 1953.

“Leviticus." Seventh-day Adventist Bible Commentary. Edited by F. D. Nichol.

Washington, DC: Review and Herald Publishing Association, 1953-1957. 1:713.

Leas, Speed. The Ten Most Predictable Times of Conflict. Quoted in Marshall Shelley, Leading Your Church through Conflict and Reconciliation. Minneapolis, MN: Bethany House Publishers, 1997.

Malphurs, Aubrey. Advanced Strategic Planning: A New Model for Church and Ministry Leaders. Grand Rapids, MI: Bakers Books, 1999. . Being Leaders. Grand Rapids, MI: Bakers Books, 2003. . Planting Growing Churches for the $21^{\text {st }}$ Century. Grand Rapids, MI: Bakers Books, 1998. . Strategy 2000: Churches Making Disciples for the Next Millennium. Grand Rapids, MI: Kregel Resources, 1996.

"Matthew." Seventh-day Adventist Bible Commentary. Edited by F. D. Nichol. Washington, DC: Review and Herald Publishing Association, 1953-1957. 5:430.

Mattson, Ralph T. Visions of Grandeur, Leadership That Creates Positive Change. Chicago: Moody Press, 1994.

Medicare: A Strategy for Quality Assurance. 2 vols. Washington, DC: National Academy Press, 1990.

Mitchell, Oyeman, pastor of the Hope Seventh-day Adventist Church in Toronto. Interview by author, 20 August 2004, Toronto. In the hands of author, Toronto, Canada.

Morris, H. Jack. "Managing Conflict in the Church, 2001." Ministry, May 2001, 5-7.

Evangelical Lutheran-Roman Catholic Dialogue, Quest for Visible Unity. Washington, DC: Lutheran-Catholic Committee, 1998.

Olsen, Charles M. Cultivating Religious Growth Groups. Philadelphia, PA: Westminister Press, 1984.

Ontario Conference of Seventh-day Adventists (Oshawa, Ontario). Minutes of Board of Directors, 38-2001, March 18, 2001. 
Nelson, Alan, and Stan Toler. The Five Secrets of Becoming a Leader. Ventura, CA: Regal Books, 2002.

Nelson, Alan E. Leading Your Ministry. Nashville, TN: Abingdon Press, 1996.

Penner, Donald. The Project Manager's Survival Guide: The Handbook for Real-World Project Management. Columbus, OH: Battelle Press, 1994.

"Psalms." Seventh-day Adventist Bible Commentary. Edited by F. D. Nichol. Washington, DC: Review and Herald Publishing Association, 1953-1957. 3:902.

Rainer, Thom. High Expectations: The Remarkable Secret for Keeping People in Your Church. Nashville, TN: Broadman and Holman Publishers, 1999.

Red, David. Rational Design. New York: Vantage Press, 1990.

Rosenau, Milton D., Jr. Project Management for Engineers. New York: Van Nostrand Reinhold Company, 1984.

Ryrie, Charles Caldwell. The Ryrie Study Bible. Chicago, IL: Moody Press, 1986.

Schaller, Lyle. The Multiple Staff in the Larger Church. Nashville, TN: Abingdon Press, 1980.

Seventh-day Adventist Minister's Handbook. Silver Spring, MD: Ministerial Association of General Conference of Seventh-day Adventists, 1997.

Seventh-day Adventist Church, Recommendations for Church Planners. Washington, DC: Review and Herald Publishing Association, 1991.

Seventh-day Adventist Church Planning, Church and School Buildings. Washington, DC: Review and Herald Publishing Association, 1953.

Schnurr, Monsignor Dennis M. "Keep Your Hand on the Plough." In Committee on African American Catholics National Conference of Bishops. Washington, DC: United States Catholic Conference, 1996.

. "Evangelical Lutheran-Roman Catholic Dialogue, Quest for Visible Unity, Lutheran-Roman Catholic Committee." 1998.

Spence, H.D.M. The Pulpit Commentary. Grand Rapids, MI: Wm. B. Eerdmans Publishing Association, 1961.

Statistics Canada. 2001 Census.

http://www.toronto.ca/wards2000/pdf/wardprofiles_08.pdf. 
Stitt, Fred. Designing Building That Works. New York: McGraw-Hill Book Company, 1985.

Tennyson, Mack. Making Committees Work. Hagerstown, MD: Ministerial Association of General Conference of Seventh-day Adventist Church, 1984.

. Church Finances for People Who Count. Silver Spring, MD: Ministerial Association, General Conference of Seventh-day Adventists, 1984.

Wagner, C. Peter. Church Planting for a Greater Harvest: A Comprehensive Guide. Ventura, CA: Regal Books, 1990.

Your Spiritual Gifts Can Help Your Church Grow. Ventura, CA: Regal Books, 1994.

Wainwright, Geoffrey. Doxology-The Praise of God in Worship, Doctrine, and Life. New Press, 1980.

Waltke, Bruce K., and Cathy J. Fredricks. Genesis. Grand Rapids, MI: Zonderman Publishing, 2001.

Wallenkampf, Arnold V., and Richard Lesher, eds. The Sanctuary and the Atonement: Biblical, Historical and Theological Studies. Washington, DC: Review and Herald Publishing Association, 1981.

Warren, Rick. The Purpose Driven Church: Growth without Compromising Your Message and Mission. Grand Rapids, MI: Zondervan Publishing House, 1995.

White, Ellen G. “An Appeal.” Australian Union Record, 1 January 1900, par. 31.

. "Building a House for God." Manuscript 23, 1886. Ellen G. White Research Center, Andrews University, Berrien Springs, MI.

. Christian Service. Washington, DC: Review and Herald Publishing Association, 1983.

. Counsels on Sabbath School Work. Washington, DC: Review and Herald Publishing Association, 1938.

Counsels on Stewardship. Washington, DC: Review and Herald Publishing Association, 1940. 1940.

Desire of Ages. Mountain View, CA: Pacific Press Publishing Association,

. Early Writings. Washington, DC: Review and Herald Publishing Association, 1945. 
. Education. Boise, ID: Pacific Press Publishing Association, 1903. 1946.

Evangelism. Washington, DC: Review and Herald Publishing Association, . Gospel Workers. Washington, DC: Review and Herald Publishing Association, 1948.

Great Controversy. Washington, DC: Review and Herald, Publishing Association, 1950.

. “A Lesson in Liberality." Pacific Union Recorder, 14 November 1907, 2.

. Ministry of Healing. Mountain View, CA: Pacific Press Publishing Association, 1909.

. MS 23, 1866. Ellen G. White Research Center, Andrews University, Berrien Springs, MI.

. MS 49, Ellen G. White Research Center, Andrews University, Berrien Springs, MI.

. MS 53, 1903. Ellen G. White Research Center, Andrews University, Berrien Springs, MI.

. MS 69, 1900. Ellen G. White Research Center, Andrews University, Berrien Springs, MI.

. The Needs of the Cause in Australia. Ellen G. White Research Center, Andrews University, Berrien Springs, MI.

. Patriarchs and Prophets. Mountain View, CA: Pacific Press Publishing Association, 1958.

. Prophets and Kings. Mountain View, CA: Pacific Press Publishing Association, 1943.

. Reflecting Christ. Washington, DC: Review and Herald Publishing Association, 1985.

. Spirit of Prophecy. Vol. 1. Washington, DC: Review and Herald Publishing Association, 1969.

. "Systematic Benevolence." Second Advent Review and Sabbath Herald, January 1,1875 , par. 9 . 
Testimonies to the Church. 9 vols. Mountain View, CA: Pacific Publishing Association, 1948.

to Brethren Greggs and Howe, 23 August, 1898, Letter G. 65, 1898. Ellen G. White Research Center. Andrews University, Berrien Springs, MI.

to Dear Brethren and Sisters in Washington, June 6, 1909, Letter B 94a, 1909. Quoted in Eduardo Aurita, "Towards a Theology of the Seventh-day Adventist Meeting Place, with a Study of Practical Implications and Applications Thereof." Project Report, Andrews University, Berrien Springs, MI, 1984, 84.

to Elder J. D. Rice, 11 December 1908, Letter R 342, 1908. Ellen White Research Center, Berrien Springs, MI.

to Members of Oakland Church, 18 January 1907, Letter 10, 1907. Ellen G. White Research Center, Andrews University, Berrien Springs, MI.

. "To Those Making Large Gifts to the Cause of Present Truth." The Northern Union Recorder, 16 April 1907, 3.

. "The Use of Tithe." Echoes from the Field, 21 June 1905, par. 2.

3.

. "The Work at Fresno, California." Review and Sabbath Herald, 19 June 1888,

. "Work in Christ's Line." Review and Herald, 24 June 1902, 8-9.

White, James F., and Susan J. White. Church Architecture: Building and Renovating for Christian Worship. Akron, OH: OSL Publication, 2002.

Wilson, Marlene. How to Mobilize Church Volunteers. Minneapolis, MN: Augsburg Publishing House, 1983. 
VITA 
VITA

KENNETH R. CAMPBELL

\section{EDUCATION}

M.Div., Andrews University, Berrien Springs, Michigan, 1981

B.Th., Northern Caribbean University, Jamaica, W.I., 1975

\section{WORK EXPERIENCE}

Pastor, Downsview Seventh-day Adventist Church, Toronto, Ontario (1994-present)

Pastor, Bethel Seventh-day Adventist Church, Toronto, Ontario (1990-1994)

Pastor, Hamilton East Seventh-day Adventist Church, milton, Ontario (1986-1990)

Assoc. Pastor, Perth Seventh-day Adventist Church, Toronto, Ontario (1984-1986)

Literature Evangelist, Ontario Conference of Seventh-day Adventist Church (1981-1984)

Literature Evangelist, Manitoba-Sask Conference of Seventh-day Adventist Church (1977-1978)

Pastor, West Jamaica Conference of Seventh-day Adventist Church, Montego Bay, Jamaica (1975-1978)

\section{ORDINATION}

Seventh-day Adventist Church, 1987

\section{INITIATIVES}

Building of the Downsview Seventh-day Adventist Church, Toronto (1995-2003)

Church growth from 240 - 579 (1994-2004)

Organized four Tent Evangelistic Series, resulting in 425 Baptisms (1996-2003)

Conducts vibrant worship service

Energetic in teaching and training lay persons for soul winning.

Conducts Pastor's Bible Class. 